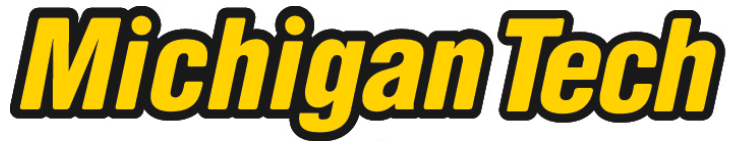 \\ Michigan Technological University Create the Future Digital Commons @ Michigan Tech
}

Dissertations, Master's Theses and Master's Reports - Open

Dissertations, Master's Theses and Master's

Reports

2011

Improving sixth grade student knowledge of ecology using fish rearing and release as a real-world context

Erich Ziegler

Michigan Technological University

Follow this and additional works at: https://digitalcommons.mtu.edu/etds

Part of the Science and Mathematics Education Commons

Copyright 2011 Erich Ziegler

\section{Recommended Citation}

Ziegler, Erich, "Improving sixth grade student knowledge of ecology using fish rearing and release as a real-world context ", Master's report, Michigan Technological University, 2011.

https://doi.org/10.37099/mtu.dc.etds/531

Follow this and additional works at: https://digitalcommons.mtu.edu/etds

8 Part of the Science and Mathematics Education Commons 


\title{
IMPROVING SIXTH GRADE STUDENT KNOWLEDGE OF ECOLOGY USING FISH REARING AND RELEASE AS A REAL-WORLD CONTEXT
}

\author{
By
}

Erich Ziegler

\begin{abstract}
A REPORT
Submitted in partial fulfillment of the requirements for the degree of MASTER OF SCIENCE

(Applied Science Education)
\end{abstract}

MICHIGAN TECHNOLOGICAL UNIVERSITY

2011

(C) 2011 Erich Ziegler 
This page deliberately blank 
This report, "Improving Sixth Grade Student Knowledge of Ecology Using Fish Rearing and Release as a Real-world Context," is hereby approved in partial fulfillment of the requirements for the degree of: MASTER OF SCIENCE IN APPLIED SCIENCE EDUCATION.

Department Of Cognitive And Learning Sciences

Signatures:

\begin{tabular}{cl} 
Report Advisor & William Yarroch \\
Committee Member & \\
Committee Member & \\
Dedmon Hungwe \\
Date & Bradley Baltensperger \\
\hline
\end{tabular}


This page deliberately blank 


\section{Table of Contents}

LIST OF TABLES ................................................................................................................................... VII

LIST OF FIGURES ........................................................................................................................................ IX

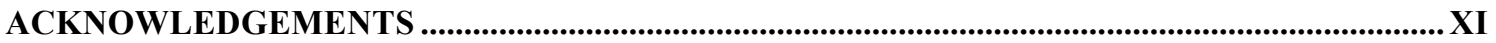

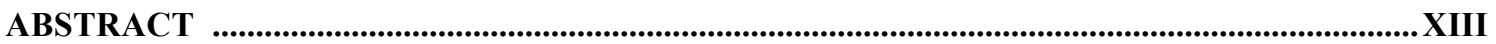

CHAPTER 1 - AREA OF FOCUS STATEMENT ....................................................................................1

INTRODUCTION

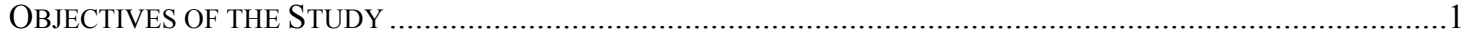

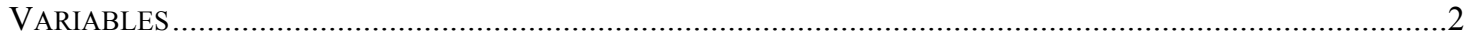

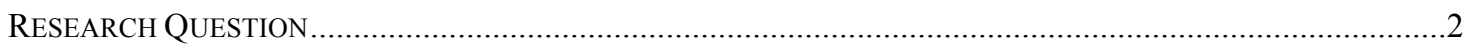

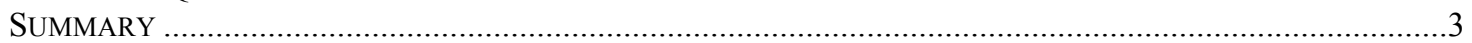

CHAPTER 2 - LITERATURE REVIEW ...................................................................................................5

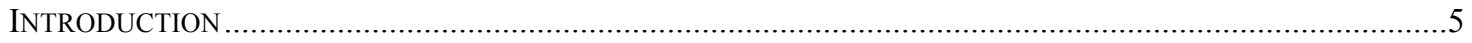

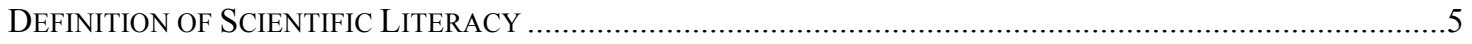

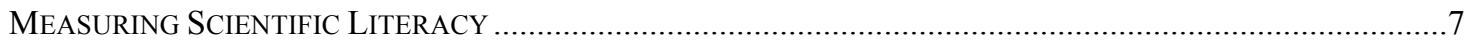

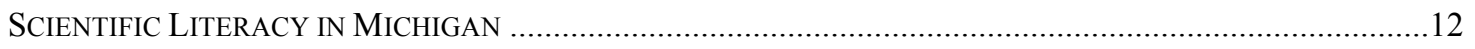

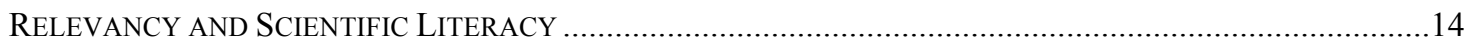

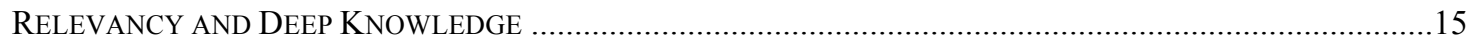

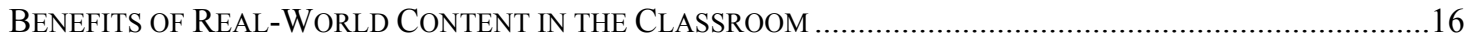

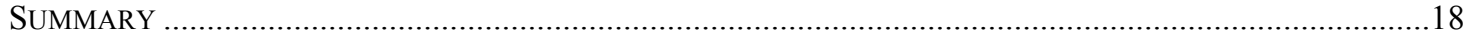

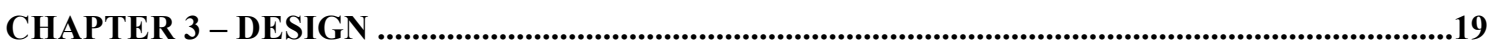

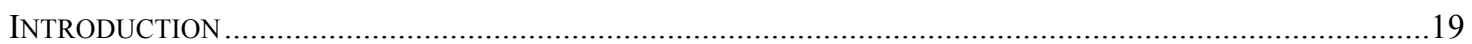

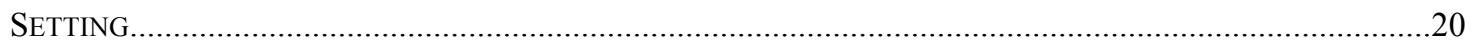

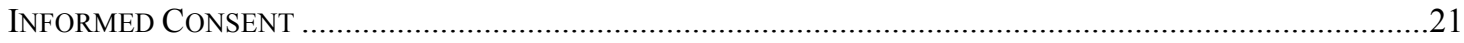

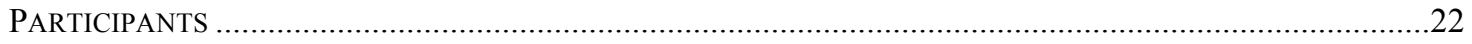

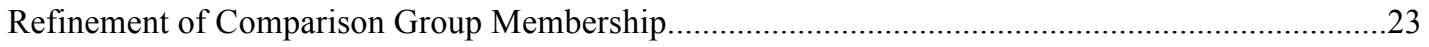

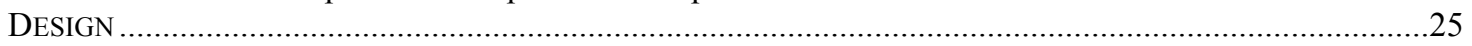

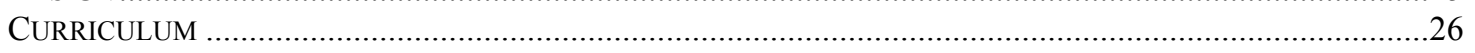

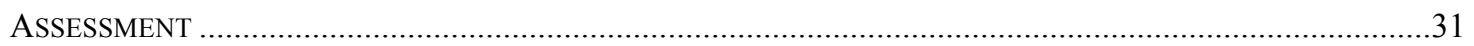

CHAPTER 4 - DATA ..............................................................................................................................35

SCORING AND ItEM ANALYSIS Of THE MultiPle Choice PART OF POST-TEST ........................................35

SCORING AND ITEM ANALYSIS OF THE CONSTRUCTED RESPONSE PART OF POST-TEST ..............................40

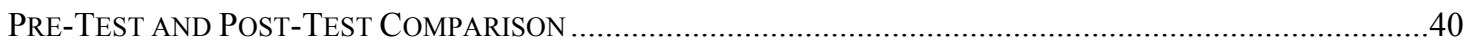

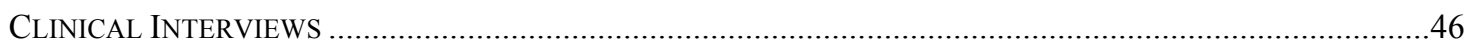

CHAPTER 5 - CONCLUSION .........................................................................................................53

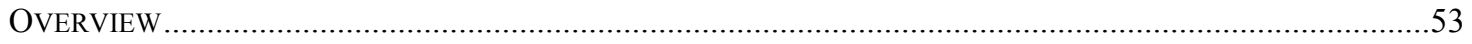

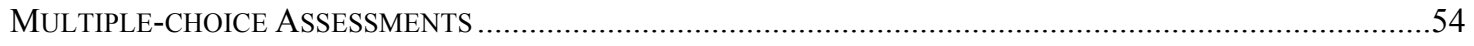

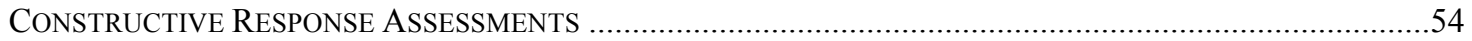

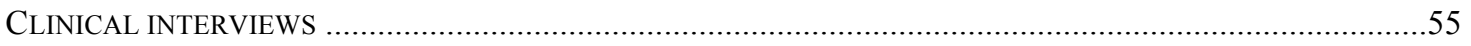

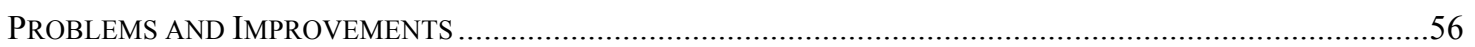

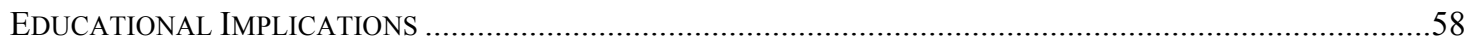




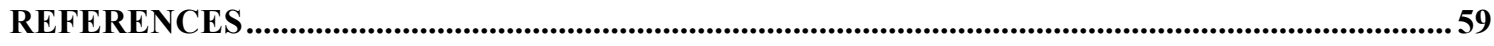

APPENDIX A. PRE- AND POST-TEST AND ANSWER KEY .......................................................65

APPENDIX B. ECOSYSTEMS UNIT OBJECTIVES AND VOCABULARY ................................ 77

APPENDIX C. PRODUCERS, CONSUMERS, AND DECOMPOSERS SUBUNIT RESOURCES

APPENDIX D. INTERACTIONS OF ORGANISMS SUBUNIT RESOURCES ............................83

APPENDIX E. RELATIONSHIPS OF ORGANISMS SUBUNIT RESOURCES ............................999

APPENDIX F. ABIOTIC AND BIOTIC FACTORS SUBUNIT RESOURCES ..............................111

APPENDIX G. ENVIRONMENTAL IMPACTS OF ORGANISMS SUBUNIT RESOURCES..... 113

APPENDIX H. STOCKING PERMIT FROM MI DNR ...........................................................123

APPENDIX I. ECOPOSTER GROUP ACTIVITY RUBRIC ..................................................125

APPENDIX J. PRE- AND POST-TEST OBJECTIVE QUESTIONS RUBRIC ............................... 131

APPENDIX K. STUDENT POST-TEST ESSAYS AND RUBRICS ........................................... 133

APPENDIX L. CLINICAL INTERVIEWS (VERBATIM) .......................................................... 139

APPENDIX M. PHOTOGRAPHS (TAKEN BY ZIEGLER) OF TROUT SETUP IN CLASSROOM AND TROUT RELEASE IN LOCAL LAKE..................................................... 163

APPENDIX N. INSTITUTIONAL REVIEW BOARD FORMS ................................................... 165 


\section{List of Tables}

TABLE 1. SIXTH GRADE LEVEL CONTENT EXPECTATIONS AND MICHIGAN CURRICULUM FRAMEWORK USED FOR THE ECOLOGY UNIT .......................20

TABLE 2. FOREST PARK SIXTH GRADE STUDENT DEMOGRAPHICS ...............................21

TABLE 3. COMPARISON OF THE SECOND AND SEVENTH HOUR CLASSES USED IN THE STUDY

TABLE 4. COMPARISON OF THE SECOND AND SEVENTH PERIOD CLASSES USING ONLY THE MATCHED EXPERIMENTAL/CONTROL SUBJECTS...........................25

TABLE 5. COMPARISON OF THE CURRICULUM BETWEEN THE CONTROL AND EXPERIMENTAL CLASS ................................................................................................26

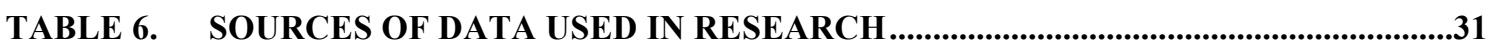

TABLE 7. PRE-TEST/POST-TEST ITEM TABLE OF SPECIFICATIONS ...................................34

TABLE 8. ITEM DIFFICULTY (MULTIPLE-CHOICE POST-TEST) ..........................................36

TABLE 9. ITEM DISCRIMINATION (MULTIPLE-CHOICE POST-TEST) ................................38

TABLE 10. STUDENTS PRE-TEST AND POST-TEST MULTIPLE-CHOICE SCORE ...............41

TABLE 11. STUDENTS PRE-TEST AND POST-TEST CONSTRUCTED RESPONSE TEST

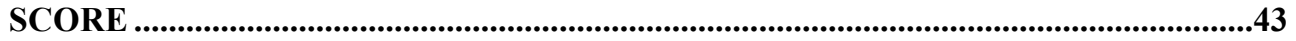

TABLE 12. PRE-TEST AND POST-TEST PERCENT GAIN BY MATCHED EXPERIMENTAL/CONTROL SUBJECTS.......................................................................45

TABLE 13. SUMMARY OF CLINICAL INTERVIEW DATA ..................................................46 
This page deliberately blank 


\section{List of Figures}

FIGURE 1. CONTROL GROUP INDIVIDUAL STUDENT PRETEST-POSTTEST CHANGE (MULTIPLE-CHOICE TEST).

FIGURE 2. EXPERIMENTAL GROUP INDIVIDUAL STUDENT PRETEST-POSTTEST CHANGE (MULTIPLE-CHOICE TEST).................................................................42

FIGURE 3. CONTROL GROUP INDIVIDUAL STUDENT PRETEST-POSTTEST CHANGE

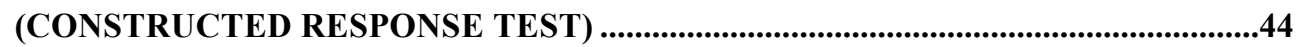

FIGURE 4. EXPERIMENTAL GROUP INDIVIDUAL STUDENT PRETEST-POSTTEST

CHANGE (CONSTRUCTED RESPONSE TEST).............................................................44 
This page deliberately blank 


\section{Acknowledgements}

There are many people that helped make this research project possible. I would like to personally thank them for their support.

Thank you to my advisor Dr. William Yarroch. His guidance and advice throughout the process was greatly appreciated. I have learned a lot from you.

Thank you to my colleagues at Forest Park Schools. It is an honor to be giving back to the school that gave me so much.

Thank you to my students involved in this project. It is because of you that I am so passionate for the field of education.

Thank you to my family. My father always told me to do my best; my mother always told me to keep a positive attitude. This is the greatest of advice.

Thank you to my wife Chandra and daughter Emma. Your love and support help make me who I am. 
This page deliberately blank 


\begin{abstract}
This research project measured the effects of real-world content in a science classroom by determining change (deep knowledge of life science content, including ecosystems from $M D E-$ Grade Level Content Expectations) in a subset of students (6 ${ }^{\text {th }}$ Grade Science) that may result from the addition of curriculum (real-world content of rearing trout in the classroom). Data showed large gains from the pre-test to post-test in students from both the experimental and control groups. The ecology unit with the implementation of real-world content [trout] was even more successful, and improved students' deep knowledge of ecosystem content from Michigan's Department of Education Grade Level Content Expectations. The gains by the experimental group on the constructed response section of the test, which included higher cognitive level items, were significant. Clinical interviews after the post-test confirmed increases in deep knowledge of ecosystem concepts in the experimental group, by revealing that a sample of experimental group students had a better grasp of important ecology concepts as compared to a sample of control group students.
\end{abstract}


This page deliberately blank 


\section{Chapter 1 - Area of Focus Statement}

\section{Introduction}

According to the Michigan Standards for Teaching and Learning, teachers should "make connections between substantive knowledge and either public problems or personal experiences" (MDE, 2007). In order to make this happen, educators must focus on relevant material, which is fundamental to the acquisition of scientific literacy. In addition to the national and state standards that today's educator is dependent on, the use of relevant applications and real-world content have been shown to be a valuable addition to a teacher's "toolbox" of research-based strategies. The time-tested objective of scientific literacy is still vital to a successful classroom, having been described as the “desired outcome of science education" (DeBoer, 2000). Ensuring that students are scientifically literate and prepared for the world outside of my classroom is one of my most important goals as an educator.

\section{Objectives of the Study}

I would like to measure the effects of "real-world content" in my science classes, looking specifically at improvement in deep knowledge of a topic. If the effects on these aspects are positive, there should also be improvements on standardized tests. Therefore, the purpose of this study is to measure change (deep knowledge of life science content, including ecosystems from $M D E$ - Grade Level Content Expectations) in a subset of 
students $\left(6^{\text {th }}\right.$ Grade Science) that may result from the addition of curriculum (real-world content of rearing trout in the classroom).

\section{Variables}

The following variables must be defined in order to determine and gather meaning from my action research project.

Real-world content: curriculum that allows a student to apply knowledge to the "greater world" within, as well as beyond, our rural community; specifically the real-world study of ecosystems and the development of a native organism by rearing trout from egg to fingerling stage and releasing in a local watershed Deep knowledge: "instruction addresses central ideas of a topic or discipline with enough thoroughness to explore connections and relationships and to produce relatively complex understanding" (MDE, 2007, p. 6)

\section{Research Question}

The following question, along with the subsequent search for its answer, will provide focus to my action research project.

1. What is the effect of implementing real-world content on students' deep knowledge? 


\section{Summary}

These research-based methods will make me a more effective teacher. I always tell my students that a goal of mine is to prepare them for the world outside of my classroom. My job is to teach them about science, but hopefully along the way, I can help give them some of the necessary tools to succeed in life. I want them to be excited about science and to be able to apply what they have learned to the "big picture". Living in the Upper Peninsula, we have a multitude of valuable natural and human resources at our fingertips. I want to help my students know more about and appreciate these resources, as well as be able to apply their knowledge to the greater world outside our rural community. Implementation of real-world content within an ecology unit will begin to allow me to reach this goal. 
This page deliberately blank 


\section{Chapter 2 - Literature Review}

\section{Introduction}

The desire to understand is an innate part of being human. We continue to evolve as we progress through life, constantly learning and adapting with each new experience. Connecting new ideas to pre-existing knowledge is vital to learning, and is an important skill for educators and formal education to hone (Bouillion \& Gomez, 2001). School functions as a ladder to the future, starting with the primary grades as the lowest rungs. Through various vehicles, life-long lessons must be learned as a student progresses through school. Using science content as my medium, I aim to make my students scientifically literate and prepare them for "real-world" situations.

\section{Definition of Scientific Literacy}

Scientific literacy provides a foundational goal for a quality science program, as it should be rigorous, as well as relevant. Learning with real-world contexts has been advocated since the writings of John Dewey (1902), and should be the goal of any effective educator. The National Science Teacher Association (NSTA) identified scientific literacy, the relationship between science and society, as its most important goal of science education in School Science Education for the 1970s. The scientifically literate person was one who "uses science concepts, process skills, and values in making everyday decisions as he interacts with other people and with his environment" and 
"understands the interrelationships between science, technology and other facets of society, including social and economic development" (NSTA, 1971, pp. 47-48). By 1982, the NSTA board of directors went on to state that the goal of science education was "to develop scientifically literate individuals who understand how science, technology, and society influence one another and who are able to use this knowledge in their everyday decision-making" (NSTA, 1982, p. 1). A quality science education was designed to give students the proper knowledge so that they could make decisions in the future about science-related social issues.

In addition, Paul DeHart Hurd defined a scientifically literate person as the holder of many traits including using "science knowledge where appropriate in making life and social decisions, forming judgments, resolving problems, and taking action" (1997, p. 413). Likewise, Angelo Collins stated that "understanding science and being able to use it in everyday life affairs are hallmarks of scientific literacy" (1997, p. 299). The relationship between real-world content and scientific literacy is an important part of a successful science classroom.

The ultimate goal of science education is scientific literacy for all. The National Science Education Standards state that "scientific literacy has become a necessity for everyone" (National Research Council, 1996, p. 1). Science teachers should encourage and hold high expectations of all students, try different methods of teaching, understand that students are unique in their learning process, make learning relevant to the lives of students, allow success and cooperative group work, and ensure that curriculum is inclusive of people with different backgrounds (Fraser-Abder, 2005). Effective teaching 
not only relates science content to different phenomena through these activities, but must also be introduced explicitly through multiple examples with ongoing feedback. Time and guidance to make sense of the content is also necessary (Kesidou \& Roseman, 2002).

Scientific literacy is dynamic rather than static. According to George DeBoer, director for Project 2061 of the American Association for the Advancement of Science (AAAS), "the goal of scientific literacy is achieved when the public learns about science and about the scientific enterprise in the many different ways it can be accomplished. At best, students have been introduced to science and the issues that science raises in society, and they like science and care enough about it to stay informed as adults" (2000, p. 597-598). It is the "ability to apply the values of science to one's life" (Kemp, 2000, p. 21). Scientific literacy must incorporate the "real uses of science in daily life" to ensure that it remains a relevant term in the world of science education (Feinstein, 2011, p. 168).

There are many different definitions of scientific literacy, but the general idea is that scientific literacy is a fundamental part of science, and should be a goal of all science education.

\section{Measuring Scientific Literacy}

Scientific literacy is an overarching goal of many science educators. In light of its different definitions, it can be difficult to measure. Many studies have looked at how it can be measured and how successful one can be at attaining it.

In the 1970s, a federally funded elementary science curriculum (Science Curriculum Improvement Study - SCIS), whose stated goal was to develop scientific 
literacy, was shown to have a positive effect on rural MI students. Students were evaluated in their ability to "perform mental operations, in the Piagetian sense, in order to give evidence of a satisfactory understanding of the concept" (Boyer \& Linn, 1976, p. 5). The students who had "direct science experiences were more successful in pencil-paper, problem solving tests requiring logical and scientific thinking than those who used textbooks" (Boyer \& Linn, 1976, p. 12). The "SCIS learning cycle of exploration, invention, and discovery of the concept appears to be effective for both learning specific concepts and scientific processes" (Boyer \& Linn, 1978, p. 217).

A study in the 1980s looked at what "combinations of student, teacher, curricular, and task factors characterize effective life science instruction, where effectiveness is defined as the acquisition of scientific literacy [study defined as: 1) explaining science content, 2) relating to science as a social historical process, 3) relating to science as a reasoning process, 4) relating science and society/technology, and 5) positive attitudes towards science]" (Mitman et. al., 1984, p. iii). Analysis of classroom materials indicated that a traditional curriculum with a focus on "recitation, seatwork, and laboratory exercises" were common. Pre- and post-tests indicated that "science knowledge, understanding, and reasoning increased," but that "student attitudes toward science generally declined over the year" (Mitman et. al., 1984, p. iv). The non-content components (2-5 in above definition) were largely disregarded in the curriculum. When interviewed, students felt that the main objective of the science class was to provide the "rote production of 'right answers' rather than analyzing and interpreting natural phenomenon" (Mitman et. al., 1984, p. iv). The study concluded that teachers should 
increase their use of the scientific literacy framework by including each of the representative parts of the definition. "Upgrading the cognitive level of tasks assigned to students" was also recommended (Mitman et. al., 1984, p. iv).

Champagne and Newell (1992) argue the need for alternative assessments in science, as they are a more authentic means of measuring literacy in science. The application of knowledge to real-world situations is an important part of scientific literacy; therefore "testing of student achievement in science must include assessment of a child's ability to think about scientific issues and apply information in real-world (outof-school) contexts" (Champagne \& Newell, 1992, p. 844). A "research and development" model was proposed where an assessment must be: 1) an accurate measurement of diverse components of scientific literacy, 2) authentic, 3) a motivation for performance in all students, 4) fair to all students of all populations, 4) an accurate interpretation of performance, 5) administered efficiently, and 6) including of strategies for administration and scoring (Champagne \& Newell, 1992).

In this light, a study done on sixth graders in Israel looked at the compulsory science curriculum, whose goal was to "educate all students towards 'scientific and technological literacy"' (Zuzovsky, 1997, p. 231). The curriculum was evaluated using alternative assessments that were authentic, fit to the cognitive hierarchy, and differentiated.

Assessing scientific literacy through interviews is another form of alternative assessment. Interviews are effective when "specific information is needed with respect to students' domain specific correct and incorrect conceptions and the language used to 
convey those conceptions in order to address these concerns" (Finley, 1986, p. 635). This information can be used to provide a "partial representation of the individual's cognitive structure" (Posner \& Gertzog, 1982, p. 195). An interesting finding was that interviews can provide evidence of a student's learning, even when a standard test may not. An example from the study was where a student did not learn a certain vocabulary term, but they understood the concept associated with the word (Finley, 1986). Researchers studying how seventh graders constructed scientific knowledge used interviews for similar reasons, as it "would allow students to give their own answers, and which would allow the [researchers] to probe the meanings of critical terms and ideas" (Carey et. al., 1986, p. 520). Interviews allowed researchers in a study done with eighth graders to better understand the reasoning behind the students' ideas, giving the researchers a "more holistic picture of the students' learning approaches" (Chin \& Brown, 2000, p. 131). These studies show that clinical interviews are an effective complement to other assessments.

As an example of measuring scientific literacy, a group at the University of Alberta looked at the ability of students to evaluate and assess the credibility of scientific investigations and their conclusions. These "reports are pervasive in classroom textbooks and the popular media" and are vital to an "educated populace that is scientifically and technologically competent” (Korpan et. al., 1994, p. 2). Participants in the study were given news briefs and were asked to "list the information they would need or questions they would want answered to help them evaluate the conclusion of the news brief" as well as to "justify how this information would help to evaluate the conclusion" (Korpan 
et. al., 1994, p. 3). Responses to these questionnaires were coded with the goal of making inferences about the students' knowledge of science (scientific literacy). The most frequent requests dealt with how the research was conducted (methods) and why the results occurred (theory). Requests dealing with social context (who conducted the research and where it was conducted) were infrequent (Korpan et. al., 1997). These findings seem to indicate a prevalence for the "process-orientated approach to science education," and a lack of understanding of the "social context in which research is conducted" (Korpan et. al., 1997, pp. 526-527).

International comparisons of literacy are becoming more common. The Program for International Student Assessment (PISA), a test that aims to "monitor the outcomes of the [the countries'] education systems in terms of student achievement, within a common international framework" is an example of a global focus on literacy. The test assesses Reading, Mathematics, and Science, with Science as the main focus in 2006 (Bybee, McCrae, \& Laurie, 2009, p. 865). The average U.S. fifteen-year-old's science literacy score was "statistically significantly below" the Organization for Economic Co-Operation and Development (OECD; consists of 30 democratic countries) average (U.S. score: 489; OECD average: 500). Of all the OECD countries, only $1.3 \%$ of students scored at the highest proficiency level, where they could "consistently identify, explain, and apply their knowledge of science, as well as their knowledge about science, in a variety of complex life situations" (Bybee, McCrae, \& Laurie, 2009, p. 876). 
As scientific literacy is stated to be a fundamental goal of science education, its measurement is also vital. Albeit difficult at times to quantify, a variety of assessments can and should be used to effectively evaluate scientific literacy.

\section{[Scientific Literacy in Michigan}

The State of Michigan, and its group of educators, has invested in scientific literacy through its Michigan Curriculum Framework. This curriculum aims to achieve scientific literacy for all. The Michigan Curriculum Framework states that schools "must prepare all students — regardless of their future aspirations — to be scientifically literate" (MI State Board of Education, 1996, p. 63). "Therefore, all graduates of our schools should be: (1) knowledgeable about the important concepts and theories of the three major branches of scientific study: earth, life, and physical sciences, (2) able to think scientifically and use scientific knowledge to make decisions about real-world problems, (3) able to construct new knowledge for themselves through research, reading, and discussion, (4) familiar with the natural world, and respectful of its unity, diversity, and fragility, (5) able to make informed judgments on statements and debates claiming to have a scientific basis, and (6) able to reflect in an informed way on the role of science in human affairs. To make this happen, education needs to: (1) emphasize understanding, not content coverage, (2) promote learning that is useful and relevant, (3) emphasize scientific literacy for ALL students, and (4) promote interdisciplinary learning" (MI State Board of Education, 1996, p. 63).

According to the Michigan Curriculum Framework, scientifically literate students should be able to (1) identify science principles, (2) use science principles, (3) apply 
scientific inquiry, and (4) reflect on scientific knowledge and be able to apply it in social implications (MI State Board of Education, 2006).

- Identifying science principles includes benchmarks such as "describe, measure, or classify observations."

- Using science principles benchmarks consist of "propose, analyze, and evaluate alternative explanations or predictions."

- Scientific inquiry benchmarks include "generate new questions that can be investigated in the laboratory or field."

- Reflection and social implication benchmarks include "identify and critique arguments based on scientific evidence" (MI State Board of Education, 2006, p. 4).

Each of these fundamental aspects in the Michigan Curriculum Framework provides the necessary foundation to help all students achieve the goal of scientific literacy.

A science curriculum that engages students in real-world content and is built from standards, including the Michigan Curriculum Framework, can be effective. Students in a study conducted in a group of Detroit public schools "showed improvement in their understanding not only at a recall, descriptive level but also showed an increased ability to apply information to new situations and draw relationships between concepts" (Rivet \& Krajcik, 2004, p. 686). Carlson (2008) found that the inquiry process, which is part of the Michigan Merit Curriculum standards, is an "effective option for increasing science literacy” (p. vi). Zolynsky (2007) investigated whether field studies, a real-world issue, were effective at improving motivation in her suburban Detroit students. She concluded 
that the students' content knowledge and motivation was improved with the implementation of relevant content in the science classroom.

Understanding where Michigan and its representative curriculum rank in the country is important. The National Assessment of Educational Progress (NAEP) is the "largest nationally representative and continuing assessment of what America's students know and can do in various subject areas" (U.S. Department of Education, 2010, p. 1). According to the average NAEP science scores, Michigan has the majority of students achieving at basic or above achievement levels in 2005 , with $69 \%$ for $4^{\text {th }}$ Grade and $66 \%$ for $8^{\text {th }}$ Grade. Michigan had a higher average science score (statistically significant) than the nation's average for $8^{\text {th }}$ Grade students (Nation's Report Card, 2005). The data from the 2009 NAEP test, which sheds some light on the effects of the Michigan Merit Curriculum, also found the majority of Michigan students achieving at or above basic achievement levels, with $72 \%$ for $4^{\text {th }}$ Grade and $66 \%$ for $8^{\text {th }}$ Grade. Michigan continued to have a higher average science score (statistically significant) than the nation's average for $8^{\text {th }}$ Grade students (Nation's Report Card, 2009).

The state of Michigan and its educators have made a commitment to achieving scientific literacy. This ongoing goal is important for the success of the students, as well as the future of the state.

\section{Relevancy and Scientific Literacy}

Ensuring that science content is relevant provides necessary limits to the long list of topics that can be included in a curriculum. Fewer science concepts that are presented 
in more depth, with an emphasis on real-world applications of science and interconnections between concepts, are more important than the "mile-long, inch-deep" curriculum (Rivet \& Krajcik, 2004). These nature of science (NOS) concepts include scientific inquiry (process, analysis, and communication), scientific reflections, and social implications; they are included in the Michigan Curriculum Framework and each of the Science Grade Level Content Expectations (MDE, 2007). Using methods that involve teaching with NOS in mind enhances both the understanding of science as well as interest in science (Hotchkiss \& Dickerson, 2008; McComas, Almazroa, \& Clough, 1998). Thinking about how each concept applies to problems that students may encounter in their adult lives is an important aspect to any curriculum, including science (Kolsto, 2001). Many textbooks and their standardized resources fall short when it comes to ensuring that students develop deep knowledge of a concept. Supplementing these resources, along with ensuring that material is relevant, is a necessary part of science teaching (Kesidou \& Roseman, 2002).

\section{Relevancy and Deep Knowledge}

Science should be taught in a way that promotes deep knowledge and application of scientific thought, rather than rote memorization of individualized facts. Scardamalia and Bereiter (2006) discuss the difference between knowledge "about" and knowledge "of" as the difference between simple and deep knowledge, respectively. Knowledge "about" dominates traditional educational practice and is the backbone of textbooks and many curriculum guides. Knowledge "of" is found more in relevant problem-based 
activities. The knowledge "of" consists of a much richer understanding than simple facts that can be regurgitated on a standardized test. It is called upon in cases where the knowledge must be used in the "real-world." The authors discussed an example relating to sky-diving. Knowledge "about" sky-diving would include declarative knowledge that a person could regurgitate in a discussion or test situation. Knowledge "of" sky-diving would imply that the person could actually sky-dive and include both procedural and declarative knowledge (Scardamalia and Bereiter, 2006).

The higher-order approach of knowledge "of" works in a variety of classrooms, and has been shown in a study with a group of middle school students having shown significant achievement in scientific knowledge when taught with lessons that involved relevant hands-on learning (knowledge "of'), versus learning passively through the use of textbooks (knowledge "about") (McCarthy, 2005).

\section{Benefits of Real-World Content in the Classroom}

Whether it is science or any other subject, students must make connections to their community, as well as the greater world around them. A disconnect can occur when students do not see how science connects to their own lives, as well as when schools do not see how students' life experiences have value in understanding and practicing science (Bouillion \& Gomez, 2001). These connections between students, their schools, and their communities can be made stronger by encouraging the application of real-world problems. These real-world problems feature "no clear answer and are interdisciplinary in nature, are relevant to and of interest to curriculum and students' lives, and are highly 
visible and accessible to students" (Bouillion \& Gomez, 2001). This is vital to the fundamental function of society where knowledge, especially that which is beneficial to the community, is advanced (Scardamalia \& Bereiter, 2006).

An effective classroom that includes real-world content must be complete and supportive. Effective science instruction should include activities that are used by scientists and are relevant to students' lives. Students should be able to collect and analyze real-world data. Students and teachers must collaborate in the classroom; everyone is important for the success of a successful classroom. The classroom must connect students with the community, as this is an important aspect of implementing realworld content. A connected science classroom should include activities that would be representative of a professional science laboratory. Students should be involved in the design, implementation, and analysis of experimental data. Finally, students should be actively involved in the classroom. With the teacher's guidance and support, students should begin to take ownership and begin to be advocates for their own education (Crawford, 2000). This student involvement helps promote higher-order thinking (Lung, 1999).

The use of real-world content in the classroom has benefits for all students, including those with special needs (Gersten \& Baker, 1998) and diverse backgrounds (Bouillion \& Gomez, 2001). All students should be included in activities that involve real-world applications of science concepts, as they have the potential for increasing deep knowledge of concepts taught in school (Gersten \& Baker, 1998) 
Rearing trout in my classroom will serve as the real-world content in my study. I have based my project on similar endeavors, including Salmon in the Classroom (done in MI and AK) and Trout in the Classroom (various states). Raising salmon promoted the understanding of NOS in fourth graders (Akerson \& Abd-El-Khalick, 2003), as well as a group of schools in Alaska (Timmons, Hansen, \& Raymond, 2009).

\section{Summary}

Science should be taught as directly relevant to our lives and as the study of our world and how it works. Through the understanding of scientific concepts, students will have a better idea of who they are and where they fit into the greater world around them. 


\section{Chapter 3 - Design}

\section{Introduction}

The real-world content of rearing trout was implemented into my $6^{\text {th }}$ Grade science curriculum. The relevancy of this hands-on project is excellent, with students having an opportunity to practice "real science" and play a role in the development of a native resource. The school, which is surrounded by blue-ribbon trout streams and quality trout lakes, provides a perfect setting for students to become engaged and better understand the environment around them.

The unit curriculum is designed so students can begin to develop a life-long sense of ecological stewardship and appreciation through this experience. The effects on deep knowledge of life science content, specifically ecosystems (L.EC.M.1, L.EC.M.2, L.EC.M.3, and L.EC.M.4 from MDE - Grade Level Content Expectations; Table 1) will be determined through various sources, including pre- and post-tests, formative and summative assessments, and interviews. 
Table 1. Sixth Grade Level Content Expectations and Michigan Curriculum Framework used for the Ecology Unit
Framework
Michigan Grade Level Content Expectations
L.OL.06.51
Classify organisms (producers, consumers, and decomposers) based on
their source of energy for growth and development.
L.OL.06.52
Distinguish between the ways in which consumers and decomposers
obtain energy.
L.EC.06.21
Describe common patterns of relationships between and among
populations (competition, parasitism, symbiosis, predator/prey).
L.EC.06.22 Explain how two populations of organisms can be mutually beneficial and how that can lead to interdependency.
L.EC.06.23 Predict how changes in one population might affect other populations based upon their relationships in the food web.
L.EC.06.31 Identify the living (biotic) and nonliving (abiotic) components of an
ecosystem.
L.EC.06.32
Identify the factors in an ecosystem that influence changes in population size.
Describe how human beings are part of the ecosystem of the Earth and
L.EC.06.41 that human activity can purposefully, or accidentally, alter the balance in ecosystems.
Predict possible consequences of overpopulation of organisms, including
L.EC.06.42 humans, (for example: species extinction, resource depletion, climate change, pollution).

\section{Setting}

The research was conducted at Forest Park Schools in Crystal Falls, Michigan.

Crystal Falls is a rural community of 2500 people located in eastern Iron County in the Upper Peninsula of Michigan. The school plays a large role in the area, acting both as a major employer and the "community center." 
The study site will be a science laboratory, which is my $6^{\text {th }}$ Grade science classroom. The K-12 school has approximately 500 students total, averaging about 42 to a graduating class. The socioeconomic background of the school population is mainly white, lower-middle class. The demographics of the Forest Park $6^{\text {th }}$ Grade are similar to the overall school student body (Table 2).

\section{Table 2. Forest Park Sixth Grade Student Demographics}

\begin{tabular}{lcc}
\hline Demographic & Whole School $\%{ }^{3}$ & $6^{\text {th }}$ Grade $\%$ \\
\hline Race: Non-white & 3 & 2 \\
Economically Disadvantaged Students ${ }^{1}$ & 49 & 55 \\
Special Education Students & 21 & 16 \\
At Risk Students & \\
& 42 & 48 \\
\hline $\begin{array}{l}\text { Note. } \\
{ }^{1} \text { Identified through the free and reduced lunch program; }{ }^{2} \text { Based on personal or family history of failure in school, divorce, }\end{array}$
\end{tabular}

\section{Informed Consent}

All participants and their guardians signed an informed consent form that discussed the ethical and legal issues within the study (Appendix N). The form included a summary of the study as well as how each student would be involved in the project. Forms that were signed and returned by students and parents provided consent for the student's participation in the study. Students who did not consent, or whose parents did not consent, were excluded from data collection for the research study; they would still participate in the unit so they would not be excluded from learning the material (all 
participants consented). The school administration was made aware and was supportive of this curriculum change and action research, along with its potential benefits to our school.

\section{Participants}

Two sections of sixth grade science were referred to as Section 6-2 ( $2^{\text {nd }}$ hour) and 6-7 $\left(7^{\text {th }}\right.$ hour). Ages ranging from 11 to 13 years old were used. Since one class would be the experimental and the other the control, the demographic and academic similarity between the classes was analyzed. Prior knowledge of the groups was compared using reading and math test scores from the Standardized Test for the Assessment of Reading (STAR), math, reading, social studies, and science test scores from the Michigan Educational Assessment Program (MEAP), and semester grades from my class. Class size, gender, average semester grades and Science MEAP composite scores were highlighted as the main focus of comparison (Table 3).

The classes were similar, allowing analysis of the effects of the use of real-world content by a comparison of the two classes. Class sizes and gender ratios were comparable. The coefficient of variance between the two groups for their semester grades and science MEAP composite scores was small. The difference in semester grades and science MEAP composite scores between the classes was not statistically significant ( $\mathrm{t}$ Test: 0.34 and 0.28 , respectively). 
Table 3. Comparison of the Second and Seventh Hour Classes Used in the Study

\begin{tabular}{|c|c|c|c|c|c|c|c|}
\hline \multirow[b]{2}{*}{ Class } & \multirow[b]{2}{*}{$\mathrm{N}$} & \multicolumn{2}{|c|}{ Sex } & \multicolumn{2}{|c|}{ Semester Grade } & \multicolumn{2}{|c|}{$\begin{array}{l}\text { Science MEAP } \\
\text { Composite }\end{array}$} \\
\hline & & Male & Female & Mean & $\begin{array}{l}\text { Standard } \\
\text { Deviation }\end{array}$ & Mean & $\begin{array}{l}\text { Standard } \\
\text { Deviation }\end{array}$ \\
\hline Section 6-2 & 21 & 11 & 10 & 83.0 & 8.4 & 537.25 & 27.74 \\
\hline Section 6-7 & 23 & 11 & 12 & 80.6 & 8.2 & 527.52 & 28.81 \\
\hline Mean & & & & 81.8 & & 532.39 & \\
\hline Std Dev & & & & 1.2 & & 4.87 & \\
\hline $\begin{array}{c}\text { Coefficient of } \\
\text { Variance }\end{array}$ & & & & $1.4 \%$ & & $0.9 \%$ & \\
\hline
\end{tabular}

Refinement of Comparison Group Membership. In order to make the two groups as similar to each other as possible, a subset of paired individuals from the respective classes was created by comparing students using three criteria. Gender, at-risk status, and MEAP Science Composite scores were used. It was decided ahead of time to pair a student from the control class with a student from the experimental class with the same gender, at-risk status, and MEAP Science Composite score within $1 / 2$ standard deviation (e.g. at-risk male from control group with MEAP Science composite score of 521 paired with at-risk male from experimental group with MEAP Science composite score of 524). 
Ten pairs were established using the criteria. Two teachers and a professor of education independently used the process and came up with the same individuals in each group, thus establishing an inter-rater reliability of $100 \%$.

The smaller group of matched experimental/control subjects greatly increased the similarity between the two experimental and control groups. Mean semester grades and cumulative science MEAP scores, along with their respective standard deviations, were more alike in the matched experimental/control subjects (Table 4) than in the two classes as a whole (Table 3). Class sizes and gender ratios were the same. The coefficient of variance between the matched experimental/control subjects for their semester grades and science MEAP composite scores was smaller than the two whole classes. The difference in semester grades and science MEAP composite scores between the matched experimental/control subjects was not statistically significant (t-Test: 0.52 and 0.89 , respectively). Therefore, all statistical analysis of testing results was done between the matched experimental/control subjects. 
Table 4. Comparison of the Second and Seventh Period Classes Using only the Matched Experimental/Control Subjects

\begin{tabular}{|c|c|c|c|c|c|c|c|}
\hline \multirow[b]{2}{*}{ Class } & \multirow[b]{2}{*}{$\mathrm{N}$} & \multicolumn{2}{|c|}{ Sex } & \multicolumn{2}{|c|}{ Semester Grade } & \multicolumn{2}{|c|}{$\begin{array}{l}\text { Science MEAP } \\
\text { Composite }\end{array}$} \\
\hline & & Male & Female & Mean & $\begin{array}{l}\text { Standard } \\
\text { Deviation }\end{array}$ & Mean & $\begin{array}{l}\text { Standard } \\
\text { Deviation }\end{array}$ \\
\hline $\begin{array}{c}\text { Section 6-2 } \\
\text { Subset }\end{array}$ & 10 & 6 & 4 & 82.7 & 7.9 & 531.80 & 19.36 \\
\hline $\begin{array}{c}\text { Section 6-7 } \\
\text { Subset }\end{array}$ & 10 & 6 & 4 & 84.9 & 6.7 & 533.10 & 20.78 \\
\hline Mean & & & & 83.8 & & 532.39 & \\
\hline Std Dev & & & & 1.1 & & 0.65 & \\
\hline $\begin{array}{c}\text { Coefficient of } \\
\text { Variance }\end{array}$ & & & & $1.3 \%$ & & $0.1 \%$ & \\
\hline
\end{tabular}

\section{Design}

The two sections were randomly assigned as the control and experimental group (coin flip). Section 6-2 was the control class and was taught the ecology standards using the lessons that were used the previous year. These lessons were based on a "traditional" unit of a reading assignment, lecture, lab, and assessment. A reading assignment began the unit in order to build up background information, so that the subsequent lecture would be more effective. A lab followed in order to reinforce the reading assignment and lecture. Finally, an assessment was used to evaluate the students' gain in knowledge.

The experimental group was Section 6-7. This group was taught using the realworld content of rearing trout in the classroom as a vehicle to learn ecology (Table 5). 


\section{Table 5. Comparison of the Curriculum Between the Control and Experimental Class}

\begin{tabular}{ccccc}
\hline Class & $\begin{array}{c}\text { Real-world } \\
\text { Content of } \\
\text { Rearing Trout } \\
\text { Unit }\end{array}$ & $\begin{array}{c}\text { Traditional } \\
\text { Unit }\end{array}$ & $\begin{array}{c}\text { Pre- and Post- } \\
\text { Test }\end{array}$ & $\begin{array}{c}\text { Clinical } \\
\text { Interview }\end{array}$ \\
\hline $\begin{array}{c}\text { Section 6-2 } \\
\text { (Control) }\end{array}$ & & $\mathrm{X}$ & $\mathrm{X}$ & $\mathrm{X}$ \\
$\begin{array}{c}\text { Section 6-7 } \\
\text { (Experimental) }\end{array}$ & $\mathrm{X}$ & & $\mathrm{X}$ & $\mathrm{X}$ \\
\hline
\end{tabular}

\section{Curriculum}

The unit involving ecology content took fourteen weeks to complete. It included

five subunits [1) producers, consumers, and decomposers, 2) interactions of organisms, 3) relationships of organisms, 4) biotic and abiotic factors, and 5) environmental impacts of organisms]. Each subunit took about two weeks to complete. The subunits were aligned with the Michigan Curriculum Framework.

Lessons in the experimental group incorporated the real-world content of rearing trout throughout the unit. Students were directly involved in the life cycle of the trout, working with them from eyed egg stage to fingerling (3 inches in length) stage. Eggs were obtained in the fall and were reared in an aquarium with a filter and chiller unit to help keep the water at the correct temperature and chemistry level. Students took turns volunteering for jobs involving the trout on a weekly basis, so that everyone could be involved. These jobs included feeding the fish (daily), checking the water temperature (daily), testing the water chemistry including ammonia, nitrite, nitrate, and $\mathrm{pH}$ levels 
(twice a week), checking the equipment (daily), cleaning the tank and replacing the tank water (twice a week), and checking for and removing any dead trout (daily). Work occurred before and after school, as well as during class time. Representatives would record the day's data on the board for the class to record in their daily journals. Discussions involving the ecology of the trout occurred throughout the unit. These discussions included the trout's role as a consumer, factors that affect their population, what community and ecosystem they lived in, what symbiotic relationships they were part of, the biotic and abiotic factors that affect them, and how humans have impacted them, both positively and negatively. Whenever a topic or question would come up, we would try and relate it to the trout. This helped provide real-world context to the learning process. The experimental students received the same curriculum as the control students, plus each experimental student received an additional 15-20 minutes of direct instruction per week involving trout ecology.

Although the trout were part of the science classroom environment, the control group was not directly involved with them in an educational manner. The control students did not participate in the jobs involving the trout. While the experimental group used the trout for real-world content, the control group would use general examples.

The ecology unit began with a review of the definition and applications of life science, as this unit was the "life science" unit for the sixth grade. The "Big Ideas," objectives, and vocabulary for the unit, which are based on the MI Grade Level Content Expectations (Appendix B), were reviewed in the same way for both the control and experimental class. 
The first subunit was Producers, Consumers, and Decomposers, and began with a discussion involving PowerPoint ${ }^{\circledR}$ notes that included the representative MI Grade Level Content Expectations (GLCEs, L.OL.6.51 and L.OL.6.52). Both classes then went through an energy lab where the student had to record all activities and everything they consumed for a 24 hour period. This lab applied the concept of the acquisition and use of energy and its transfer by directly correlating the amount of energy a student brings in and uses. Finally, the students took a quiz that assessed the MI GLCEs dealing with Producers, Consumers and Decomposers. Examples of PowerPoint ${ }^{\circledR}$ notes and the quiz for this unit can be found in Appendix C.

The second subunit, Interactions of Organisms, started with two reading assignments titled "The Concept of the Ecosystem" and "Freshwater Biomes." Students in both classes were asked to read and summarize the articles in their science journals. PowerPoint ${ }^{\circledR}$ notes that included the representative MI GLCEs (L.OL.6.11) were then used in a discussion format. Both classes completed an Upper Peninsula of Michigan Research Summary where they researched an Upper Peninsula of Michigan population of their choice, as well as it respective community and ecosystem. Finally, students in both classes completed an Ecosystem Value project where they created a brochure that sold the "value" of a respective Michigan ecosystem. Examples of PowerPoint ${ }^{\circledR}$ notes, student's research summaries, and Ecosystem Value projects for this unit can be found in Appendix D.

The third subunit, Relationships of Organisms, began with a United States Forest Service article involving wolf and moose research on Isle Royale. Students in both 
classes were given questions to answer based on the article. A discussion involving PowerPoint ${ }^{\circledR}$ notes that included the representative MI GLCEs (L.OL.6.21, L.OL.6.22, and L.OL.6.23) followed. Both classes then completed a Symbiosis Comparison Matrix where they had to research examples of Competition, Parasitism, Symbiosis, and Predation, and then share in a "pair-share" format with small groups. All students also completed a predator/prey simulation where they had to graph the predator and prey populations over time and then analyze the data. Finally, all students took a quiz that assessed the MI GLCEs dealing with Relationships of Organisms. Examples of the PowerPoint ${ }^{\circledR}$ notes, student's symbiosis matrix, student's predator/prey simulation, and the quiz for this unit can be found in Appendix E.

The Biotic and Abiotic Factors subunit began with a discussion involving PowerPoint ${ }^{\circledR}$ notes that included the representative MI GLCEs (L.OL.6.31 and L.OL.6.32). Both classes then completed a Population Density Lab where students were asked to figure out the density of the "class population." Biotic and abiotic factors were applied by having the students model and analyze answers to scenarios where the population in the room doubled and/or there was habitat loss. The experimental students specifically discussed the factors affecting the trout including biotic (other trout) and abiotic (temperature, amount of light, $\mathrm{pH}$, and chemical levels including Ammonia, Nitrate, and Nitrite). The control group spent the same amount of time discussing general biotic and abiotic factors. Examples of the PowerPoint ${ }^{\circledR}$ notes can be found in Appendix F. 
The Environmental Impacts of Organisms was the final subunit. It began with a discussion involving PowerPoint ${ }^{\circledR}$ notes and online resources (NOVA "World in the Balance"; http://www.pbs.org/wgbh/nova/worldbalance/numbers.html) that included the representative MI GLCEs (L.OL.6.41 and L.OL.6.42). Both classes then completed an activity where students had to determine their personal "ecological footprint" using http://www.myfootprint.org. After completing the online quiz and recording the size of their footprint, students were asked to formulate and analyze relevant ways that they could reduce their impact on the Earth. These suggestions were written on an image of a human footprint and posted outside in the hall for everyone to see. All students then completed a cross-curricular project with the middle school Language Arts department where they had to write a persuasive essay answering: "How can I reduce my ecological footprint, and why is it vital to ecological sustainability?" Examples of the PowerPoint ${ }^{\circledR}$ notes, student's suggestions for reducing their impact, and a student's research paper can be found in Appendix G.

Both classes participated in the release of the trout fingerlings in the spring. The trout were stocked into a local lake that was designed for youth fishing and contained a handicapped-accessible pier. Releasing the trout required a Public Waters Stocking Permit from the Michigan Department of Natural Resources (Appendix H). The public lake is within biking distance of town and the school. 


\section{Assessment}

A variety of instruments were used to collect data before, during, and after the action research project (Table 6).

Table 6. Sources of Data used in Research

\begin{tabular}{|c|c|c|c|c|}
\hline Class & $\mathrm{N}$ & Pre-Tests & Treatment & Post-Tests \\
\hline $\begin{array}{c}\text { Section 6-2 } \\
\text { (Control Subset) }\end{array}$ & 10 & $\begin{array}{c}\text { Ecology } \\
\text { Content Pre- } \\
\text { Test }\end{array}$ & $\begin{array}{l}\text { Traditional } \\
\text { Pedagogy }\end{array}$ & $\begin{array}{c}\text { Ecology Content } \\
\text { Post-Test; Group } \\
\text { Test; Clinical } \\
\text { Interview of } \\
\text { Sample }(\mathrm{N}=3)\end{array}$ \\
\hline $\begin{array}{c}\text { Section 6-7 } \\
\text { (Experimental } \\
\text { Subset) }\end{array}$ & 10 & $\begin{array}{c}\text { Ecology } \\
\text { Content Pre- } \\
\text { Test }\end{array}$ & $\begin{array}{c}\text { Real-world } \\
\text { Content } \\
\text { Based } \\
\text { Pedagogy }\end{array}$ & $\begin{array}{c}\text { Ecology Content } \\
\text { Post-Test; Group } \\
\text { Test; Clinical } \\
\text { interview of } \\
\text { Sample }(\mathrm{N}=4)\end{array}$ \\
\hline
\end{tabular}

Prior to beginning the ecology unit, I gave each of my sixth grade students the ecology pre-test, which involved multiple-choice and objective questions, to complete (Appendix A). I allowed the students one class period (50 minutes) to complete the test.

Fourteen weeks later, the ecology unit concluded with several forms of summative assessment. All students were put into small groups and presented with a poster representing a Michigan ecosystem. The group had to identify and describe the ecological characteristics of their respective ecosystem including: 1) Producers, Consumers, Decomposers: identify and describe example food chain from poster, 2) Interactions of Organisms: identify and describe example population and interdependent populations (community) from poster and identify and describe type of ecosystem shown 
in poster, 3) Relationships among Organisms: identify and describe an example of relationship in poster, 4) Biotic and abiotic factors: identify and describe five abiotic factors from poster, and 5) Environmental Impacts of Organisms: assuming an invasive species is introduced by humans to your example ecosystem, predict and describe possible impacts on overall ecosystem in poster. Group answers were evaluated using a self-developed rubric, and were figured into the students' class grades (Appendix I). The group answers were not used for the project's data analysis.

All students also completed the ecology post-test, which was the same as the pretest (Appendix A). The test was developed to measure ecology content mastery and was part of the students' class grade, as well as part of the data analysis. Forty-six multiple choice items from a biology textbook test bank (Postlethwait \& Hopson, 2006) or written by myself were aligned with the Michigan Curriculum Framework and Bloom's Taxonomy in the Cognitive Domain (Table 7). Three constructed response items that pushed the content deeper than the multiple choice items were written and aligned with the Michigan Curriculum Framework and Bloom's Cognitive Level (Table 7), and were graded with a self-developed rubric (Appendix J).

Clinical interviews (Appendix L) were also used in a random (names drawn) sample (7 students from the matched experimental/control subjects) of the overall population. Using students from the matched experimental/control subjects helped insure that they would be representative of the overall class in general. These students were individually interviewed at the conclusion of the unit. These interviews are an additional means of measuring students' knowledge, as they have been shown to "provide specific 
insight into how students' knowledge changes as a result of instruction" (Finley, 1986, p. 636) and show the "relevant conceptions he or she holds and the perceived relationships among those conceptions" (Posner \& Gertzog, 1982, p. 195). The interviews helped me to further answer my research question that looked at the effects of implementing realworld content on students' deep knowledge. A researcher can gather and analyze data from a multiple choice and constructed response assessment, but a clinical interview helps to really "see" into a subject's thought process and why they answered a certain way. This analysis allowed me to better measure the gain in students' deep knowledge. Interviews were conducted at the conclusion of the ecology unit, one week after the post-test was completed. The interviews centered on two items from the pre- and post-test (items \#46 and \#11), and one application question relating to an ecology concept. Interviews averaged about 10 minutes per student. Students were interviewed individually and were voice-recorded for analysis purposes. The student and teacher sat opposite each other at a table in the science classroom, with discussion cues written in large print on cards in front of the student. 


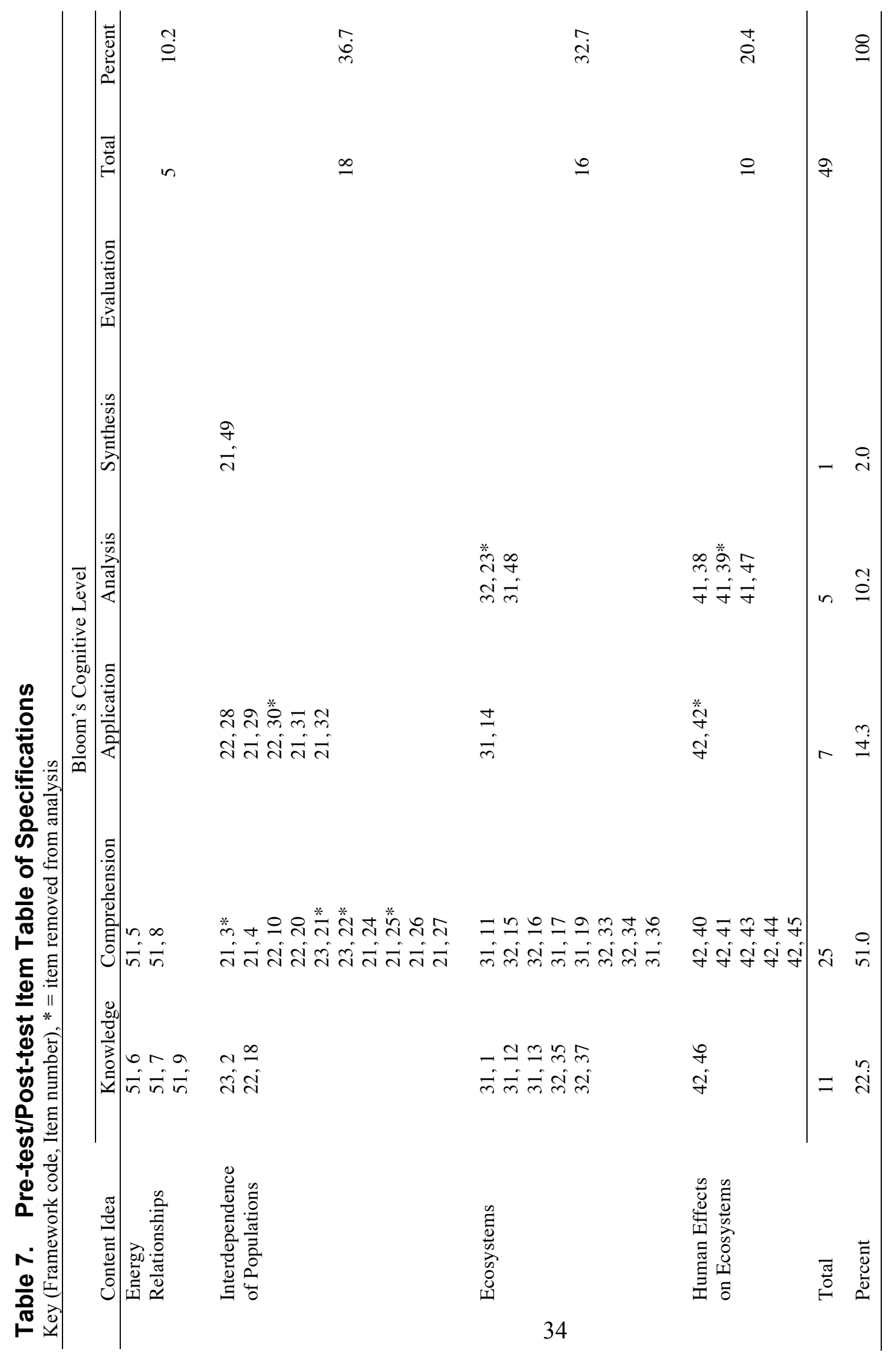




\section{Chapter 4 - Data}

Data analysis was completed to measure the effects of implementing real-world content in my science classroom, and its improvement of students' deep knowledge of ecosystem content. Item analyses were done on the multiple-choice portion of the posttest, which resulted in the removal of several test items from the final analysis version. The constructed response portion was graded with a rubric, with analysis additionally completed through the use of clinical interviews in a sample of the population.

Comparisons of the experimental and control group was done through the matched experimental/control subjects. Analysis of data included quantitative gains from the pre-tests to the post-tests and qualitative data from the clinical interviews.

\section{Scoring and Item Analysis of the Multiple Choice Part of Post-test}

The multiple-choice part of the post-test was completed by the students using bubble forms. The forms were scanned for scoring and an item analysis was performed (Tables 8 and 9) using both item difficulty and item discrimination (Cunningham, 1986; Worthen et. al. 1999).

Table 8 is a compilation of data from each class that looks at item difficulty for each multiple-choice item on the post-test. The item difficulty $(\mathrm{P})$ was determined by:

$$
P=\left(\frac{N_{\text {correct }}}{N_{\text {attempts }}}\right) \times 100 \%
$$


Item difficulties for the multiple-choice parts of the post-test had a range of $75 \%$, with students answering 93\% correct on the least difficult item (Item 30) to answering $18 \%$ correct on the most difficult item (Item 23).

Table 8. Item Difficulty (Multiple-choice Post-test)

\begin{tabular}{|c|c|c|c|}
\hline Question \# & $\mathrm{N}_{\text {attempts.total }}$ & $\mathrm{N}_{\text {correct.total }}$ & Item difficulty $(\mathrm{P})$ \\
\hline 1 & 44 & 34 & 0.77 \\
\hline 2 & 44 & 30 & 0.68 \\
\hline 3 & 44 & 20 & 0.45 \\
\hline 4 & 44 & 36 & 0.82 \\
\hline 5 & 44 & 40 & 0.91 \\
\hline 6 & 44 & 32 & 0.73 \\
\hline 7 & 44 & 15 & 0.34 \\
\hline 8 & 44 & 36 & 0.82 \\
\hline 9 & 44 & 35 & 0.80 \\
\hline 10 & 44 & 22 & 0.50 \\
\hline 11 & 44 & 37 & 0.84 \\
\hline 12 & 44 & 32 & 0.73 \\
\hline 13 & 44 & 23 & 0.52 \\
\hline 14 & 44 & 17 & 0.39 \\
\hline 15 & 44 & 35 & 0.80 \\
\hline 16 & 44 & 18 & 0.41 \\
\hline 17 & 44 & 37 & 0.84 \\
\hline 18 & 44 & 27 & 0.61 \\
\hline 19 & 44 & 25 & 0.57 \\
\hline 20 & 44 & 16 & 0.36 \\
\hline 21 & 44 & 36 & 0.82 \\
\hline 22 & 44 & 9 & 0.20 \\
\hline 23 & 44 & 8 & 0.18 \\
\hline 24 & 44 & 37 & 0.84 \\
\hline 25 & 44 & 34 & 0.77 \\
\hline 26 & 44 & 19 & 0.43 \\
\hline 27 & 44 & 23 & 0.52 \\
\hline 28 & 44 & 36 & 0.82 \\
\hline 29 & 44 & 34 & 0.77 \\
\hline
\end{tabular}


Table 8. Item Difficulty (Multiple-choice Post-test) (continued)

\begin{tabular}{cccc}
\hline Question \# & $\mathrm{N}_{\text {attempts.total }}$ & $\mathrm{N}_{\text {correct.total }}$ & Item difficulty (P) \\
\hline 30 & 44 & 41 & 0.93 \\
31 & 44 & 24 & 0.55 \\
32 & 44 & 20 & 0.45 \\
33 & 44 & 31 & 0.70 \\
34 & 44 & 35 & 0.80 \\
35 & 44 & 24 & 0.55 \\
36 & 44 & 39 & 0.89 \\
37 & 44 & 15 & 0.34 \\
38 & 44 & 24 & 0.55 \\
39 & 44 & 34 & 0.77 \\
40 & 44 & 31 & 0.70 \\
41 & 44 & 30 & 0.68 \\
42 & 44 & 32 & 0.73 \\
43 & 44 & 29 & 0.66 \\
44 & 44 & 32 & 0.73 \\
45 & 44 & 28 & 0.64 \\
46 & 44 & 20 & 0.45 \\
\hline Average & & & 0.64 \\
Standard Deviation & & & 0.19 \\
\hline
\end{tabular}

Items 22 and 23 had the highest difficulty rating for both class sections (Section 6-2: 28.57 and 23.81; Section 6-7: 13.04 and 13.04, respectively). These items dealt with topics that we were not able to spend much time on during the unit. A decision was made to drop the items from the subsequent analysis.

Item discrimination for each multiple-choice item on the post-test was performed (Table 9). The item discrimination (D) was determined by:

$$
D=\frac{N_{\text {correct.high }}-N_{\text {correct.low }}}{N_{\text {group }}}
$$

Item discrimination is a good measure of the effectiveness of an item. Students are split into groups based on their level of understanding or achievement. The $\mathrm{N}_{\text {group }}$ for 
this research was based on the upper and lower $37.5 \%$ of students' semester grades established prior to the unit, with 15 students falling in each the upper and lower groups. Item discrimination is the difference between percentage correct for the two groups, and can range from +1.0 to -1.0 . Item discriminations for the multiple-choice test ranged from 0.47 (Items 14 and 33) to -0.13 (Items 21 and 39). Negative discriminations result when more students in the lower group answer the item correctly than students in the upper group, which can indicate unreliability in an item.

Table 9. Item Discrimination (Multiple-choice Post-test)

\begin{tabular}{ccccc}
\hline Item $\#$ & $\mathrm{~N}_{\text {attempts.total }}$ & $\mathrm{N}_{\text {correct.total }}$ & $\mathrm{N}_{\text {group }}$ & $\begin{array}{c}\text { Item } \\
\text { discrimination } \\
(\mathrm{D})\end{array}$ \\
\hline 1 & 44 & 20 & 15 & 0.13 \\
2 & 44 & 23 & 15 & 0.13 \\
3 & 44 & 30 & 15 & -0.07 \\
4 & 44 & 37 & 15 & 0.27 \\
5 & 44 & 27 & 15 & 0.20 \\
6 & 44 & 15 & 15 & 0.00 \\
7 & 44 & 15 & 15 & 0.33 \\
8 & 44 & 24 & 15 & 0.00 \\
9 & 44 & 25 & 15 & 0.20 \\
10 & 44 & 20 & 15 & 0.40 \\
11 & 44 & 30 & 15 & 0.07 \\
12 & 44 & 36 & 15 & 0.13 \\
13 & 44 & 36 & 15 & 0.33 \\
14 & 44 & 34 & 15 & 0.47 \\
15 & 44 & 35 & 15 & 0.33 \\
16 & 44 & 15 & 15 & 0.20 \\
17 & 44 & 35 & 15 & 0.07 \\
18 & 44 & 36 & 15 & 0.40 \\
19 & 44 & 32 & 15 & 0.27 \\
20 & 44 & 34 & & 0.00 \\
\hline & & & $(\mathbf{c o n t i n u e d})$
\end{tabular}


Table 9. Item Discrimination (Multiple-choice Post-test) (continued)

\begin{tabular}{ccccc}
\hline Item \# & $\mathrm{N}_{\text {attempts.toal }}$ & $\mathrm{N}_{\text {correct.total }}$ & $\mathrm{N}_{\text {group }}$ & $\begin{array}{c}\text { Item } \\
\text { discrimination } \\
\text { (D) }\end{array}$ \\
\hline 21 & 44 & 28 & 15 & -0.13 \\
22 & 44 & 24 & 15 & 0.07 \\
23 & 44 & 39 & 15 & 0.07 \\
24 & 44 & 35 & 15 & 0.13 \\
25 & 44 & 32 & 15 & -0.07 \\
26 & 44 & 36 & 15 & 0.20 \\
27 & 44 & 41 & 15 & 0.13 \\
28 & 44 & 31 & 15 & 0.00 \\
29 & 44 & 9 & 15 & 0.20 \\
30 & 44 & 29 & 15 & -0.07 \\
31 & 44 & 23 & 15 & 0.27 \\
32 & 44 & 25 & 15 & 0.13 \\
33 & 44 & 22 & 15 & 0.47 \\
34 & 44 & 8 & 15 & 0.20 \\
35 & 44 & 40 & 15 & 0.40 \\
36 & 44 & 16 & 15 & 0.27 \\
37 & 44 & 37 & 15 & 0.20 \\
38 & 44 & 34 & 15 & 0.20 \\
39 & 44 & 20 & 15 & -0.13 \\
40 & 44 & 22 & 15 & 0.33 \\
41 & 44 & 34 & 15 & 0.27 \\
42 & 44 & 32 & 15 & -0.07 \\
43 & 44 & 18 & 15 & 0.27 \\
44 & 44 & 37 & 15 & 0.27 \\
45 & 44 & 21 & 15 & 0.13 \\
46 & 44 & 32 & 15 & 0.40 \\
\hline Average & & & & 0.17 \\
Standard Deviation & & & & 0.16 \\
\hline & & & & \\
& 44 & 15 & 15 \\
\hline
\end{tabular}

Items 3, 25, 30, 42, 21, and 39 each had negative discriminations. A decision was made to drop the items from the subsequent analysis. 
The post-test used for analysis had a final total of 38 items, since 2 items (22 and 23) were removed for item difficulty and 6 items $(3,25,30,42,21$, and 39) were removed for negative discrimination. The resulting test still represented the context of the ecology, covering all of the appropriate $6^{\text {th }}$ Grade Level Content Expectations (Table 1) and aligning well with Bloom's Cognitive Levels (Table 7 where removed items are marked with *).

\section{Scoring and Item Analysis of the Constructed Response Part of Post-test}

The constructed response section was scored by hand using a self-developed rubric (Appendix J). Results of these tests were compared between classes (control and experimental) and matched experimental/control subjects. Examples of post-test constructed responses from two students can be found in Appendix K.

Additional analysis of the constructed response section was done through clinical interviews using a sample of the students from both the experimental and control classes. Students were questioned on different ecology concepts, including relevant vocabulary and applications. Students' answers were recorded and written down, and were analyzed to provide an additional means of measuring student knowledge.

\section{Pre-Test and Post-Test Comparison}

The ecology unit improved student's understanding of the MI Grade Level Content Expectations. Gains in knowledge occurred both in the control and experimental 
classes, with the majority of students showing improvement from the pre-test to the posttest.

Multiple-Choice Test. Students in both the control and experimental classes gained knowledge from the pre-test to the post-test for the multiple-choice section. Data is from the multiple-choice test where items were removed after item analysis (Table 10, Figures 1 and 2).

Table 10. Students Pre-test and Post-test Multiple-choice Score

\begin{tabular}{|c|c|c|c|c|c|}
\hline \multicolumn{3}{|c|}{ Control } & \multicolumn{3}{|c|}{ Experimental } \\
\hline & $\begin{array}{c}\text { Pre-test } \\
\text { Score }\end{array}$ & $\begin{array}{c}\text { Post-test } \\
\text { Score }\end{array}$ & & $\begin{array}{c}\text { Pre-test } \\
\text { Score }\end{array}$ & $\begin{array}{c}\text { Post-test } \\
\text { Score }\end{array}$ \\
\hline Student 1 & 20 & 34 & Student 1 & 30 & 37 \\
\hline Student 2 & 23 & 25 & Student 2 & 13 & 22 \\
\hline Student 3 & 25 & 33 & Student 3 & 11 & 28 \\
\hline Student 4 & 23 & 25 & Student 4 & 23 & 30 \\
\hline Student 5 & 22 & 28 & Student 5 & 17 & 31 \\
\hline Student 6 & 16 & 12 & Student 6 & 15 & 25 \\
\hline Student 7 & 21 & 31 & Student 7 & 15 & 21 \\
\hline Student 8 & 7 & 18 & Student 8 & 12 & 18 \\
\hline Student 9 & 8 & 22 & Student 9 & 16 & 21 \\
\hline Student 10 & 22 & 31 & Student 10 & 17 & 30 \\
\hline Average & 18.7 & 25.9 & & 16.9 & 26.3 \\
\hline $\begin{array}{l}\text { Standard } \\
\text { Deviation }\end{array}$ & 6.4 & 7.0 & & 5.4 & 5.6 \\
\hline
\end{tabular}


Figure 1. Control Group Individual Student Pre- to Post-test Change (Multiple-choice test)

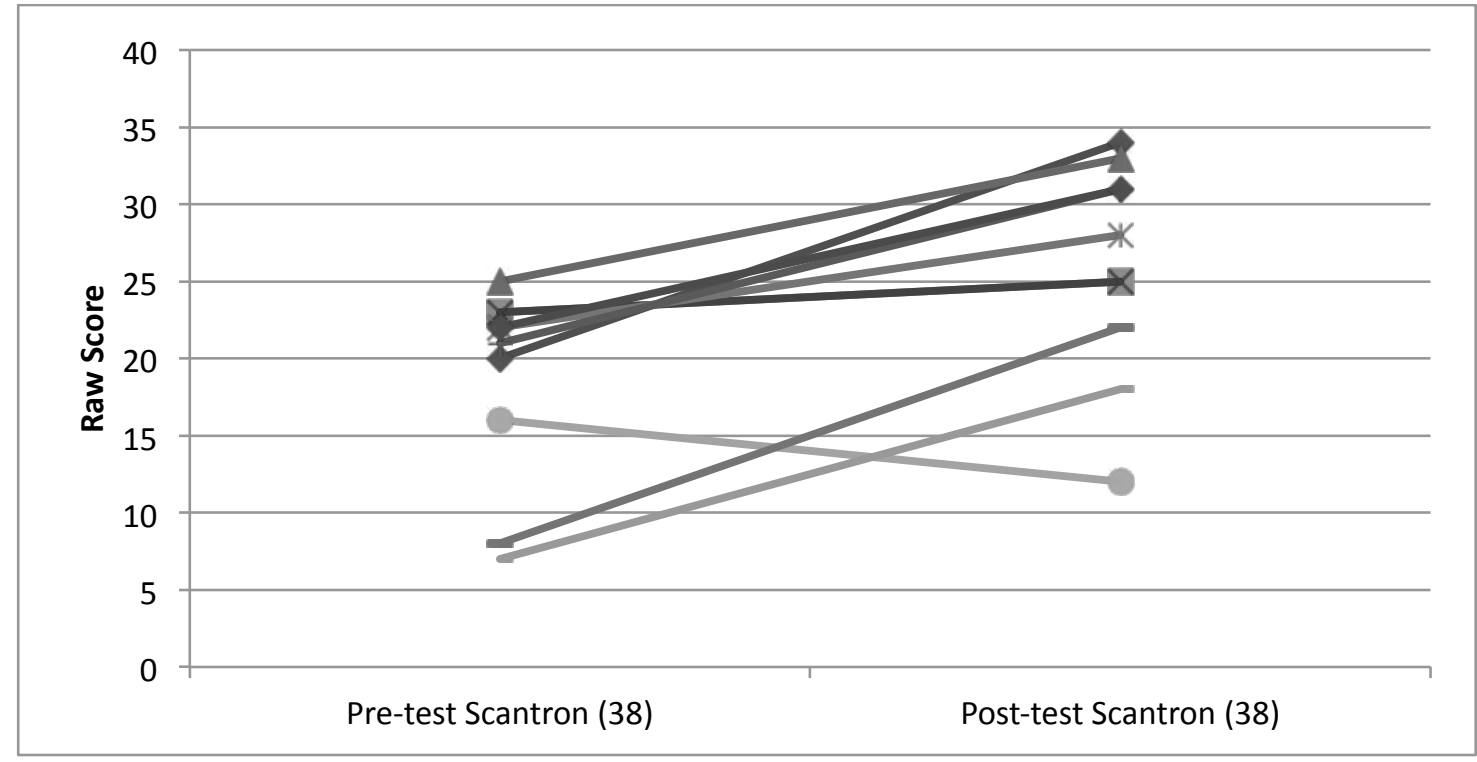

Figure 2. Experimental Group Individual Student Pre- to Post-test Change (Multiple-choice test)

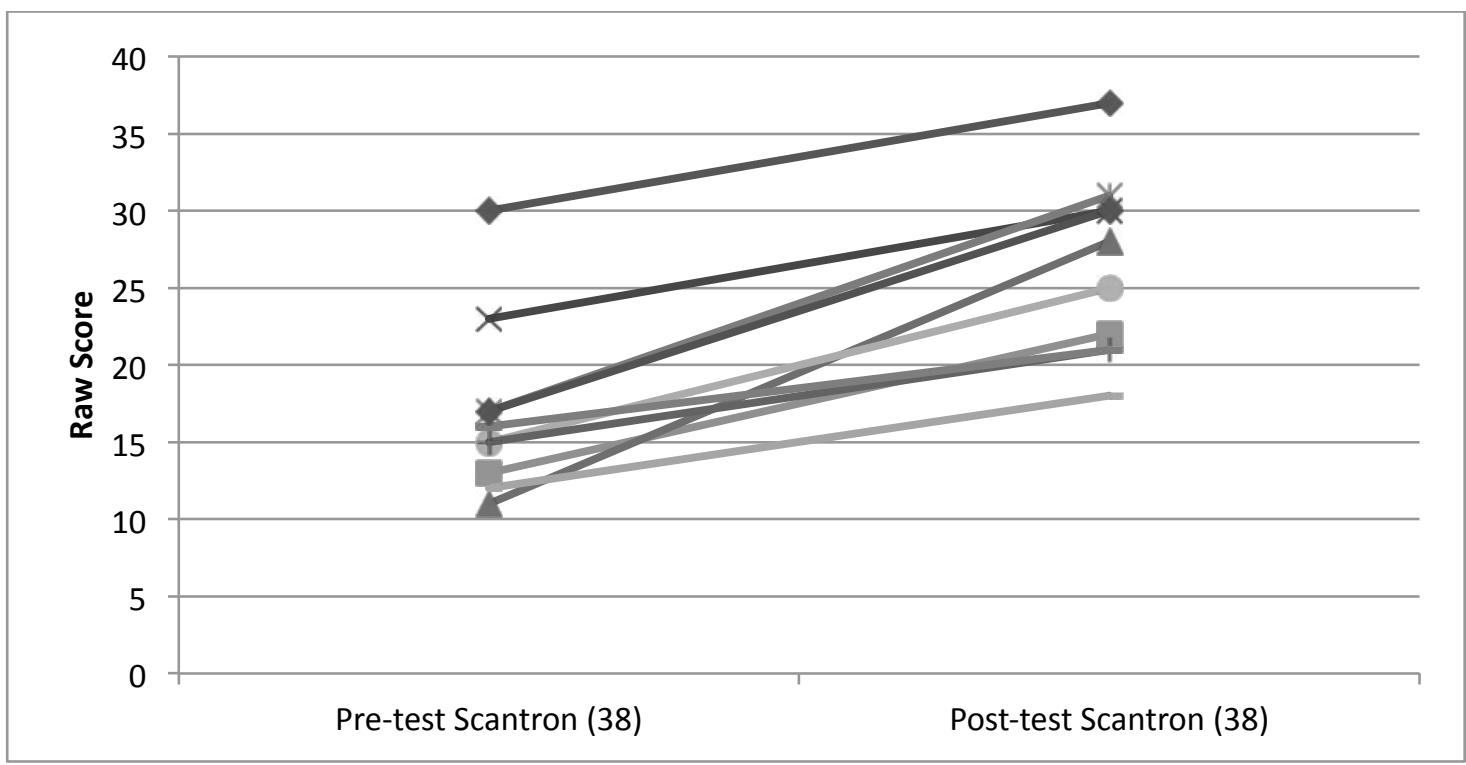


Constructed Response Test. Gains in knowledge also occurred in the control and experimental classes for the constructed response section of the test ( 3 items for 15 total points possible). The majority of students showed improvement from the pre-test to the post-test (Table 11, Figures 3 and 4).

Table 11. Students Pre-test and Post-test Constructed Response Test Score

\begin{tabular}{|c|c|c|c|c|c|}
\hline \multicolumn{3}{|c|}{ Control } & \multicolumn{3}{|c|}{ Experimental } \\
\hline & $\begin{array}{c}\text { Pre-test } \\
\text { Score }\end{array}$ & $\begin{array}{c}\text { Post-test } \\
\text { Score }\end{array}$ & & $\begin{array}{c}\text { Pre-test } \\
\text { Score }\end{array}$ & $\begin{array}{c}\text { Post-test } \\
\text { Score }\end{array}$ \\
\hline Student 1 & 3 & 13 & Student 1 & 8 & 14 \\
\hline Student 2 & 1 & 9 & Student 2 & 1 & 13 \\
\hline Student 3 & 0 & 11 & Student 3 & 0 & 8 \\
\hline Student 4 & 2 & 5 & Student 4 & 1 & 9 \\
\hline Student 5 & 2 & 3 & Student 5 & 1 & 12 \\
\hline Student 6 & 0 & 4 & Student 6 & 0 & 9 \\
\hline Student 7 & 2 & 11 & Student 7 & 0 & 13 \\
\hline Student 8 & 0 & 3 & Student 8 & 0 & 10 \\
\hline Student 9 & 2 & 8 & Student 9 & 0 & 11 \\
\hline Student 10 & 3 & 11 & Student 10 & 0 & 11 \\
\hline Average & 1.5 & 7.8 & & 1.1 & 11.0 \\
\hline $\begin{array}{l}\text { Standard } \\
\text { Deviation }\end{array}$ & 1.2 & 3.8 & & 2.5 & 2.0 \\
\hline
\end{tabular}


Figure 3. Control Group Individual Student Pre- to Post-test Change (Constructed Response test)

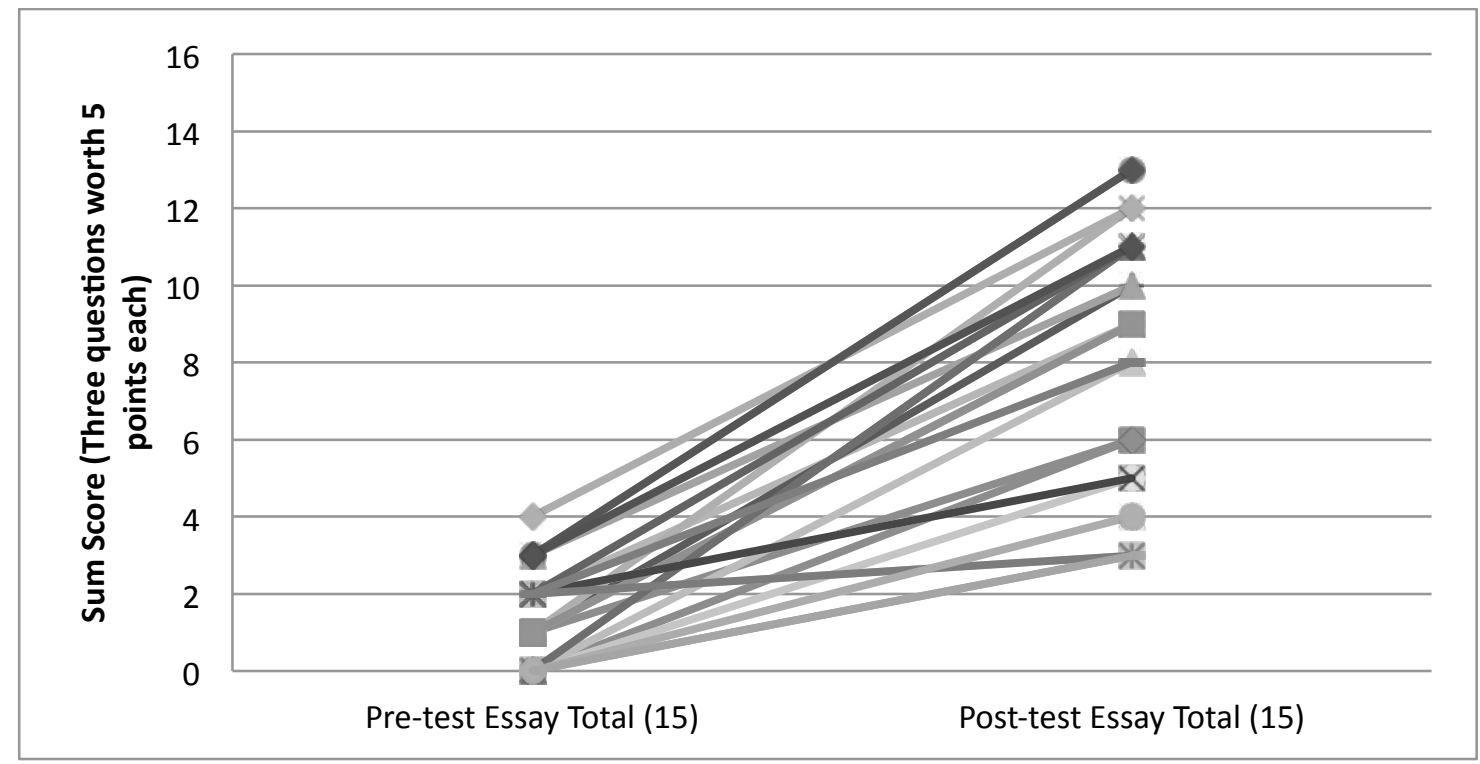

Figure 4. Experimental Group Individual Student Pre- to Post-test Change (Constructed Response test)

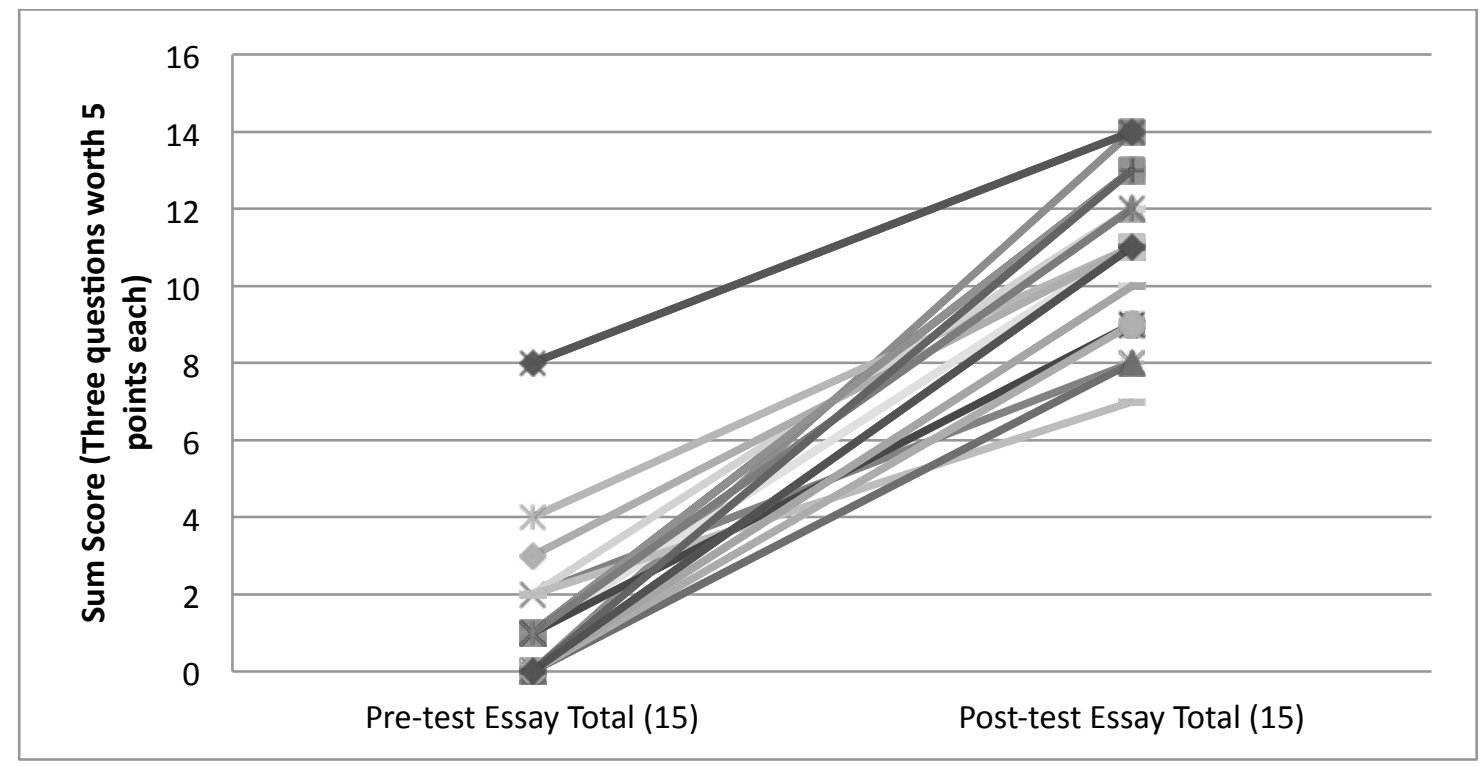


Students' Gains. Students' change in knowledge was also analyzed by looking at the gain from the pre-test to the post-test (Table 12). The average gains in the experimental and control groups were statistically compared using a t-test. The t-test determines whether the averages of two groups are statistically different from each other. Using the t-test helped provide a valuable measure of the impacts of the real-world content curriculum that was implemented in the experimental group.

\section{Table 12. Pre-test and Post-test Percent Gain by Matched Experimental/Control Subjects}

\begin{tabular}{cccc}
\hline \multirow{2}{*}{ Class } & \multirow{2}{*}{$\mathrm{N}$} & Multiple Choice & Constructed Responses \\
\cline { 3 - 4 } & & Gain (\%) & Gain (\%) \\
\hline Control & 10 & $7.2(54.2)$ & $6.3(415.0)$ \\
Experimental & 10 & $9.4(62.4)$ & $9.9(937.5)$ \\
\hline Average & & $8.3(58.3)$ & $8.1(676.3)$ \\
Standard Deviation & $5.0(51.8)$ & $3.3(417.3)$ \\
\hline $\begin{array}{c}\text { Note. Probability associated with a Student's two-sample equal variance t-Test, with a two-tailed distribution (Multiple Choice: 0.336; } \\
\text { Constructed Responses: 0.011) }\end{array}$
\end{tabular}

The control group increased their score by $54.2 \%$ on the multiple choice section of the test; the experimental group increased by $62.4 \%$ on the same section. The difference in gain from pre-test to post-test on the multiple-choice section between the control and experimental group was not significant (t-test: 0.336$)$. On the constructed response section of the test, the control group improved their performance by $415.0 \%$; the experimental group improved by $937.5 \%$. The difference in gain from pre-test to post-test on the constructed response section between the control and experimental matched subjects was statistically significant (t-test: 0.011 ), with the experimental group showing greater improvement. 


\section{Clinical Interviews}

Clinical interviews were conducted on a random sample of 7 students from the control $(\mathrm{N}=3)$ and experimental $(\mathrm{N}=4)$ matched subjects (Table 13). These interviews allowed for further analysis of students' knowledge and understanding and helped establish the nature of the significant difference detected using the t-test. Excerpts are included to demonstrate examples of students' level of understanding.

Table 13. Summary of Clinical Interview Data

\begin{tabular}{|c|c|c|c|c|c|c|c|c|c|}
\hline $\begin{array}{l}\text { Inter- } \\
\text { view } \\
\text { Item }\end{array}$ & $\begin{array}{c}\text { Cog } \\
\text { Level }\end{array}$ & $\mathrm{P}^{1}$ & $\mathrm{D}^{2}$ & Class & $\mathrm{n}$ & $\begin{array}{c}\quad \# \\
\text { Correct } \\
\text { (Pretest) }\end{array}$ & $\begin{array}{c}\# \\
\text { Correct } \\
\text { (Posttest) }\end{array}$ & $\begin{array}{c}\# \\
\text { Correct } \\
\text { (Interview) }\end{array}$ & $\begin{array}{c}\# \\
\text { Correct } \\
\text { (Int Details \& Support) }\end{array}$ \\
\hline \multirow{2}{*}{46} & \multirow{2}{*}{ Know } & \multirow{2}{*}{0.45} & \multirow{2}{*}{0.40} & Control & 3 & 0 & 1 & 0 & 0 \\
\hline & & & & Experimental & 4 & 1 & 2 & 3 & 4 \\
\hline \multirow{2}{*}{11} & \multirow{2}{*}{ Comp } & \multirow{2}{*}{0.84} & \multirow{2}{*}{0.07} & Control & 3 & 3 & 2 & 3 & 0 \\
\hline & & & & Experimental & 4 & 4 & 3 & 4 & 2 \\
\hline \multirow[b]{2}{*}{ - } & \multirow{2}{*}{ Syn } & \multirow[b]{2}{*}{ - } & \multirow[b]{2}{*}{-} & Control & 3 & - & - & 0 & 0 \\
\hline & & & & Experimental & 4 & - & - & 2 & 2 \\
\hline
\end{tabular}

The first part of the interview dealt with item \#46 from the pre-test and post-test (Appendix A). Item analysis showed the difficulty and discrimination to be 0.45 and 0.40 , respectively (Tables 8 and 9). This item was considered a "knowledge" level question according to Bloom's Taxonomy in the Cognitive Domain (Table 7):

46. Sustainability is described as:

a. the study of diversity in ecology.

$b$. the ability to fulfill your own personal needs, without regards to the overall human population and its future.

c. giving up all material belongings.

$* d$. the ability to fulfill human needs in a way that allows the human population to survive indefinitely. 
Three students (two from experimental, one from control) answered this item with the correct answer of D on the post-test; two students chose B, one student chose A, and one student did not answer the question. When asked orally, three students, all from the experimental group, chose the correct answer of D, with one giving the reason "I remember for our 'footprint,' it said something about the ability, like how to choose your needs. I believe it said the materials will help you and save energy and water.” Three students (one from experimental, two from control) chose B, which all seven interviewees voiced agreement that the answer B was similar to the correct answer of D. One student expressed her feelings with: “Actually, I wasn't sure to pick between b and d, because they're kinda (sic) of...to me they both have like their needs in a way that allows them for the population of them." Two students interestingly chose B due to the fact that they thought the "human population wouldn't survive indefinitely." One student, from the control group, chose A, admitting that she had to guess based on which one "looked the best."

All seven students interviewed were able to provide correct details towards the meaning of the vocabulary terms involved in the question ("sustainability", "ecology", "diversity", and "population"), regardless of which answer they chose. A student in the experimental group (JT) was on the way to relating the term to the "big picture" by discussing the real-world content of sustainability in their own life and applying the term to a theoretical situation. In comparison, a student from the control group (NZ) offered a vague definition and was unable to apply an example. 
JT (Experimental): "Sustainability to me means like how to fulfill your own personal needs and goals. Like if you make a house, you try to find and if you took away animal's homes, try to find them a new home the best you can because you shouldn't take their own homes away."

NZ (Control): "To like fulfill something, the ability to sustain something. (Teacher: Can you provide an example?) Maybe, but not likely."

When interviewed, the experimental group were able to provide answers with detailed examples. The control group, whether they gave correct answers or not, were unable to supply detailed examples to the interview questions. The following excerpt, where students were asked a question from the pre/posttest, helps support this conclusion:

JG (Experimental): "I think it's D. Because when we're working... when you gave us this one sheet of paper, I remember for our 'footprint,' it said something about the ability, like how to choose your needs. I believe it said the materials will help you and save energy and water."

SB (Control): "Umm...A. Well I kinda (sic) of just guessed on what looked the best or sounded the best."

The example student in the experimental class (JG) was able to remember specific real-world content (ecological footprint) and apply it, helping them to answer the question acceptably. The student from the control class (SB), albeit answering the question incorrectly, was unable to support the answer with any specific details, despite prompting from the interviewer.

The following excerpt, where students were asked a question about the word "ecology" also supports the conclusion that students from the experimental group were able to provide answers with detailed examples: 
JG (Experimental): "It means like...umm...like the whole unit we're working on is like ecology. It's like studying that. We looked at our footprints, we looked at animals like the trout and how the food chain and all of that works."

SB (Control): "I don't know, it kinda (sic) of reminds me of ecosystems I guess. Because the "eco" in ecology. When I look at the word I guess it just makes me think of Earth I guess or woods by a lake or something."

The example student in the experimental class (JG) was able to remember specific real-world content (trout and food chain) and apply it to the overall meaning of ecology, helping them to answer the question acceptably. The student from the control class (SB) recognized part of the word ("eco") and tried to relate it to another word (ecosystem), but when prompted by the interviewer to support the answer with specific details, was only able to provide a general example (Earth or woods by a lake).

The second part of the interview dealt with item \#11 from the pre-test and posttest. Item analysis showed the difficulty and discrimination to be 0.84 and 0.07 , respectively (Tables 8 and 9). This item was considered a "comprehension" level question according to Bloom's Taxonomy in the Cognitive Domain (Table 7):

11. An ecosystem consists of

a. a community of organisms.

b. energy.

c. the soil, water, and weather.

*d. all of the above.

Five students (three from experimental, two from control) answered this item with the correct answer of D on the post-test; two students chose A. When asked orally, all seven students chose the correct answer of D, echoing each other that an ecosystem consists of each of the characteristics, and that "all are important." Two of the students, 
both of whom were in the experimental group, were able to provide specific reasons why an ecosystem must contain each of the characteristics. An example reason was: "Energy fits in like because the plants produce their own energy and if they grow bigger and bigger, deer and moose can eat them so that way they can survive on their own."

All seven of those interviewed were able to provide correct details towards the meaning of the vocabulary terms involved in the question ("ecosystem", "community", "abiotic", and "biotic"). The experimental students were able to apply the vocabulary term to real-world content, understanding it better as a result. The following excerpt centered on vocabulary; the student was asked what the specific term ("ecosystem") meant to them and if they could come up with an example of it.

JG (Experimental): “A family of organisms. Umm...like a group or habitat of animals and how it works. We looked at a beach with an ocean and a pond and birds, a beach ecosystem (from the posters)."

SB (Control): "Like life I guess... and like everything in it. A bird in a forest."

The third part of the interview was based on an ecology concept. The activity would be considered at the "synthesis" level according to Bloom's Taxonomy in the Cognitive Domain:

1. Provide student with six words (osprey, trout, minnow, caddisfly, phytoplankton, algae, crayfish) related to food chain (written in big letters on separate 1" $\mathrm{x} 2$ " slips of paper). Ask student to arrange the words on a piece of paper and draw lines to show words that are related.

All seven students interviewed attempted to put together a food chain from the provided words, with two students (both from experimental group) completing it correctly. Six of the students (three from experimental group, three from control group) 
agreed that the top-level consumer was the "osprey", with five students agreeing on the order of "minnow $\rightarrow$ trout $\rightarrow$ osprey". All seven students placed "algae" at the base of the food chain, with one student (experimental group) including the additional idea that the "sun" was vital for energy production. After the agreement with the placement of "algae," there was more discourse at the producer and primary consumer level of the food chain. There were several different orders with "phytoplankton", "caddisfly", and "crayfish". None of the students described the decomposer role of the "crayfish" in the specific food chain, with only two students (both from experimental group) describing that the "crayfish" would obtain energy from the "minnow".

All seven of the interviewed students were able to provide correct details towards the meaning of the vocabulary terms involved in the question ("food chain", "energy transfer", “producer”, “consumer”, “decomposer”, “competition”, “parasitism”, and "predator/prey"), with the exception of the term "symbiosis". Only two students (both from experimental group) were able to describe "symbiosis", with one student providing the example: "symbiosis to me is like kind of like something helps out another, say like a tree and a human. The tree helps the human because the tree gives off $\mathrm{O}_{2}$ and the human needs $\mathrm{O}_{2}$. But the human gives off $\mathrm{CO}_{2}$ and the trees need it, so it kind of works out both ways." The sample of students in the experimental group were able to apply the vocabulary term to real-world content, as seen in the following excerpt where the student was asked about the term "food chain". 
JJ (Experimental): "Food chain is kind of like a food source to whatever is the predator or prey; both of them have energy to me, and both of them are food, or they can eat food easily. It kind of like a chain that can go around and around... and possibly never stop."

BV (Control): "The ways that it lives, and how what the ecosystem...like how it is living."

The clinical interviews allowed for further analysis of students' knowledge and understanding of ecology concepts by providing an effective means of assessment. 


\section{Chapter 5 - Conclusion}

\section{Overview}

The Michigan Department of Education states that deep knowledge is where "instruction addresses central ideas of a topic or discipline with enough thoroughness to explore connections and relationships and to produce relatively complex understanding" (2007, p. 6). After analyzing all of the data from my ecology unit, I have come to the conclusion that the unit as taught was successful, with evidence showing that students in both the experimental and control groups showed large gains from the pre-test given prior to the ecosystem unit to the post-test given at the unit's conclusion, in both the multiplechoice and constructed response form. The ecology unit with the implementation of realworld content [trout] in my science classroom was even more successful, and improved students' deep knowledge of ecosystem content from Michigan's Department of Education Grade Level Content Expectations. The gains by the experimental group on the constructed response section, which included higher cognitive level items, were significant. Clinical interviews after the post-test confirmed increases in deep knowledge of ecosystem concepts in the experimental group, by revealing that a sample of experimental group students had a better grasp of important ecology concepts as compared to a sample of control group students. 


\section{Multiple-choice Assessments}

On the multiple-choice section of the test, students increased their scores by $54.2 \%$ in the control group and $62.4 \%$ in the experimental group. The differences were not statistically significant (t-test: 0.336 ), but greater improvements in the experimental group seem to indicate a positive impact from the implementation of real-world content. There is always a possibility that the effectiveness of a multiple-choice assessment can be limited by students guessing on answers, but the completion of an item discrimination analysis, and subsequent removal of test items, helped reduce this possibility. Still, this could have been the reason for the fact that there was not a statistical difference between the control and experimental group. The multiple-choice test did indicate that students gained knowledge relating to the $6^{\text {th }}$ grade level content expectations, showing that the unit as taught was successful.

\section{Constructive Response Assessments}

On the constructed response section of the test, the control group improved their performance by $415.0 \%$, while the experimental group improved by $937.5 \%$. The difference in gain from pre-test to post-test on the constructed response section between the control and experimental matched subjects was statistically significant (t-test: 0.011$)$, with the experimental group showing greater improvement. This is important, as it indicates that the implementation of real-world content in the experimental group made a significant impact. 
The use of real-world content [trout] allowed the students in the experimental group to better understand ecosystem concepts. Bloom's taxonomic levels include "analysis" and "synthesis" at the higher end of the spectrum, which was specifically tested in the constructed response portion of the assessment (Table 7 and Appendix A). The students in the experimental group understood concepts at a higher level and were able to develop "deep knowledge" as described in the focus question. This was made evident in not only the significant improvements in rubric scores, but also in the specific details that were included in the constructed responses (Appendix K).

\section{Clinical Interviews}

Differences in the level of student understanding between the control and experimental groups were evident in the clinical interviews (Appendix L). The experimental students were better able to apply knowledge to the "greater world" within, as well as beyond, our rural community, which I stated as the definition of "real-world content." This helped support the evidence from the multiple-choice and constructed response sections of the post-test.

The clinical interviews provided valuable evidence towards answering my research question of "What is the effect of implementing real-world content on students' deep knowledge?" Students in the experimental group, where real-world content was incorporated into the curriculum, understood the material well enough to be able to provide detailed examples that supported their answer in several instances. Students in the control group, when asked the same questions as the students in the experimental group, were unable to provide the level of detail to support their answer in several cases. 


\section{Problems and Improvements}

A majority of the unit went as planned, with implementation and analysis completed successfully overall. One problem encountered dealt with time constraints, including the amount of time that it took to carry out the unit. I would suggest that teachers develop and follow a year-long plan, as well as more detailed weekly plans, in accordance with the MI Curriculum Framework. I always attempt to do this with each of the classes that I teach, and it seems to be a dynamic process with each school year. This is likely a common conclusion, considering that the State of Michigan recently updated its standards to include fewer "key" standards. Following a plan is important in order to ensure that the standards are taught and that students have an opportunity to reach their potential.

Rearing trout in a classroom setting resulted in some logistical issues as well. With the common lack in supply money available for the classroom, the acquisition of grant money is vital to allow this project to work. Providing this project for my students was something that I felt very strongly about, which helped motivate me to obtain a substantial grant in order to provide the supplies necessary to run the project. The supplies cost about $\$ 1500$ to purchase, but will last many years, and will impact many students.

There was a possibility that the results could have been affected by the "Hawthorne effect," which predicts improvement in subjects merely for the reason that they are being studied (Jones, 1992; Landsberger,1958; McCarney et. al., 2007). All students did agree to be part of the study via an informed consent letter that had to be 
signed by both the student and a parent/guardian (Appendix N). The students did not know what group (control or experimental) they were assigned. All students were treated in the same manner, with the exception of the implementation of the real-world content of rearing trout in the experimental class. There were several instances over the course of the study where media came in to cover the project, which could have boosted the productivity of the students as per the Hawthorne effect. The media opportunities were made available to both the control and experimental classes. A majority of the students showed improvement from the pre-test to the post-test, but there was no significant difference between the control and experimental class in some forms of the test.

Separating the control and experimental groups in classic experimental dichotomy proved somewhat difficult. I did not want to create a setting where I limited my control group students to only reading out of a textbook (I don't use a textbook in middle school) and filling out ineffective worksheets. I try to incorporate real-world content in each of my classes, and have since I began teaching. This may have blurred the differences between the control and experimental curriculums, but ensuring that all of my students learn to their fullest potential was, and always will be, one of my most important educational goals. Although all of the activities between the control and experimental classes were not different, the incorporation of trout as specific real-world content did show a significant impact. I know that I will fully incorporate the real-world content of rearing trout where appropriate in all of my future classes. 


\section{Educational Implications}

Staying up with as well as performing research is an important responsibility of an effective educator. With the changing environments that students come from and learn in, using research-based methods will help ensure that students meet their fullest potential.

Many people including students, fellow educators, and community members, personally thank me for implementing real-world content in my science classroom. The project where my students and I reared trout in the classroom was another example of this, as it brought a positive environment to the school and those involved in the project (Appendix M).

I always thought that relating concepts to students' lives was beneficial. It is part of my goal to prepare them for the world outside of my classroom. Completing this research project has proven to me, as well as those that review my research, that implementing real-world content is vital to a science curriculum. 


\section{References}

Akerson, V. L., \& Abd-El-Khalick, F. (2003). Teaching Elements of Nature of Science: A Yearlong Case Study of a Fourth-Grade Teacher. Journal of Research in Science Teaching, 40(10). 1025-1049.

Bouillion, L. M., \& Gomez, L. M. (2001). Connecting School and Community with Science Learning: Real World Problems and School-Community Partnerships as Contextual Scaffolds. Journal of Research in Science Teaching, 38(8), 878-898.

Bowyer, J. B., \& Linn, M. C. (1976). Proceedings from the annual meeting of the American Educational Research Association '76: An Experiment in Curriculum Evaluation: Science Curriculum Improvement Study and Scientific Literacy. San Francisco, CA.

Boyer, J. B., \& Linn, M. C. (1978). Effectiveness of the Science Curriculum Improvement Study in Teaching Scientific Literacy. Journal of Research in Science Teaching, 15(3), 209-219.

Bybee, R., McCrae, B., \& Laurie R. (2009). PISA 2006: An Assessment of Scientific Literacy. Journal of Research in Science Teaching, 46(8), 865-883.

Carey, S., Evans, R., Honda, M., Jay., \& Unger, C. (1989). 'An experiment is when you try it and see if it works': a study of grade 7 students' understanding of the construction of scientific knowledge. International Journal of Science Education, 11, 514-529.

Carlson, J. L. (2008). Effect of Theme-Based, Guided Inquiry Instruction on Science Literacy in Ecology (Unpublished master's report). Michigan Technological University, Houghton, MI.

Champagne, A. B., \& Newell, S. T. (1992). Directions for Research and Development: Alternative Methods of Assessing Scientific Literacy. Journal of Research in Science Teaching, 29(8), 841-860.

Chin, C., \& Brown, D. E. (2000). Learning in Science: A Comparison of Deep and Surface Approaches. Journal of Research in Science Teaching, 37(2), 109-138.

Collins, A. (1997). National science education standards: looking backward and forward. The Elementary School Journal, 97(4), 299-313. 
Crawford, B. A. (2000). Embracing the Essence of Inquiry: New Roles for Science Teachers. Journal of Research in Science Teaching, 37(9), 916-37.

Cunningham, G. (1986). Educational and psychological measurement. New York: Macmillan.

DeBoer, G. E. (2000). Scientific Literacy: Another Look at Its Historical and Contemporary Meanings and Its Relationship to Science Education Reform. Journal of Research in Science Teaching, 37(6), 582-601.

Dewey, J. (1902). The child and the curriculum. Chicago: University of Chicago Press.

Education, M. S. B. o. (2006). High School Science Content Expectations. Lansing, MI: Michigan Department of Education

Education, M. S. B. o. (2009). MDE - Grade Level Content Expectations. Lansing, MI: Michigan Department of Education.

Education, M. S. B. o. (1996). Michigan Curriculum Framework. Lansing, MI: Michigan Department of Education.

Education, M. S. B. o. (2007). Michigan Standards for Teaching and Learning. Michigan Department of Education.

Education, U.S.D.o. (2010). National Assessment of Educational Progress (NAEP). Retrieved November 29, 2010, from http://nces.ed.gov/nationsreportcard/about/

Feinstein, N. (2011). Salvaging Science Literacy. Science Education, 95(1), 168-185.

Finley, F. N. (1986). Evaluating Instruction: The Complimentary Use of Clinical Interviews. Journal of Research in Science Teaching, 23(7), 635-650.

Fraser-Abder, P. (2005). Towards Scientific Literacy for All: An Urban Science Teacher Education Model.

Gersten, R., \& Baker, S. (1998). Real World Use of Scientific Concepts: Integrating Situated Cognition with Explicit Instruction. Exceptional Children, 65(1), 23-35.

Hotchkiss, R., \& Dickerson, D. (2008). A Remote-Sensing Mission. Science and Children, 45(5), 44-49.

Hurd, P. D. (1998). Scientific Literacy: New Minds for a Changing World. Science Education, 82(3), 407-416. 
Isaac, S., \& Michael, W. B. (1995). Handbook in Research and Evaluation. San Diego, CA: Educational and Industrial Testing Services.

Jones, S.R.G. (1992). Was There a Hawthorne Effect? American Journal of Sociology, 98(3). 451-468.

Kemp, A. C. (2000). Proceedings from the annual meeting of National Association for Research in Science Teaching '00: Science Educator's Views on the Goal of Scientific Literacy for All: An Interpretive Review of the Literature. New Orleans, LA.

Kesidou S., \& Roseman, J. E. (2002). How Well Do Middle School Science Programs Measure Up? Findings from Project 2061's Curriculum Review. Journal of Research in Science Teaching, 39(6). 522-549.

Kolsto, S. D. (2001). Scientific Literacy for Citizenship: Tools for Dealing with the Science Dimension of Controversial Socioscientific Issues. Science Educator, 85(3), 291-310.

Korpan, C. A., Bisanz, G. L., Dukewich, T. L., Robinson, K. M., Bisanz, J., Thibodeau, M. H., Hubbard, K. E., \& Leighton, J. P. (1994). Assessing Scientific Literacy: A Taxonomy for Classifying Questions and Knowledge About Science Research (Technical Report No. 94-1). Edmonton: Centre for Research in Child Development.

Korpan, C. A., Bisanz, G. L., Bisanz, J., \& Henderson, J. M. (1997). Assessing Literacy in Science: Evaluation of Scientific News Briefs. Science Education, 81(5), 515532.

Landsberger H.A. (1958). Hawthorne Revisited. Ithaca, NY: Cornell University.

Lung, M. (1999). A Thematic Approach: Making a Biology Course Relevant and Process-Oriented. American Biology Teacher, 61(1), 18-22.

McCarney, R., Warner, J., Iliffe, S., Haselen, R.V., Griffin, M., \& Fisher, P. The Hawthorne Effect: a randomized, controlled trial. BMC Medical Research Methodology, 7(30).

McCarthy, C. B. (2005). Effects of thematic-based, hands-on science teaching versus a textbook approach for students with disabilities. Journal of Research in Science Teaching, 42(3), 245-263.

McComas, W. F., Almazroa, H., \& Clough, M. P. (1998). The Nature of Science in Science Education: An Introduction. Science and Education, 7(6), 511-32. 
Mitman, A. L., Mergendoller, J. R., Packer, M. J. \& Marchman V. A. (1984). Scientific Literacy in Seventh Grade Life Science: A Study of Instructional Process, Task Completion, Student Perceptions, and Learning Outcomes. Final Report of the Intermediate Life Science Study. Secondary Science and Mathematics Improvement Program. San Francisco, CA: Far West Laboratory.

National Research Council. (1996). National science education standards. Washington, DC: National Academy Press.

National Science Teachers Association. (1971). School Science Education for the 1970s. Washington, DC.

National Science Teachers Association. (1982). Science-technology society: Science Education for the 1980s. Washington, DC.

Posner, G. J., \& W. A. Gertzog. (1982). The Clinical Interview and the Measurement of Conceptual Change. Science Education, 66(2). 195-209.

Postlethwait, J. H., \& Hopson, J. L. (2006). Modern Biology. Austin, TX: Holt, Rinehart, and Winston.

Rivet, A. E., \& Krajcik, J. S. (2004). Achieving Standards in Urban Systematic Reform: An Example of a Sixth Grade Project-Based Science Curriculum. Journal of Research in Science Teaching, 41(7). 669-692.

Scardamalia, M., \& Bereiter, C. (2006). Knowledge building: Theory, pedagogy, and technology. In K. Sawyer (Ed.), Cambridge Handbook of the Learning Sciences (pp. 97-118). New York: Cambridge University Press.

The Nation's Report Card. (2005). NAEP 2005 Assessment Results - Science: State Result: State Achievement Levels. Retrieved November 17, 2010, from http://www.nationsreportcard.gov/science_2005/s0106.asp?tab_id=tab1\&subtab_i $\mathrm{d}=$ Tab 1 \#chart

The Nation's Report Card. (2009). Science 2009. Retrieved July 2, 2011, from http://nces.ed.gov/nationsreportcard/pdf/main2009/2011451.pdf

Timmons, L. S., Hansen, P. A., \& Raymond, T. G. (2009). Assessment of Anchorage School District Students Participating in the Salmon in the Classroom Program, 2006-2007. (Fishery Data Series No. 09-20). Anchorage, AK: Alaska Department of Fish and Game. 
Worthen, B., White, K., Fan, X., \& Sudweeks, R. (1999). Measurement and assessment in schools $\left(2^{\text {nd }}\right.$ ed. $)$. New York: Addison Wesley Longman.

Zolynsky, D. L. (2007). Motivating Students to Become Scientific Literate Through Inquiry (Unpublished master's report). Michigan Technological University, Houghton, MI.

Zuzovsky, R. (1997). Assessing Scientific and Technological Literacy Among Sixth Graders in Israel. Studies in Educational Evaluation, 23(3), 231-256. 
This page deliberately blank 


\section{Appendix A. Pre- and Post-test and Answer Key}

\section{Ecology PrePostTest}

\section{Multiple Choice}

Identify the choice that best completes the statement or answers the question.

1. The study of the interaction of living organisms with each other and with their physical environment is called
a. health.
b. economy.
c. ecology.
d. geology.

2.

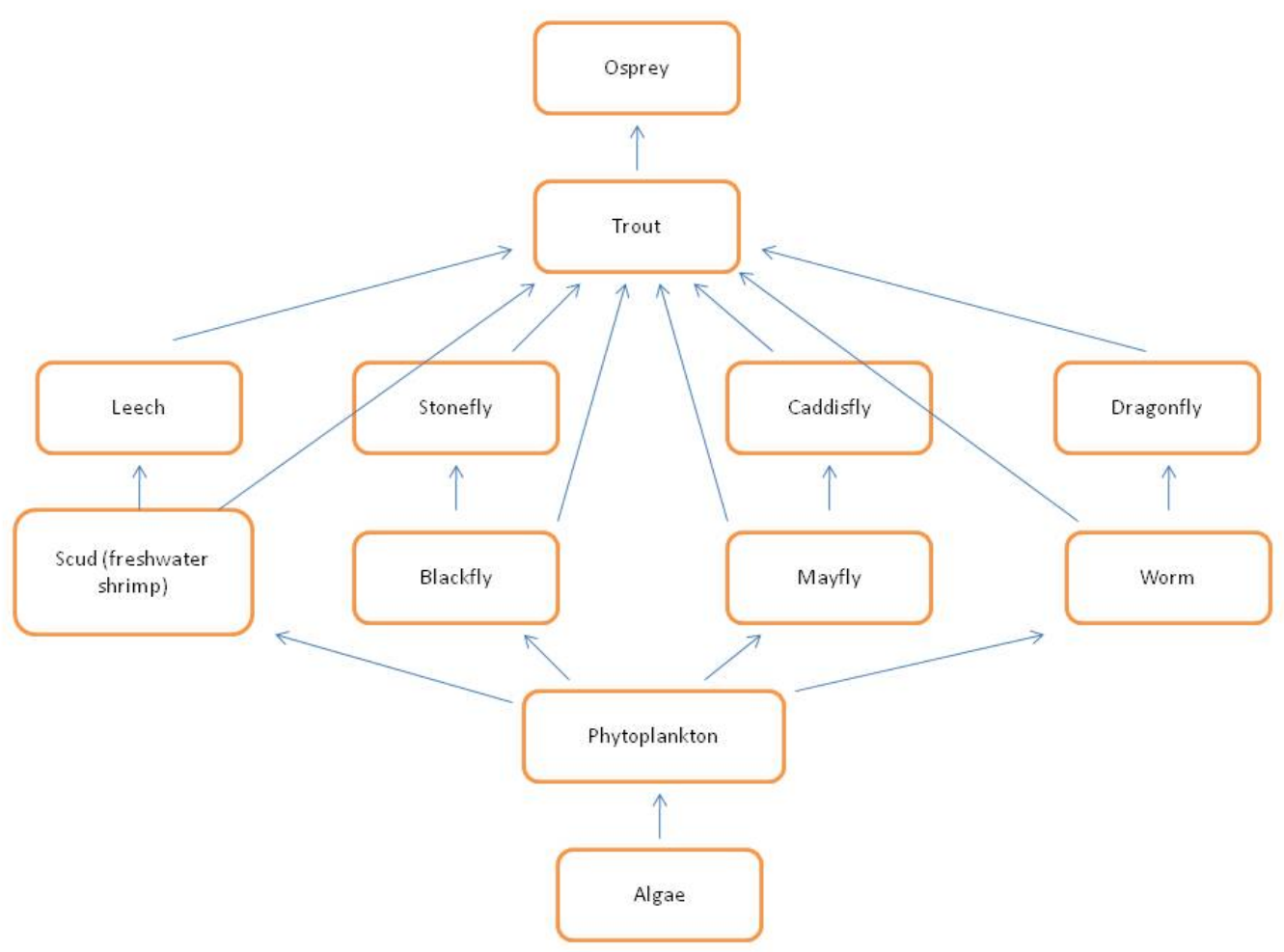

Refer to the illustration above. The diagram, which shows how energy moves through an ecosystem, is described as a:
a. habitat net.
b. food chain.
c. trophic level.
d. food web. 
3. Refer to the illustration above. The photosynthetic algae are:
a. producers
b. consumers
c. parasites
d. decomposers

4. Refer to the illustration above. The trout are
a. producers.
b. consumers.
c. parasites.
d. decomposers.

5. Refer to the illustration above. Among all of the food chains, the organisms at the highest trophic level are classified as:
a. consumers (phytoplankton).
b. consumers (trout).
c. consumers (scud).
d. consumers (osprey).

6. Organisms that manufacture organic nutrients for an ecosystem are called
a. consumers.
b. predators.
c. producers.
d. omnivores. type?

7. In a food web, which type of organism receives energy from every other
a. producer
b. carnivore
c. decomposer
d. All of the above

8. If a deer in a forest is classified as an herbivore, then the wolf that eats the deer is classified as a(n)
a. consumer
b. producer
c. trophic level
d. decomposer 
9. Bacteria that break down dead tissue, and serve as "recyclers," are known

as
a. detritivores
b. decomposers
c. consumer
d. producers

10. All organisms in an ecosystem are linked together in a network of interactions. This quality is called
a. geochemical processes.
b. isolation.
c. interdependence.
d. communication.

11. An ecosystem consists of
a. a community of organisms.
b. energy.
c. the soil, water, and weather.
d. All of the above

$\overline{\text { place }}$ is called a

12. A group of organisms of different species living together in a particular
a. community.
b. population.
c. biome.
d. habitat.

13. A group of the same species living together in a particular place is called a
a. community.
b. population.
c. biome.
d. habitat.

14. Identify which of the following does not represent a population?
a. all the robins in Austin, Texas
b. all the grass frogs in the pond of Central Park in New York City
c. all the birds in Chicago, Illinois
d. all the elk in Yosemite National Park

15. Demographic studies of populations must take into consideration
a. population size.
b. population density.
c. population dispersion.
d. All of the above 
16. A population of organisms grows

a. with no natural restrictions except the availability of food.

b. when the birth rate exceeds the death rate.

c. only in the absence of predators or natural diseases.

d. All of the above

17. An organism's niche is described as:

a. what it eats.

b. where it eats.

c. when it eats.

d. All of the above

18. All organisms in an ecosystem are linked together in a network of interactions, which can be described by the following term:
a. geochemical processes.
b. isolation.
c. interdependence.
d. communication.

19. The of an organism includes its habitat, its feeding habits, other aspects of its biology, and its interactions with other organisms and with the environment.
a. job
b. ecology
c. duty
d. niche

20. A change (however small) in the population size of one species can affect the entire ecosystem due to the world's
a. independence
b. interdependence
c. niche
d. environment

21. As a population reaches its carrying capacity, there may be an increase in competition for
a. food.
b. shelter.
c. mates.
d. All of the above 
factor?

22. Which of the following is classified as a density-independent regulatory
a. food
b. water
c. severe weather
d. number of nesting sites

23. Identify which population might be least likely to be devastated by a new disease outbreak and why?

a. a small population made up of the offspring of healthy, related parents; disease will likely isolate one trait in population so healthy parents will help avoid disease

b. a large genetically diverse population; disease will likely isolate one trait in population so a large genetically diverse population will be likely be able to withstand disease

c. a small, genetically uniform population; disease will likely isolate one trait in population so a small genetically uniform population will be likely be able to withstand disease without "extra" organisms of a large population

d. a large, genetically uniform population; disease will likely isolate one trait in population so a small genetically uniform population will be likely be able to withstand disease with the "extra" organisms of a large population

24. The diagrams below show different kinds of interactions between species.

The ant keeps predators away from the acacia tree.

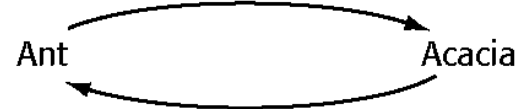

The acacia provides shelter and food for the ant.

1

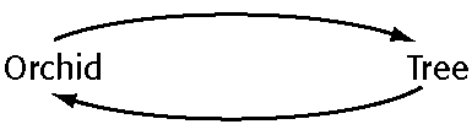

The tree provides nutrients and a sunlit location for the orchid living on it.

3
The cow eats grass.

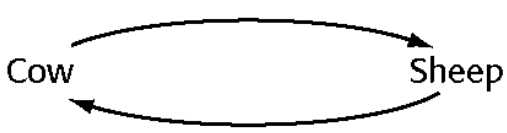

The sheep eats the same grass.

2

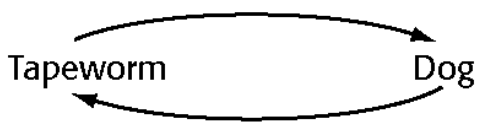

The dog provides nutrients and shelter for the tapeworm living in its intestines.

4

Refer to the illustration above. The relationship shown in diagram 4 is classified as

a. commensalism.

b. competition.

c. mutualism.

d. parasitism. 
25. Refer to the illustration above. The relationship shown in diagram 2 is classified as
a. commensalism.
b. competition.
c. mutualism.
d. parasitism.

26. Refer to the illustration above. The relationship shown in diagram 1 is classified as
a. commensalism.
b. competition.
c. mutualism.
d. parasitism. classified as

27. Refer to the illustration above. The relationship shown in diagram 3 is
a. commensalism.
b. competition.
c. mutualism.
d. parasitism.

28. Describe the characteristics of a parasite.
a. parasites coevolve with their hosts.
b. parasites are usually smaller than their hosts.
c. parasites rarely kill their hosts.
d. All of the above

29. A tick feeding on a human is known as an example of
a. parasitism.
b. mutualism.
c. competition.
d. commensalism.

30. Describe the characteristics that enable plants to protect themselves from herbivores:
a. plants grow thorns and prickles.
b. plants maintain sticky hairs and tough leaves.
c. plants produce chemical defenses.
d. All of the above 
31. The relationship between flowering plants and the bees that pollinate them is an example of
a. commensalism.
b. competition.
c. mutualism.
d. parasitism.

32. Cattle egrets are birds that mostly feed on insects that have been disturbed, and put up into the air, by grazing cattle. The cattle are neither helped nor harmed by the presence of the egrets. Predict what type of relationship a scientist would describe this interaction between a cattle egret and cattle.
a. commensalism.
b. competition.
c. mutualism.
d. parasitism.

33.

\begin{tabular}{|l|l|}
\hline 1 & Both organisms benefit from the activity of each other. \\
\hline 2 & $\begin{array}{l}\text { One organism benefits, and the other organism neither } \\
\text { benefits nor suffers harm. }\end{array}$ \\
\hline 3 & $\begin{array}{l}\text { One organism obtains its nutrients from another, and } \\
\text { the other organism may weaken due to deprivation. }\end{array}$ \\
\hline
\end{tabular}

Refer to the chart above. The table represents three types of
a. competition.
b. rhythmic patterns.
c. symbiosis.
d. secondary succession.

34. A population of organisms will grow when its exceeds its death rate.
a. recovery rate
b. birth rate
c. life expectancy
d. age distribution 
35. is defined as the amount by which a population's size changes in a given amount of time.
a. Birth rate
b. Death rate
c. Growth rate
d. Population dynamics

36. An ecosystem consists of biotic and factors.
a. living
b. abiotic
c. once-living
d. habitat

37. The population size that can be sustained by an environment is called the of the environment.
a. growth rate
b. sustainability
c. population maximum
d. carrying capacity

38. The main reason Earth's human population has increased over the past 350 years is because of a decrease in the
a. birth rate due to increased education and changes in lifestyle.
b. death rate due to increased health care and improvements in living conditions.
c. carrying capacity due to improved living conditions and more efficient use of resources.
d. growth rate due to increased health care and improvements in living conditions.

39. Predict how humans might affect the carbon cycle in the future

a. by continuing to burn fossil fuels as the main fuel source.

b. transitioning to renewable fuels such as hydrogen, wind, and/or solar power.

c. clearing diverse forests that absorb carbon dioxide in order to plant crops (uniform population) to increase food production.

d. All of the above

40. The extinction of species is described as
a. a problem limited to the tropics.
b. a problem that has been accelerated by the activities of people.
c. a problem only where topsoil and groundwater are limited.
d. something that will not be a problem in the coming century. 
41. Ecosystem disruption

a. threatens the existence of thousands of species.

b. increases biodiversity.

c. protects natural habitats.

d. has no effect on biodiversity.

42. The heat-trapping effect of some gases in the atmosphere can be compared to

a. the way snow melts on a sunny day.

b. the way glass traps heat inside a greenhouse.

c. the way water condenses on a glass of ice.

d. the way a teakettle holds water on a stove. because

43. Scientists strongly suspect that temperatures are increasing on Earth
a. decomposers essential to recycling matter are being destroyed.
b. too much oxygen is being given off by plants.
c. increasing carbon dioxide in the atmosphere is trapping more heat.
d. Earth is tilting further toward the sun in the summer.

44. How can human populations live in a sustainable way?

a. by slowing or reversing human population growth

b. by developing new technologies

c. by reducing consumption of natural resources

d. All of the above

45. Evidence suggests that the atmospheric levels of have increased significantly in the last two hundred years and may result in a significant warming of Earth's atmosphere.
a. oxygen
b. nitrogen
c. carbon dioxide
d. water vapor

46. Sustainability is described as:

a. the study of diversity in ecology.

b. the ability to fulfill your own personal needs, without regards to the overall human population and its future.

c. giving up all material belongings.

d. the ability to fulfill human needs in a way that allows the human population to survive indefinitely. 
Essay

Write scientifically: detailed, yet concise. Each essay is worth 5 points.

47. Many environmental problems require international cooperation between governments. However, individuals can also have an impact on the environment. Identify four things that you or your classmates could do, and explain how they could help solve environmental problems.

48. The Upper Peninsula is part of the Laurentian Mixed Forest terrestrial ecosystem. We are also part of the Temperate Forest terrestrial ecosystem. We are surrounded by freshwater river and lake aquatic ecosystems as well.

Identify an abiotic factor and biotic factor that play a role in our ecosystem and explain the influence that each has. Choose an abiotic and biotic factor for both our terrestrial ecosystem and for our aquatic ecosystems (four total factors).

49. Organisms interact in ecology. The types of ecological relationships between organisms include competition, parasitism, symbiosis, and predator/prey. We have looked at the effects on each "player" in the relationship, as well as real-world examples of each type of relationship.

Choose one type of ecological relationship and synthesize two imaginary organisms that are affected by it. Your answer should include an explanation of the ecological relationship and how it affects each of the "players." You should also include a drawing of your organisms - the drawing should label and describe the traits that affect the ecological relationship. 


\section{Ecology PrePostTest}

Answer Section

\section{MULTIPLE CHOICE}

1. C

2. D

3. $\mathrm{A}$

4. B

5. D

6. C

7. C

8. A

9. B

10. C

11. D

12. A

13. B

14. C

15. D

16. B

17. D

18. C

19. D

20. B

21. D

22. C

23. B

24. D

25. B

26. C

27. A

28. D

29. A

30. D

31. C

32. A

33. C

34. B

35. C

36. B

37. D

38. B

39. D

40. B 
41. A

42. B

43. C

44. D

45. C

46. D

ESSAY

47-49. Graded with self-developed rubric. 


\section{Appendix B. Ecosystems Unit Objectives and Vocabulary}

Science 6

Mr. Ziegler

Unit 5: Ecosystems

\section{"Big Ideas"}

1. All life forms, including humans, are part of a global food chain in which food is supplied by plants, which need light to produce food.

2. Ecosystems continually change with time as environmental factors and populations of organisms change.

\section{Objectives}

1. Identify the biotic and abiotic factors in ecosystems.

2. Define and identify producers, consumers, and decomposers in ecosystems that could be found in Michigan.

3. Describe the characteristics of populations and communities within Michigan ecosystems.

4. Identify characteristics of parasitic relationships.

5. Understand how human activities change environmental conditions and positively and negatively impact ecosystems.

\section{Vocabulary}

Critical Vocabulary
ecosystem
biotic components
abiotic components
population
community
producers
consumers
decomposers
bacteria
fungus
parasite
predator
prey
symbiosis
competition
pollution

resource depletion
species extinction
Useful Vocabulary
niche
climate change
environmental impact
balance in ecosystems
source of energy
habitat
food web
forests
wetlands
ponds
lakes
tropical rainforest
tundra

desert coral reef dunes prairies 
This page deliberately blank 


\section{Appendix C. Producers, Consumers, and Decomposers Subunit Resources}

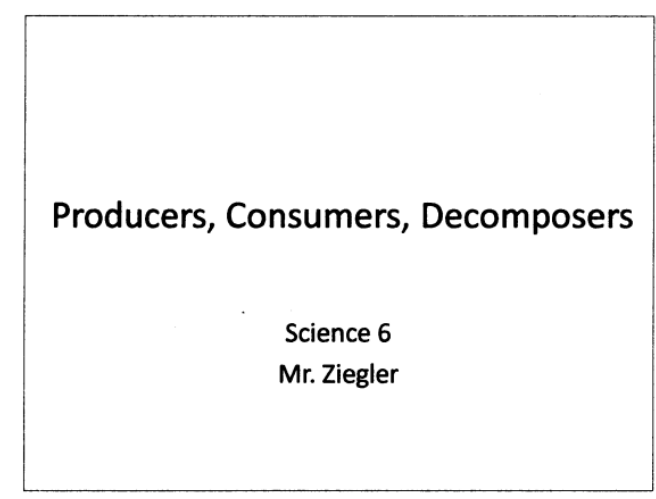

\begin{tabular}{|l|}
\multicolumn{1}{|c|}{ Energy Transfer } \\
- Producers (Autotrophs) \\
- Consumers (Heterotrophs) \\
- Herbivores \\
- eat producers \\
- Carnivores \\
- eat consumers \\
- Omnivores \\
- eat producers and consumers \\
Decomposers \\
- Detritivores \\
$\cdot$ feed on detritus (waste) \\
- Decomposers \\
$\cdot$ recyclers - break down organic material \\
\end{tabular}

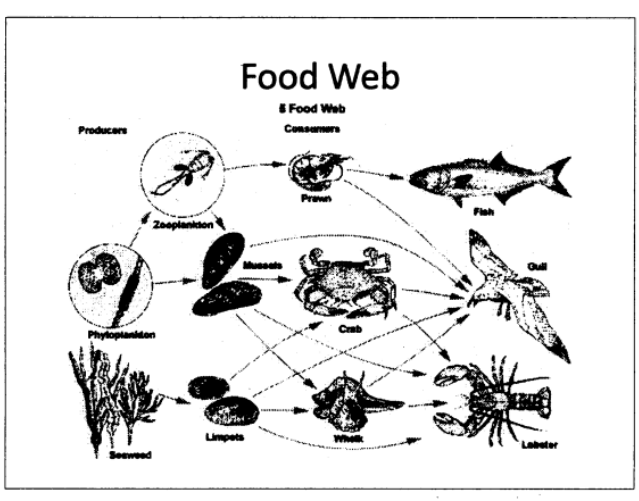

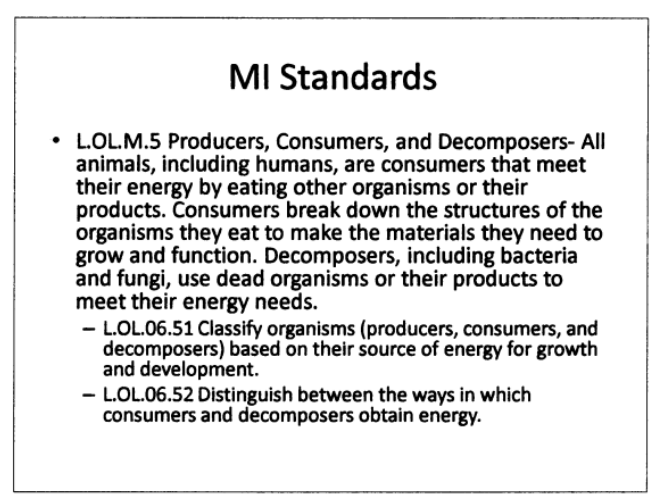
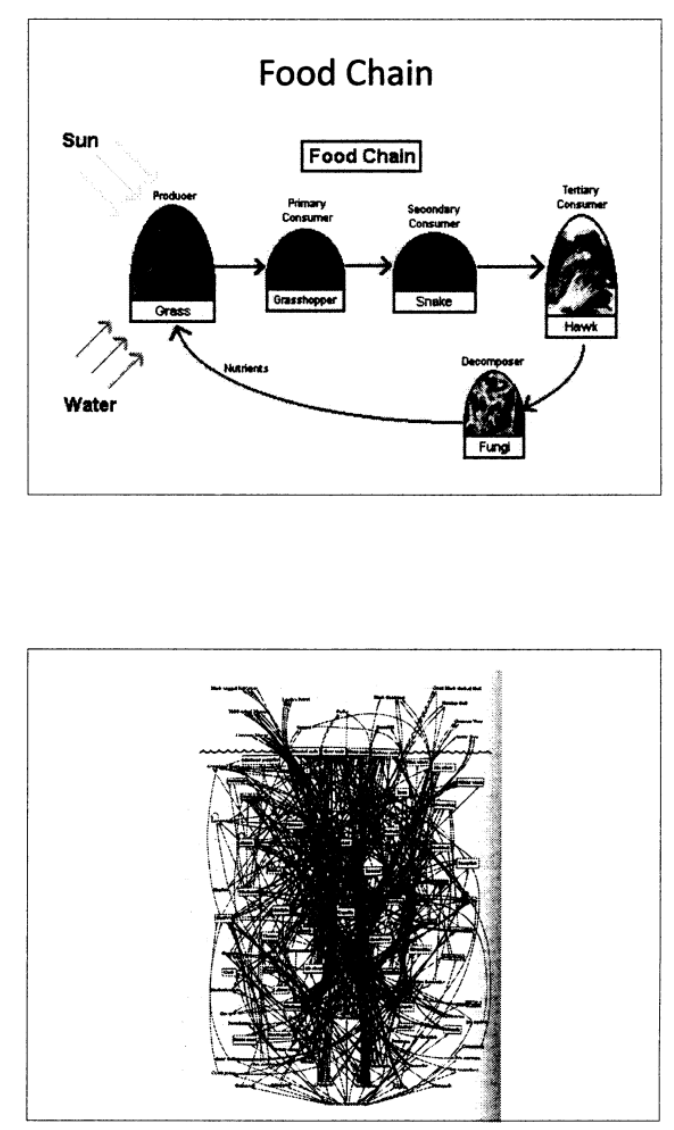

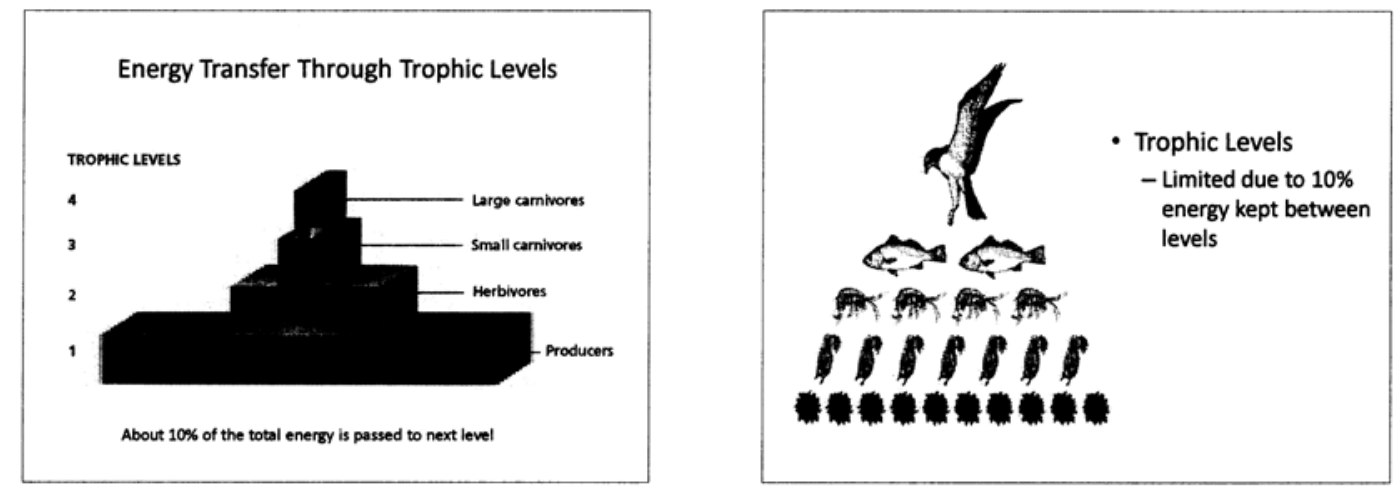

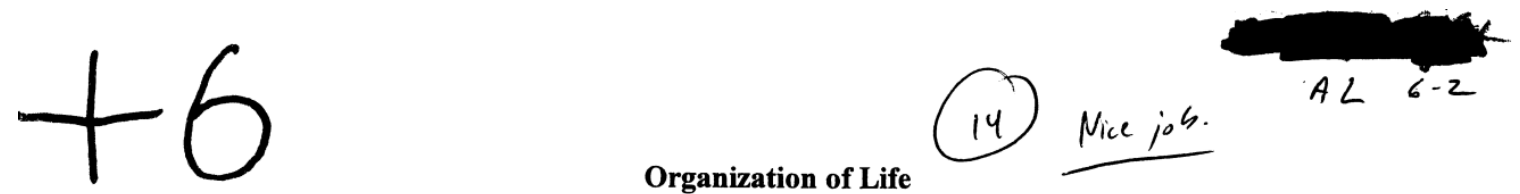

Organization of Life

Science 6

Quiz

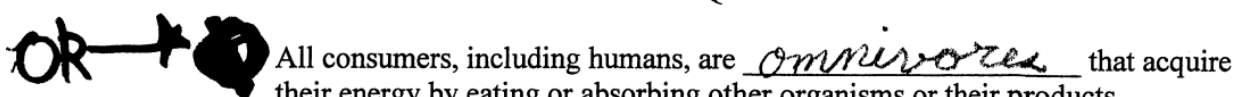
their energy by eating or absorbing other organisms or their products.

2. Decoragereere, including bacteria or fungi, use dead organisms or their products $f 0$ meet their energy needs.

3. Organisms that acquire their energy from the sun (photosynthesis) or chemicals (chemosynthesis) are known as provered.

4. List an example of a consumer. Human

5. List an example of a decomposer. feungí

6. List an example of a producer. Tree

7. Both consumers and decomposers acquire their energy by obtaining (eating/absorbing) other organisms. What is the main difference in how

1 consumers and decompgsers acguire this energy? decompgre a dowhy beak

8. What is the definition of life science? the study of beit, comsumere finex:

9. What areathe steps in order, of the Scientific Method?

9. What areahe steps, in order, of the Scientific Method?

10. Create a food chain, including the followng:
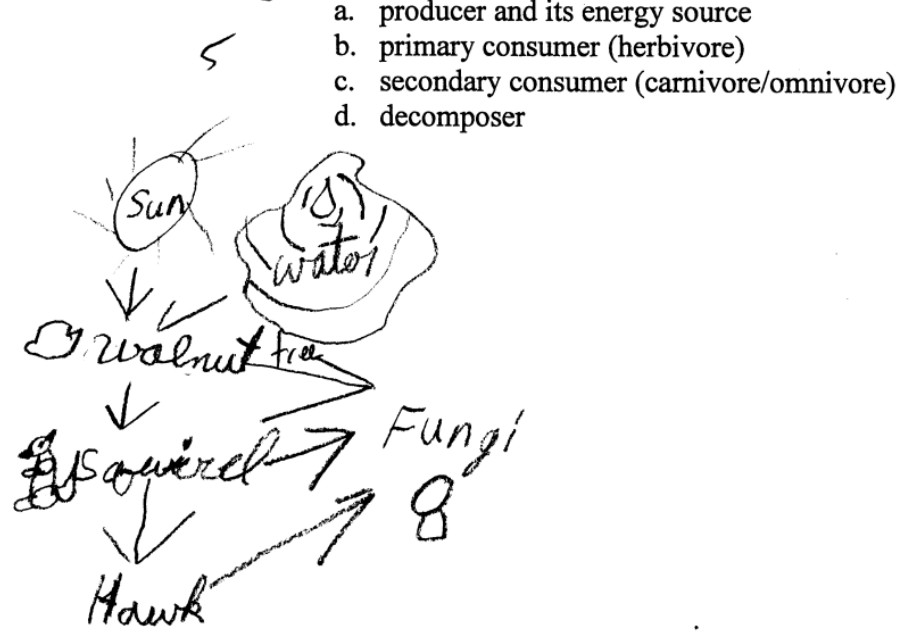

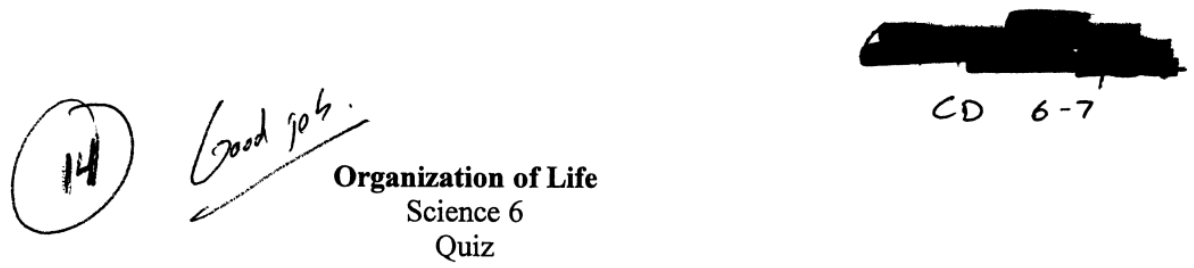

1. All consumers, including humans, are carnivores that acquire their energy by eating or absorbing other organisms or their products.

2. Lecomposers, including bacteria or fungi, use dead organisms or their products to meet their energy needs.

3. Organisms that acquire their energy from the sun (photosynthesis) or chemicals (chemosynthesis) are known as producers.

4. List an example of a consumer.

5. List an example of a decomposer.

Fung,

6. Listan example of a producer.

7. Both consumers and decomposers acquire their energy by obtaining (eating/absorbing) other organisms. What is the main difference in how Consumers eat their food, Decomposers slowly adsorb theirs,

8. What is the definition of life science? The study of organisms and how they interact, 9. What are the steps, in order, of the Scientific Method?

10. Create a food chain, including the following:

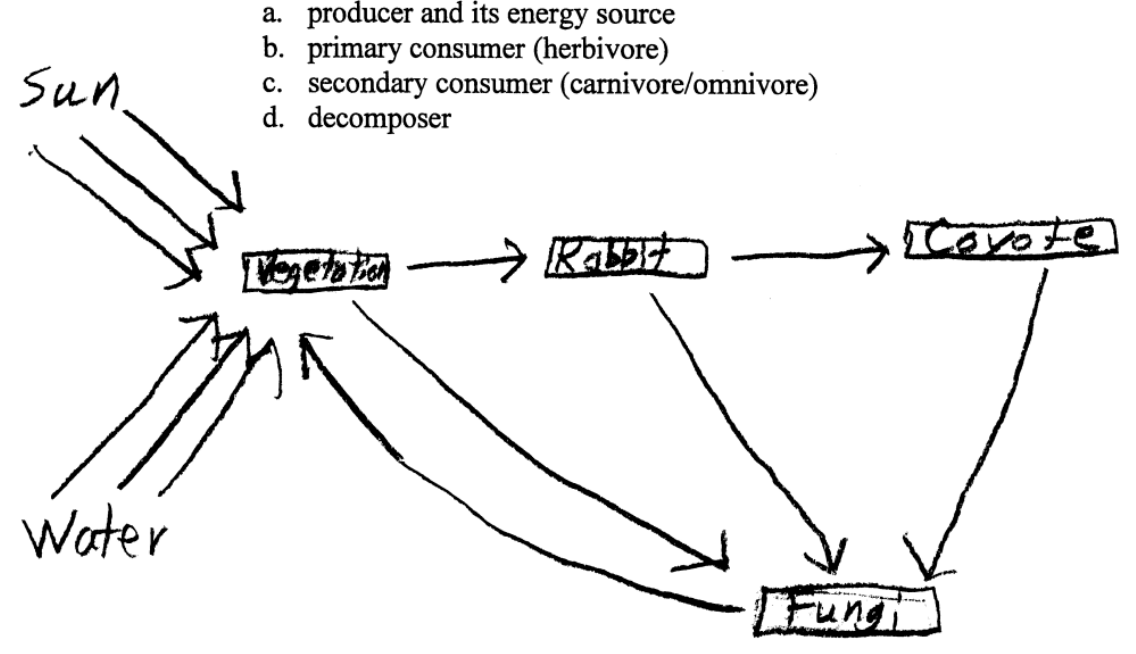




\section{Appendix D. Interactions of Organisms Subunit Resources}

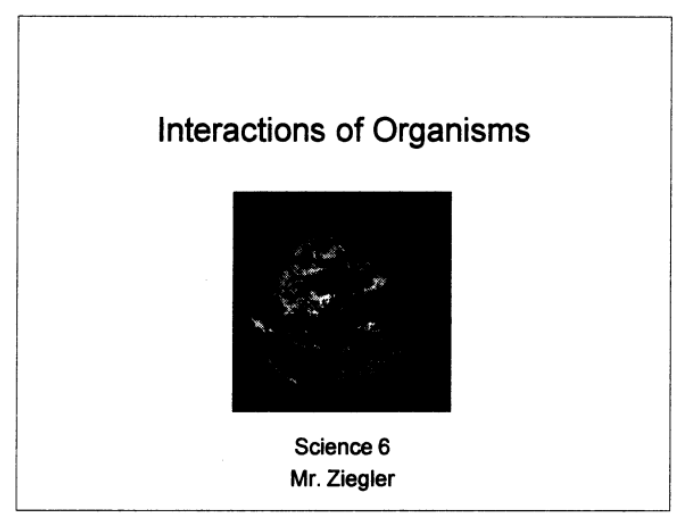

- Ecology: Study of Interactions between Organisms and the Living (Biotic) and Non-Living (Abiotic) Components of the Environment

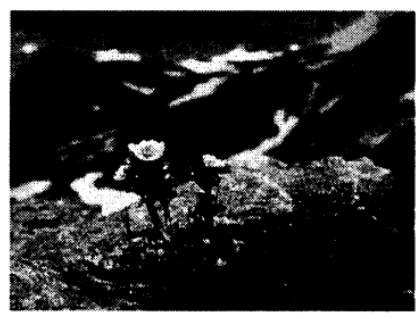

\section{Population}

- Group of organisms that belong to the same species and live in a particular place at the same time

- Affected by size, density, and dispersion (pattern)

\section{Standards}

- L.EC.M.1 Interactions of OrganismsOrganisms of one species form a population. Populations of different organisms interact and form communities. Living communities and nonliving factors that interact with them form ecosystems.

- L.EC.06.11 List examples of populations, communities, and ecosystems including the Great Lakes region.
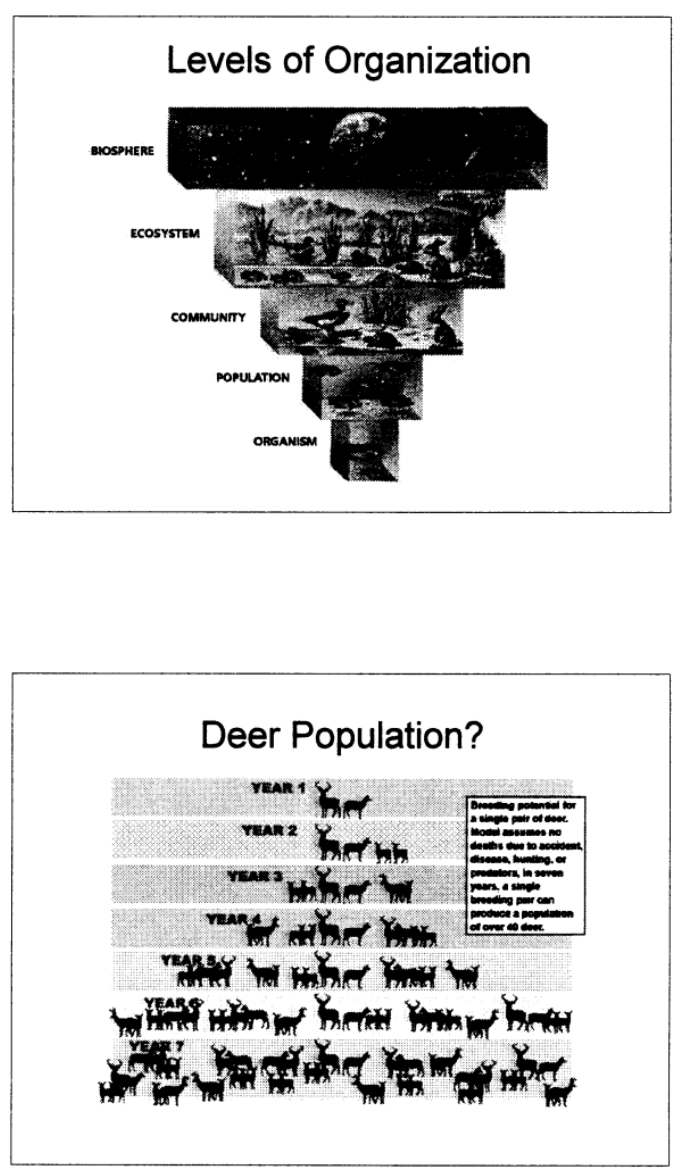

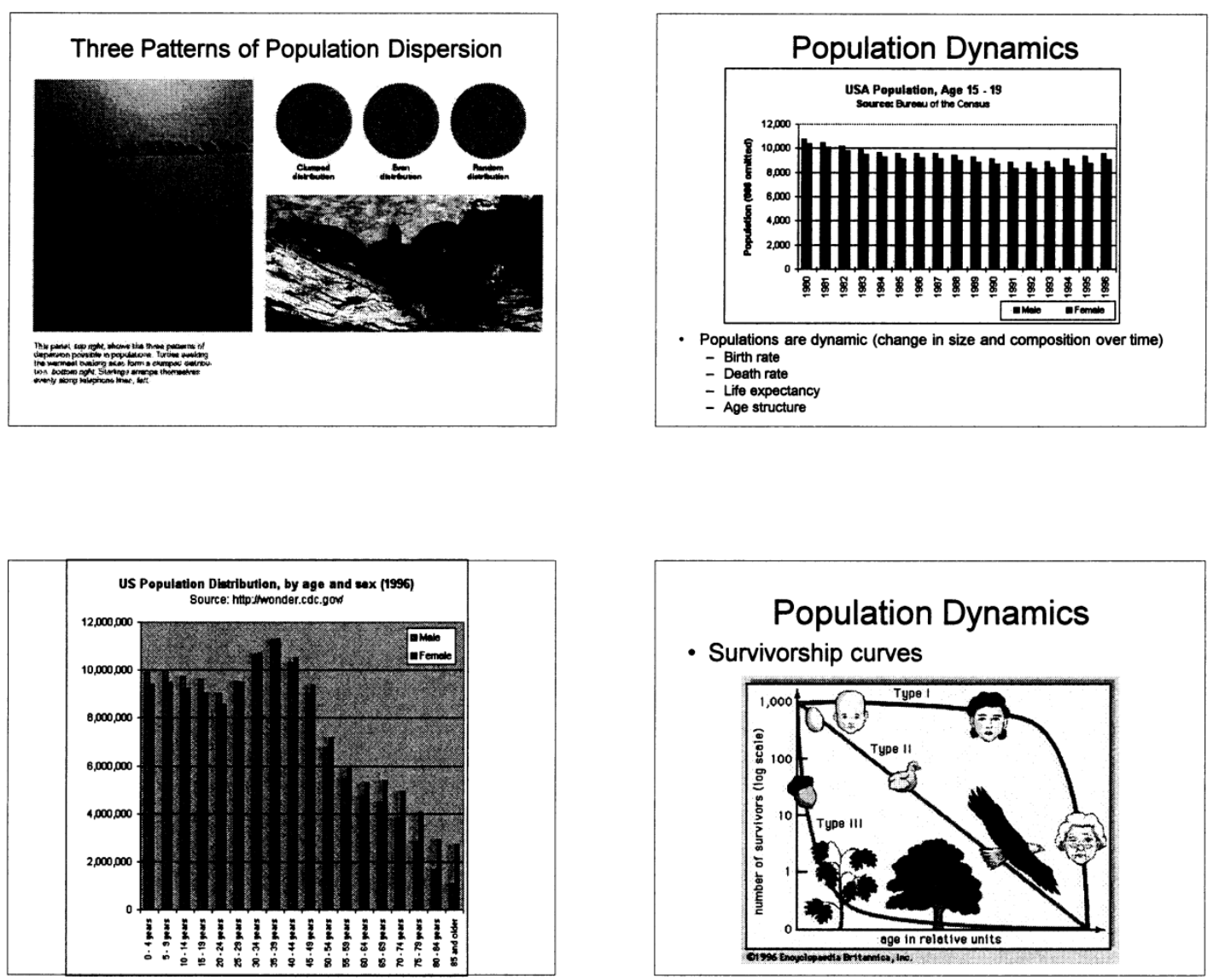

\section{Population Growth Rate}

- Populations change due to:

-Birth

- Death

- Immigration

- Emigration

- Growth rate formula

birth rate - death rate $=$ growth rate

(assumes migration is zero)

\section{Exponential vs. Logistic Growth}

(a) Exponential (unrestricted) growth

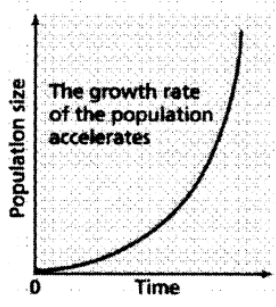

(b)Logistic (restricted) growth

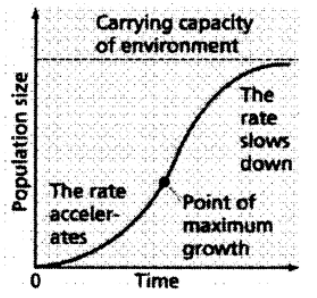




\section{Population Regulation}

- Density-dependent

- Resource limitations (food, habitat)

- Disease

- Density-independent

- Natural disasters (flood, fires)

-Weather

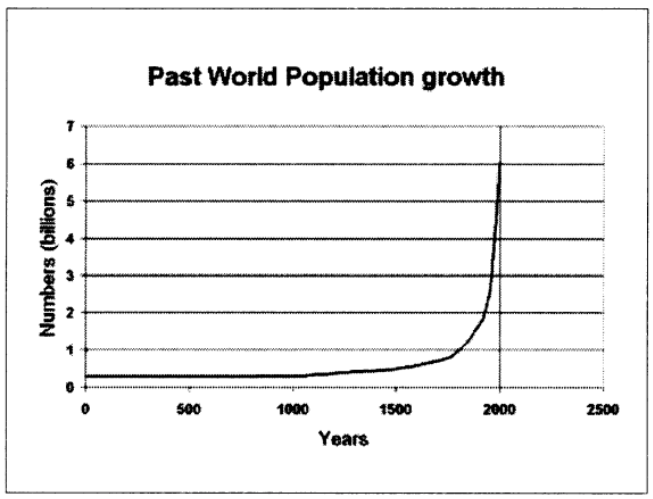

\section{Community}

- Group of various species that live in the same habitat and interact with each other

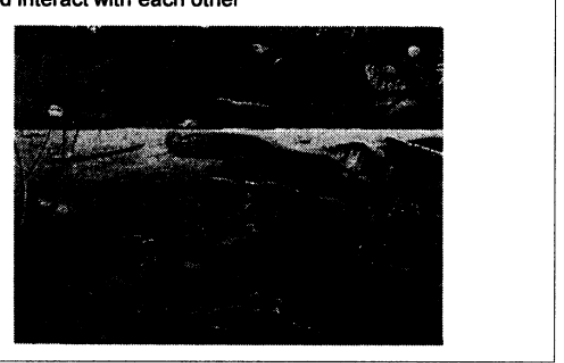

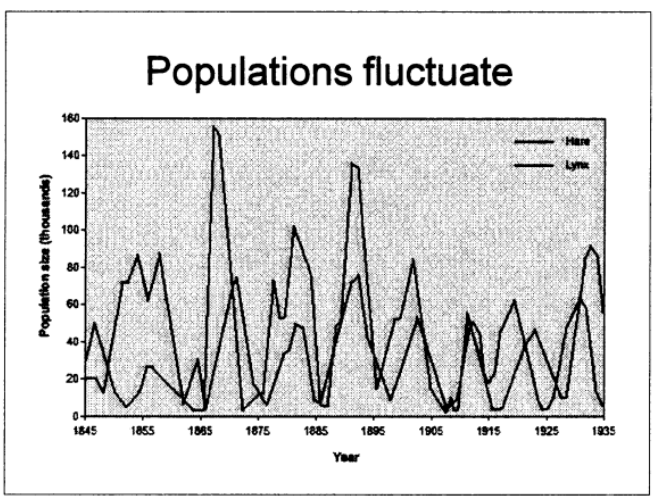

\section{Human Population Growth}

- http://www.pbs.org/wgbh/nova/worldbalance/

\section{Species Interactions in a Community}

- Predation

- Competition

- Parasitism

- Mutualism

- Commensalism 


\section{Ecosystem}

- community of organisms (biotic) and abiotic environment

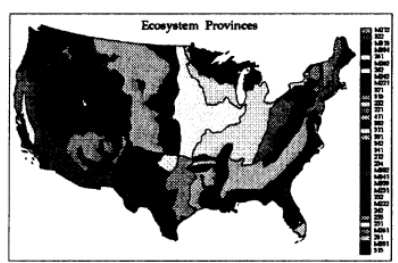

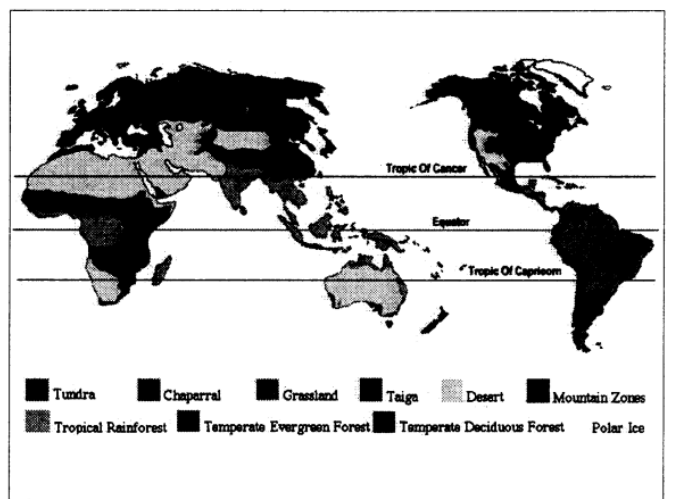

\section{Temperate Forests}

- Coniferous

- Evergreen, cone (seeds)

- Deciduous

- Trees shed leaves

- Definite seasons

- Variable precipitation

- Soil: moderate

depth and

nutrients

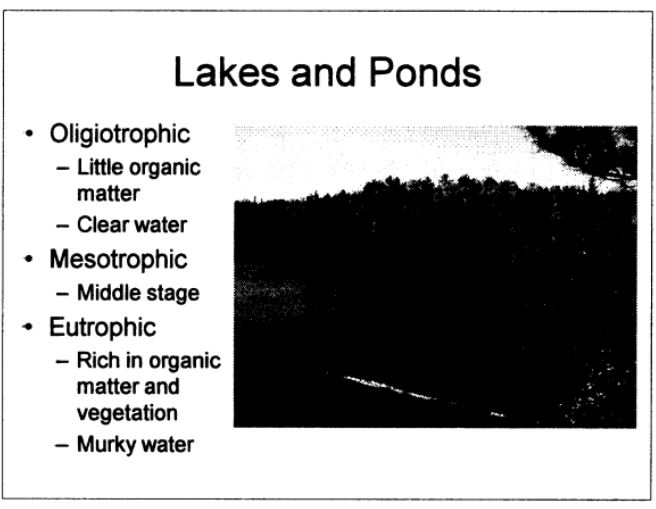

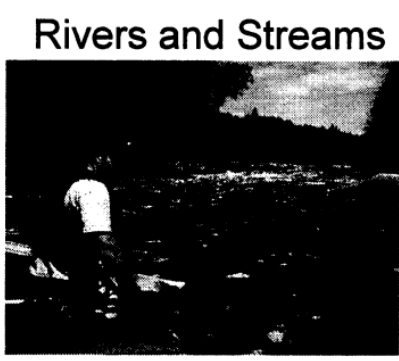

- Stages in a river's development as well - Young: high gradient

- Old: lower gradient, more meanders 

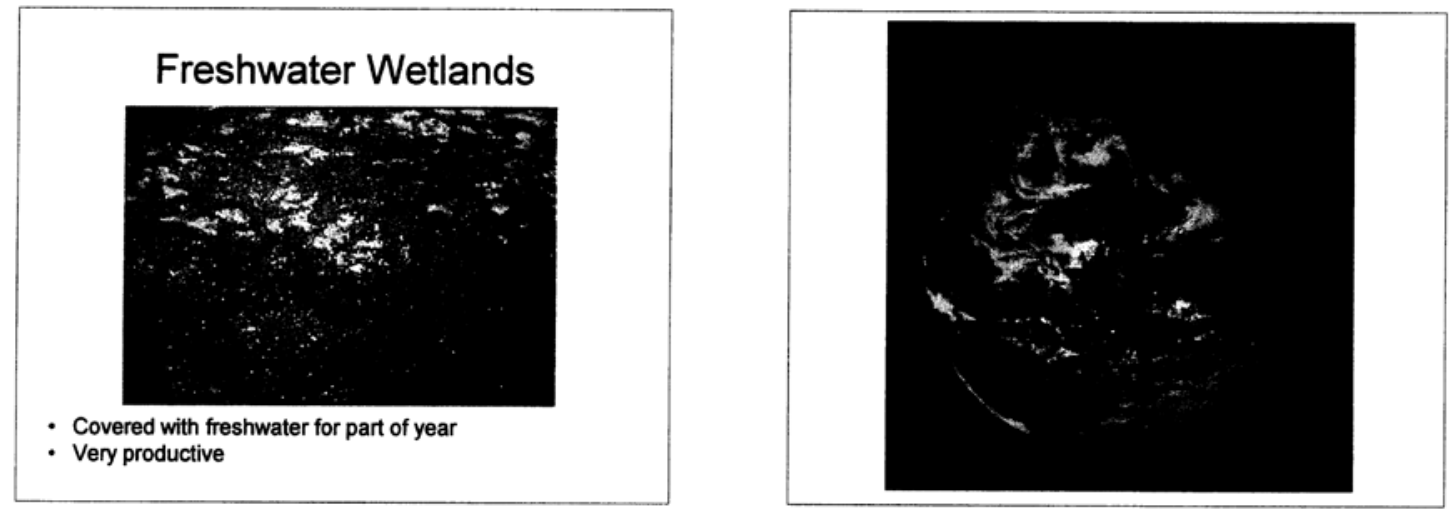


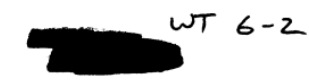

\author{
Interactions of Organisms \\ Ecosystems, Communities, and Populations in the Upper Peninsula of Michigan \\ Research Summary
}

Notes:

A population is a group of the same species. Populations of different organisms interact and form communities. Living communities and nonliving factors that interact with them form ecosystems.

Assignment:

Please choose a population of organisms that lives in the U.P. and describe it. Work your way up the organization scale to the representative community that your population is a part of and describe this community. Finally, describe the representative ecosystem that includes your community and population. Your summary should include a paragraph description for population, community, and ecosystem. You should also include representative pictures.

\begin{tabular}{|c|c|c|c|c|}
\hline \multicolumn{5}{|c|}{ Research Rubric } \\
\hline & 3 & 2 & 1 & 0 \\
\hline Population & $\begin{array}{c}\text { Accurate } \\
\text { description of } \\
\text { population, with } \\
\text { several supporting } \\
\text { details. }\end{array}$ & $\begin{array}{c}\text { Accurate } \\
\text { description of } \\
\text { population, with } \\
\text { few supporting } \\
\text { details. }\end{array}$ & $\begin{array}{c}\text { Accurate } \\
\text { description of } \\
\text { population, but no } \\
\text { supporting details. }\end{array}$ & $\begin{array}{l}\text { Inaccurate } \\
\text { description of } \\
\text { population. }\end{array}$ \\
\hline Community & $\begin{array}{c}\text { Accurate } \\
\text { description of } \\
\text { community, with } \\
\text { several supporting } \\
\text { details. }\end{array}$ & $\begin{array}{c}\text { Accurate } \\
\text { description of } \\
\text { community, with } \\
\text { few supporting } \\
\text { details. }\end{array}$ & $\begin{array}{c}\text { Accurate } \\
\text { description of } \\
\text { community, but no } \\
\text { supporting details. }\end{array}$ & $\begin{array}{l}\text { Inaccurate } \\
\text { description of } \\
\text { community. }\end{array}$ \\
\hline Ecosystem & $\begin{array}{c}\text { Accurate } \\
\text { description of } \\
\text { ecosystem, with } \\
\text { several supporting } \\
\text { details. }\end{array}$ & $\begin{array}{c}\text { Accurate } \\
\text { description of } \\
\text { ecosystem, with } \\
\text { few supporting } \\
\text { details. }\end{array}$ & $\begin{array}{c}\text { Accurate } \\
\text { description of } \\
\text { ecosystem, but no } \\
\text { supporting details. }\end{array}$ & $\begin{array}{l}\text { Inaccurate } \\
\text { description of } \\
\text { ecosystem. }\end{array}$ \\
\hline Pictures & $\begin{array}{c}\text { Representative } \\
\text { pictures/drawings } \\
\text { for population, } \\
\text { community, and } \\
\text { ecosystem are } \\
\text { included. }\end{array}$ & $\begin{array}{l}\text { Representative } \\
\text { pictures/drawings } \\
\text { are included. }\end{array}$ & $\begin{array}{l}\text { Pictures/drawings } \\
\text { are included, but } \\
\text { are not } \\
\text { representative. }\end{array}$ & $\begin{array}{l}\text { Pictures/drawings } \\
\text { are not included. }\end{array}$ \\
\hline
\end{tabular}

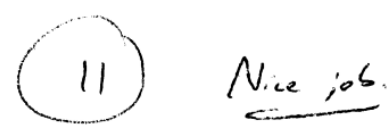




\section{Rusty Population}

\section{Crayfish Information}

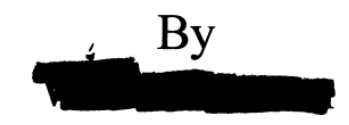

If Rusty Crayfish start invading Lakes/Streams the vegetation, fish populations would go down. These lobster like creatures can wipe out a whole population in a month time! The reason why these are so bad is because there is nothing to eat them (except humans) and eat all of the producers in lakes/streams.

Their habitat is anything that huge and has water. Example, in Swan Lake if you go forty feet off the shore there is millions upon thousands of the Crayfish. Also, the Rusty Crayfish kill native species. The Rusty Crayfish feeds on walleye eggs and attacks all kinds of fish to get the eggs. Also they feed on maggots, mayflies, stoneflies, and midges. The Rusty Crayfish in the end KILLS regular fish by the thousands.

The Crayfish has little to no enemies; that's why they live to FOUR to THREE years! "It takes one female to make a whole devastation of crayfish.' Rusty Crayfish just live in lakes/streams in general. Their original home is Kentucky and Ohio and was used as bait in MI lake/stream waters.

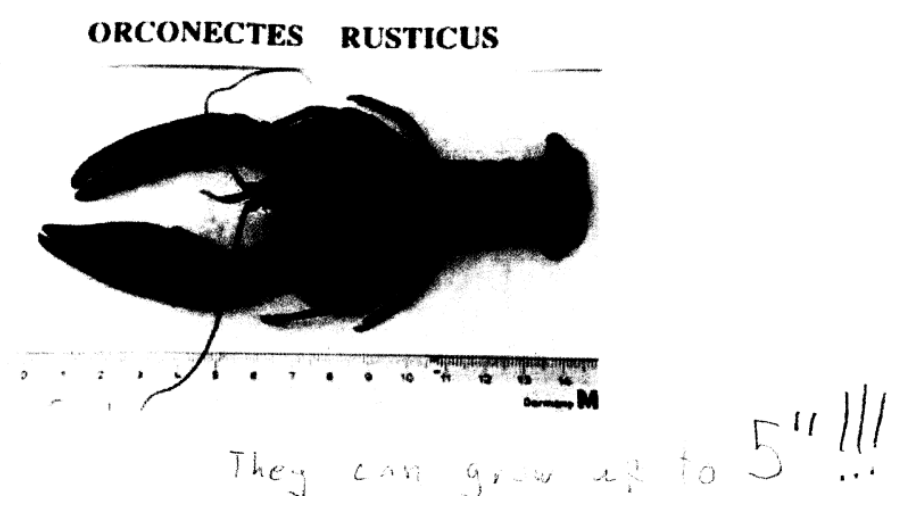




\section{Interactions of Organisms \\ Ecosystems, Communities, and Populations in the Upper Peninsula of Michigan Research Summary}

Notes:

A population is a group of the same species. Populations of different organisms interact and form communities. Living communities and nonliving factors that interact with them form ecosystems.

Assignment:

Please choose a population of organisms that lives in the U.P. and describe it. Work your way up the organization scale to the representative community that your population is a part of and describe this community. Finally, describe the representative ecosystem that includes your community and population. Your summary should include a paragraph description for population, community, and ecosystem. You should also include representative pictures.

\begin{tabular}{|c|c|c|c|c|}
\hline \multicolumn{5}{|c|}{ Research Rubric } \\
\hline & 3 & 2 & 1 & 0 \\
\hline Population & $\begin{array}{c}\text { Accurate } \\
\text { description of } \\
\text { population, with } \\
\text { several supporting } \\
\text { details. }\end{array}$ & $\begin{array}{c}\text { Accurate } \\
\text { description of } \\
\text { population, with } \\
\text { few supporting } \\
\text { details. }\end{array}$ & $\begin{array}{c}\text { Accurate } \\
\text { description of } \\
\text { population, but no } \\
\text { supporting details. }\end{array}$ & $\begin{array}{l}\text { Inaccurate } \\
\text { description of } \\
\text { population. }\end{array}$ \\
\hline Community & $\begin{array}{c}\text { Accurate } \\
\text { description of } \\
\text { community, with } \\
\text { several supporting/ } \\
\text { details. }\end{array}$ & $\begin{array}{c}\text { Accurate } \\
\text { description of } \\
\text { community, with } \\
\text { few supporting } \\
\text { details. }\end{array}$ & $\begin{array}{c}\text { Accurate } \\
\text { description of } \\
\text { community, but no } \\
\text { supporting details. }\end{array}$ & $\begin{array}{l}\text { Inaccurate } \\
\text { description of } \\
\text { community. }\end{array}$ \\
\hline Ecosystem & $\begin{array}{c}\text { Accurate } \\
\text { description of } \\
\text { ecosystem, with } \\
\text { several supporting } \\
\text { details. }\end{array}$ & $\begin{array}{c}\text { Accurate } \\
\text { description of } \\
\text { ecosystem, with } \\
\text { few supporting } \\
\text { details. }\end{array}$ & $\begin{array}{c}\text { Accurate } \\
\text { description of } \\
\text { ecosystem, but no } \\
\text { supporting details. }\end{array}$ & $\begin{array}{l}\text { Inaccurate } \\
\text { description of } \\
\text { ecosystem. }\end{array}$ \\
\hline Pictures & $\begin{array}{c}\text { Representative } \\
\text { pictures/drawings } \\
\text { for population, } \\
\text { community, and } \\
\text { ecosystem are } \\
\text { included. }\end{array}$ & $\begin{array}{c}\text { Representative } \\
\text { pictures/drawings } \\
\text { are included. }\end{array}$ & $\begin{array}{l}\text { Pictures/drawings } \\
\text { are included, but } \\
\text { are not } \\
\text { representative. }\end{array}$ & $\begin{array}{l}\text { Pictures/drawings } \\
\text { are not included. }\end{array}$ \\
\hline
\end{tabular}

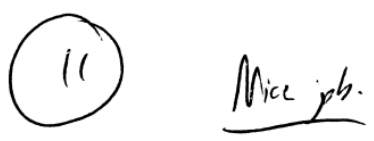




\section{Gray Wolf( Canis lupus)}

By

- In a period of just 20 years, the number of wolves in Michigan has increased from one pair to nearly 580 wolves. For the past 12 years, the wolf population has increased every year,this is a healthy number. They are approaching three times the minimum population that biologists consider to be viable in this state. This has been a conservation success that should make the people of Michigan proud.

Wolves do not have any predator because we are not aloud to kill the gray wolf because they are on the endangered list. Wolves can eat every five to six hours when there is plenty of food or they can live on scraps for two weeks if there is less food.Wolves eat several large animals such as moose, deer, elk, caribou, and musk oxen. Wolves will also eat smaller animals such as beavers, rabbits, hares, voles, fish, muskrats, lemmings, raccoons, shrews, woodchucks, shellfish, ground squirrels, mice, and birds. The wolf is at the top of the food chain and has no natural enemies. Their only threat is humans. Wolves help keep the ecosystem's population in check by preying on the weak animals so there will be food for the stronger individuals.

The wolf lives in a temperate mixed forest,there is a lot of other animals in this area so the gray wolves has lots of food to feast on. The bad thing is when humans come and kill some of the gray wolves food. But humans plant forest and the trees give the gray wolf some place to live and to take there cubs to.

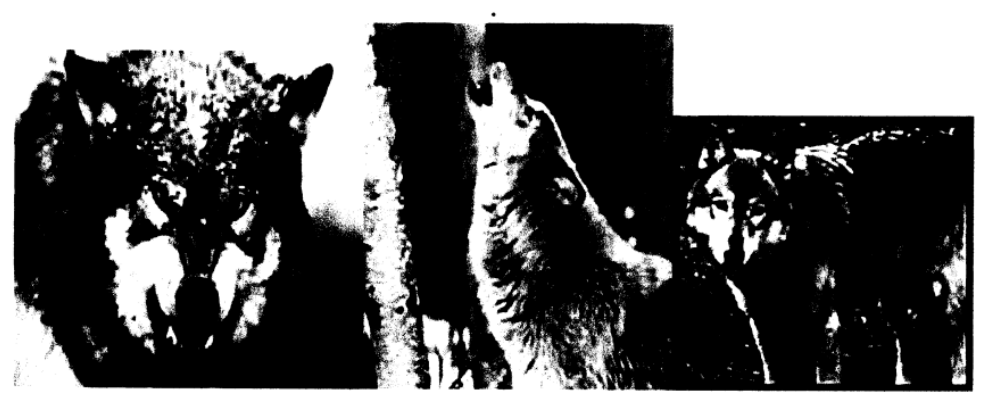




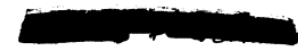

SS PJ 6.2

Science 6

Mr. Ziegler

Unit 5: Ecosystems

Interactions of Organisms

The Value of a U.P. Ecosystem

You will work in groups to create a tri-fold brochure promoting the "value" of an ecosystem in the Upper Peninsula. You may choose one of the following ecosystems:

1 Temperate mixed forest

2. Wetland

3. Lake/Pond

4. River/Stream

You will be evaluated on the following aspects:

1. Populations of animals and plants

2. Human uses

a. Describe both positive and negative uses

3. Sustainability

a. How can we support this ecosystem in a sustainable way?

4. Why the selected ecosystem should be visited (promotional campaign)

a. Both through brochure and presentation

\begin{tabular}{|c|c|c|c|c|}
\hline \multicolumn{5}{|c|}{ Brochure Rubric } \\
\hline & 3 & 2 & 1 & 0 \\
\hline $\begin{array}{c}\text { Populations of } \\
\text { Animals and Plants }\end{array}$ & $\begin{array}{c}5 \text { accurate } \\
\text { populations of } \\
\text { animals and plants } \\
\text { listed. }\end{array}$ & $\begin{array}{c}\text { 3-4 accurate } \\
\text { populations of } \\
\text { animals and plants } \\
\text { listed. }\end{array}$ & $\begin{array}{c}\text { 1-2 accurate } \\
\text { populations of } \\
\text { animals and plants } \\
\text { listed. }\end{array}$ & $\begin{array}{l}\text { Inaccurate listing } \\
\text { of populations of } \\
\text { animals and plants. }\end{array}$ \\
\hline Human Uses & $\begin{array}{c}\text { Accurate and } \\
\text { detailed examples } \\
\text { of both postive } \\
\text { and negative uses. }\end{array}$ & $\begin{array}{c}\text { Accurate examples } \\
\text { of both positive } \\
\text { and negative uses. }\end{array}$ & $\begin{array}{l}\text { Accurate examples } \\
\text { of either positive } \\
\text { or negative (not } \\
\text { both) uses. }\end{array}$ & $\begin{array}{l}\text { Inaccurate } \\
\text { description of } \\
\text { human uses. }\end{array}$ \\
\hline Sustainability & $\begin{array}{c}\text { Accurate and } \\
\text { detailed } \\
\text { description of how } \\
\text { ecosystem can be } \\
\text { supported in a } \\
\text { sustainable way. }\end{array}$ & $\begin{array}{c}\text { Accurate } \\
\text { description of how } \\
\text { ecosystem can be } \\
\text { supported in a } \\
\text { sustainable way. }\end{array}$ & $\begin{array}{l}\text { Description of how } \\
\text { ecosystem can be } \\
\text { supported, but not } \\
\text { in a sustainable } \\
\text { way. }\end{array}$ & $\begin{array}{c}\text { Inaccurate } \\
\text { description of how } \\
\text { ecosystem can be } \\
\text { supported in a } \\
\text { sustainable way. }\end{array}$ \\
\hline Value & $\begin{array}{l}\text { Value of } \\
\text { ecosystem is } \\
\text { promoted through } \\
\text { brochure and } \\
\text { presentation. }\end{array}$ & $\begin{array}{l}\text { Value of } \\
\text { ecosystem is } \\
\text { promoted through } \\
\text { brochure or } \\
\text { presentation (not } \\
\text { both). }\end{array}$ & $\begin{array}{l}\text { Value of ecosystem } \\
\text { is vaguely implied. }\end{array}$ & $\begin{array}{l}\text { Value of ecosystem } \\
\text { is not mentioned } \\
\text { or implied. }\end{array}$ \\
\hline
\end{tabular}

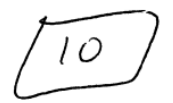



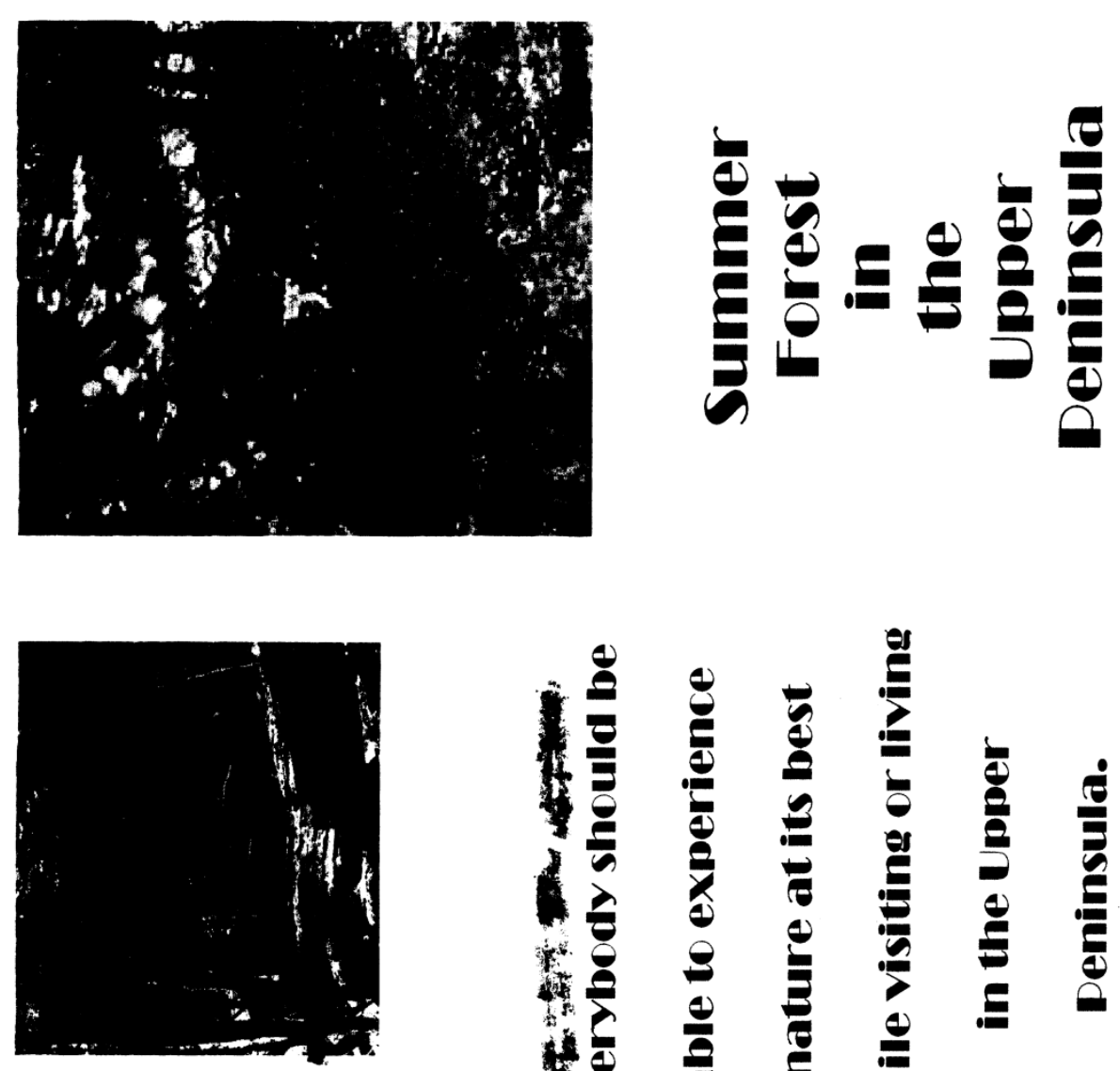

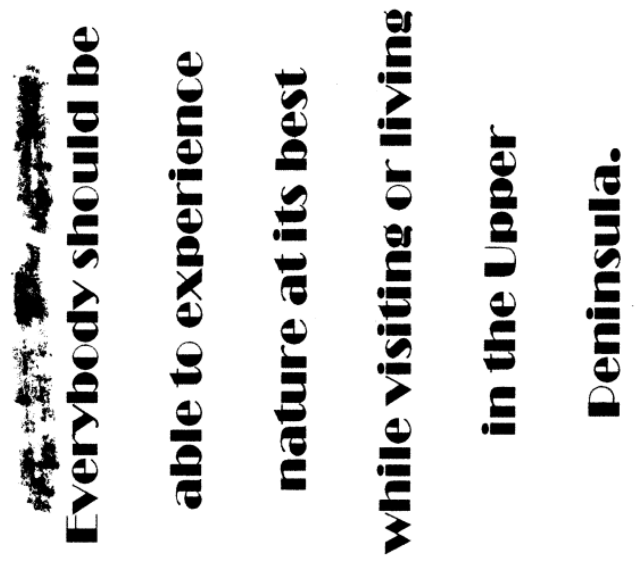

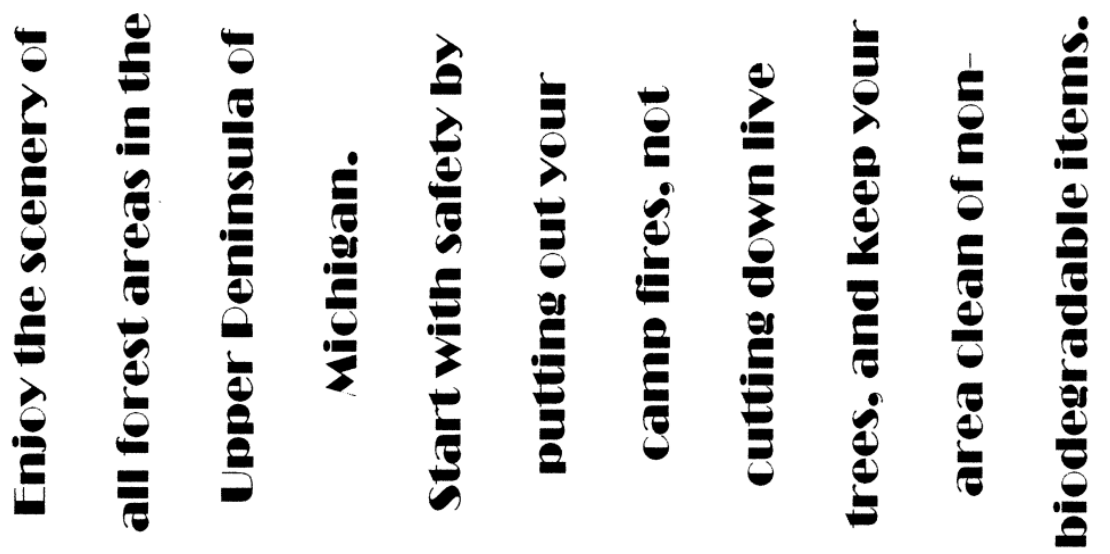



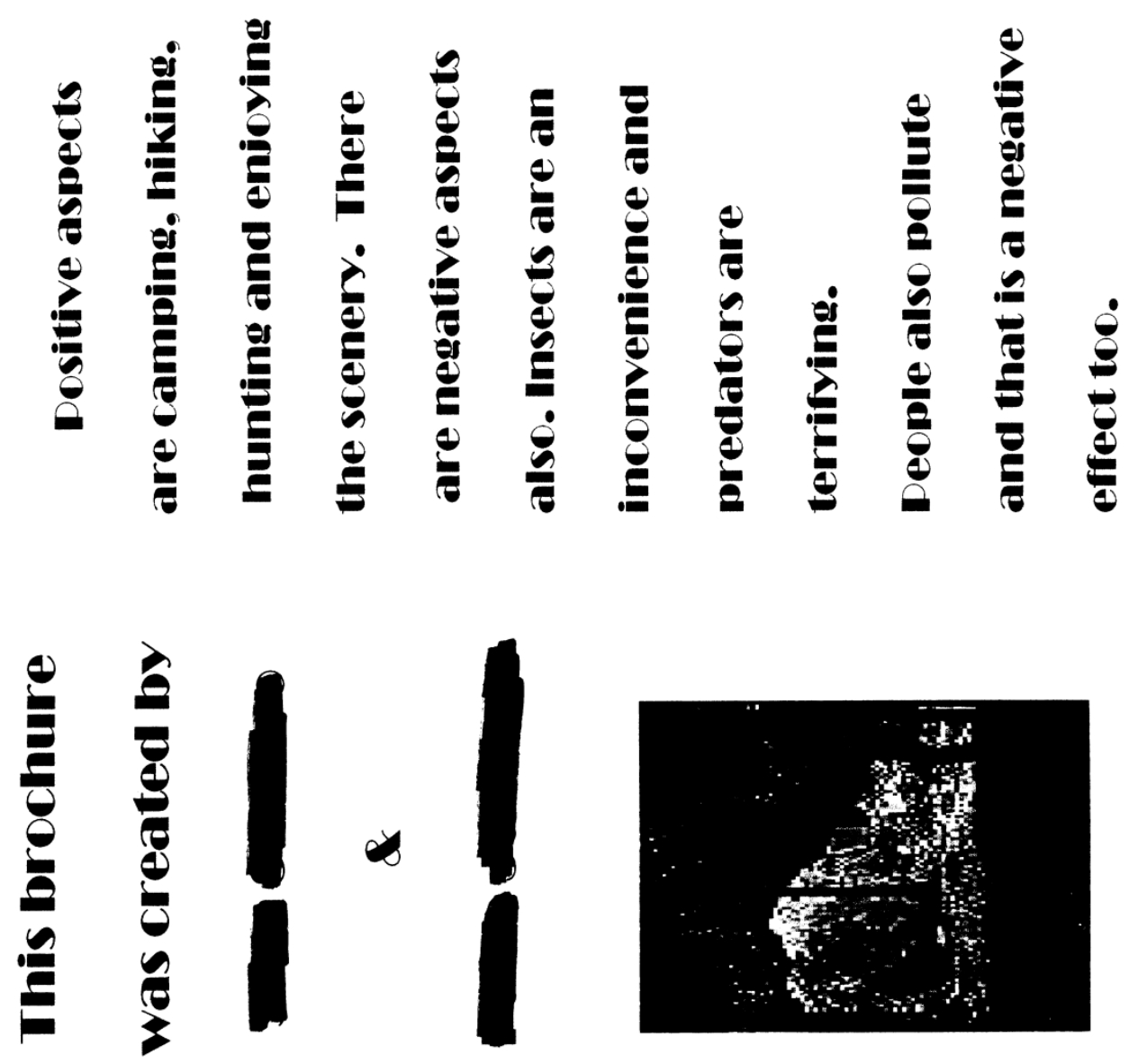

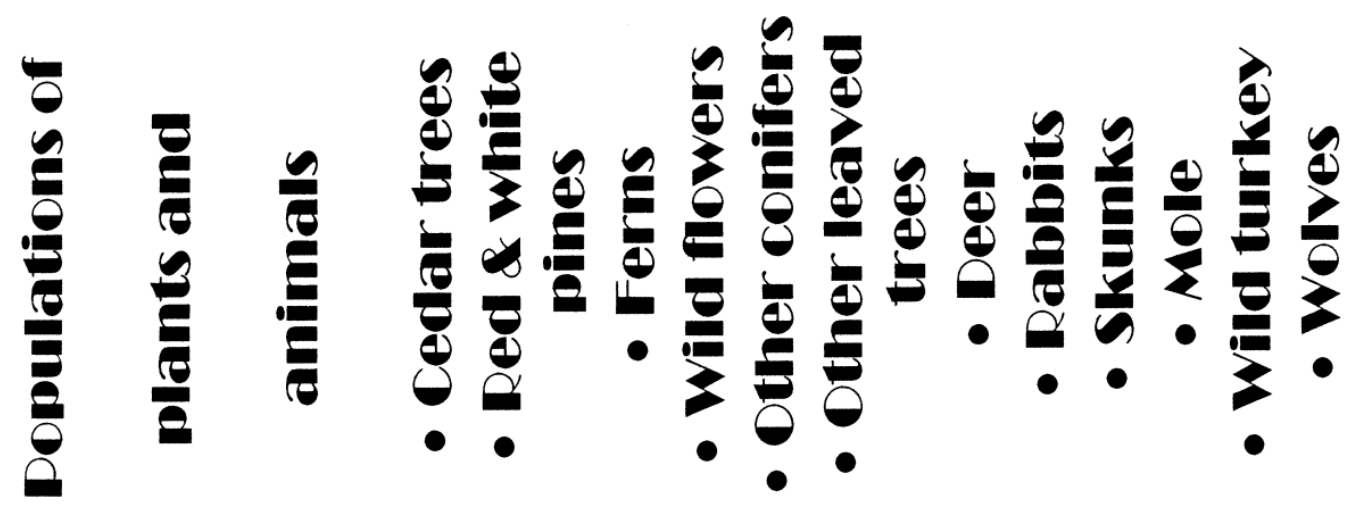




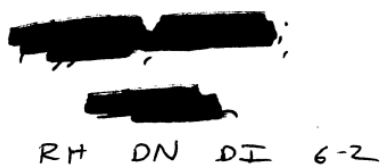

Unit 5: Ecosystems

Interactions of Organisms

The Value of a U.P. Ecosystem

You will work in groups to create a tri-fold brochure promoting the "value" of an ecosystem in the Upper Peninsula. You may choose one of the following ecosystems:

1. Temperate mixed forest

2. Wetland

3. Lake/Pond

4. River/Stream

You will be evaluated on the following aspects:

1. Populations of animals and plants

2. Human uses

a. Describe both positive and negative uses

3. Sustainability

a. How can we support this ecosystem in a sustainable way?

4. Why the selected ecosystem should be visited (promotional campaign)

a. Both through brochure and presentation

\begin{tabular}{|c|c|c|c|c|}
\hline \multicolumn{5}{|c|}{ Brochure Rubric } \\
\hline & 3 & 2 & 1 & 0 \\
\hline $\begin{array}{c}\text { Populations of } \\
\text { Animals and Plants }\end{array}$ & $\begin{array}{c}5 \text { accurate } \\
\text { populations of } \\
\text { animals and plants } \\
\text { listed. }\end{array}$ & $\begin{array}{c}\text { 3-4 accurate } \\
\text { populations of } \\
\text { animals and plants } \\
\text { listed. }\end{array}$ & $\begin{array}{c}\text { 1-2 accurate } \\
\text { populations of } \\
\text { animals and plants } \\
\text { listed. }\end{array}$ & $\begin{array}{l}\text { Inaccurate listing } \\
\text { of populations of } \\
\text { animals and plants. }\end{array}$ \\
\hline Human Uses & $\begin{array}{c}\text { Accurate and } \\
\text { detailed examples } \\
\text { of both postive } \\
\text { and negative uses. }\end{array}$ & $\begin{array}{l}\text { Accurate examples } \\
\text { of both positive } \\
\text { and negative uses. }\end{array}$ & $\begin{array}{c}\text { Accurate examples } \\
\text { of either positive } \\
\text { or negative (not } \\
\text { both) uses. }\end{array}$ & $\begin{array}{l}\text { Inaccurate } \\
\text { description of } \\
\text { human uses. }\end{array}$ \\
\hline Sustainability & $\begin{array}{c}\text { Accurate and } \\
\text { detailed } \\
\text { description of how } \\
\text { ecosystem can be } \\
\text { supported in a } \\
\text { sustainable way. }\end{array}$ & $\begin{array}{c}\text { Accurate } \\
\text { description of how } \\
\text { ecosystem can be } \\
\text { supported in a } \\
\text { sustainable way. }\end{array}$ & $\begin{array}{l}\text { Description of how } \\
\text { ecosystem can be } \\
\text { supported, but not } \\
\text { in a sustainable } \\
\text { way. }\end{array}$ & $\begin{array}{c}\text { Inaccurate } \\
\text { description of how } \\
\text { ecosystem can be } \\
\text { supported in a } \\
\text { sustainable way. }\end{array}$ \\
\hline Value & $\begin{array}{l}\text { Value of } \\
\text { ecosystem is } \\
\text { promoted through } \\
\text { brochure and } \\
\text { presentation. }\end{array}$ & $\begin{array}{l}\text { Value of } \\
\text { ecosystem is } \\
\text { promoted through } \\
\text { brochure or } \\
\text { presentation (not } \\
\text { both). }\end{array}$ & $\begin{array}{l}\text { Value of ecosystem } \\
\text { is vaguely implied. }\end{array}$ & $\begin{array}{c}\text { Value of ecosystem } \\
\text { is not mentioned } \\
\text { or implied. }\end{array}$ \\
\hline
\end{tabular}

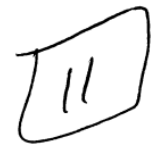




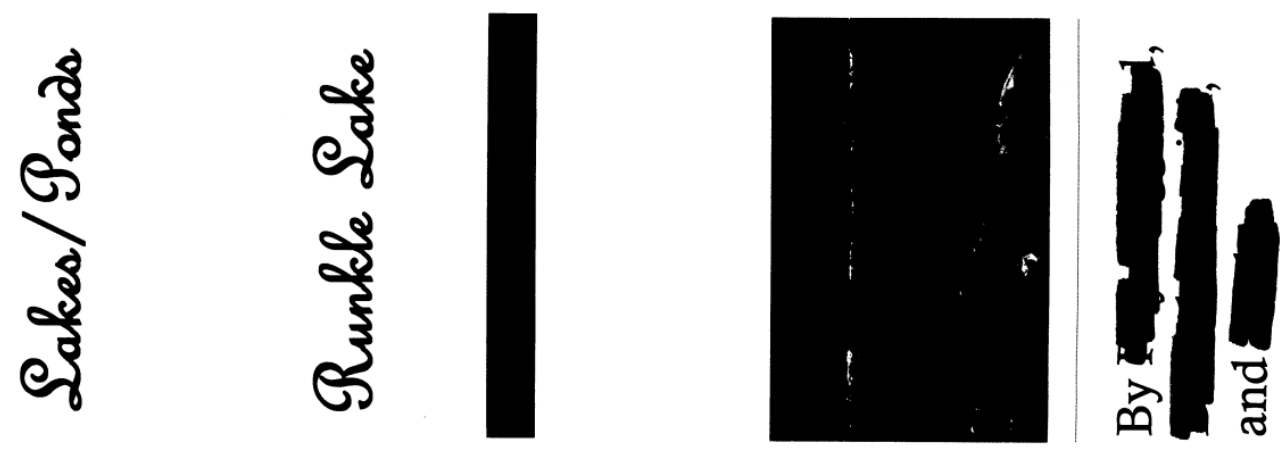

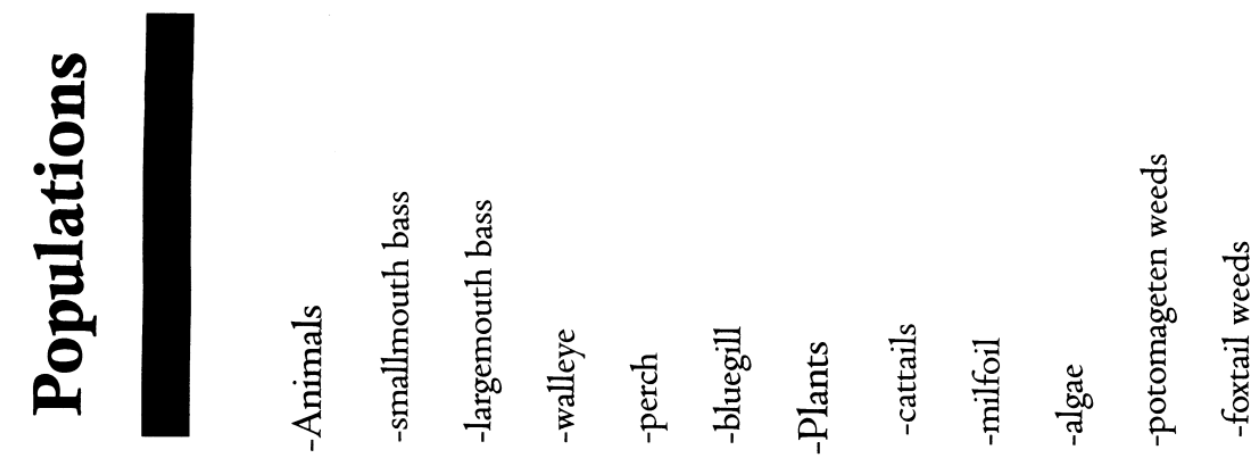

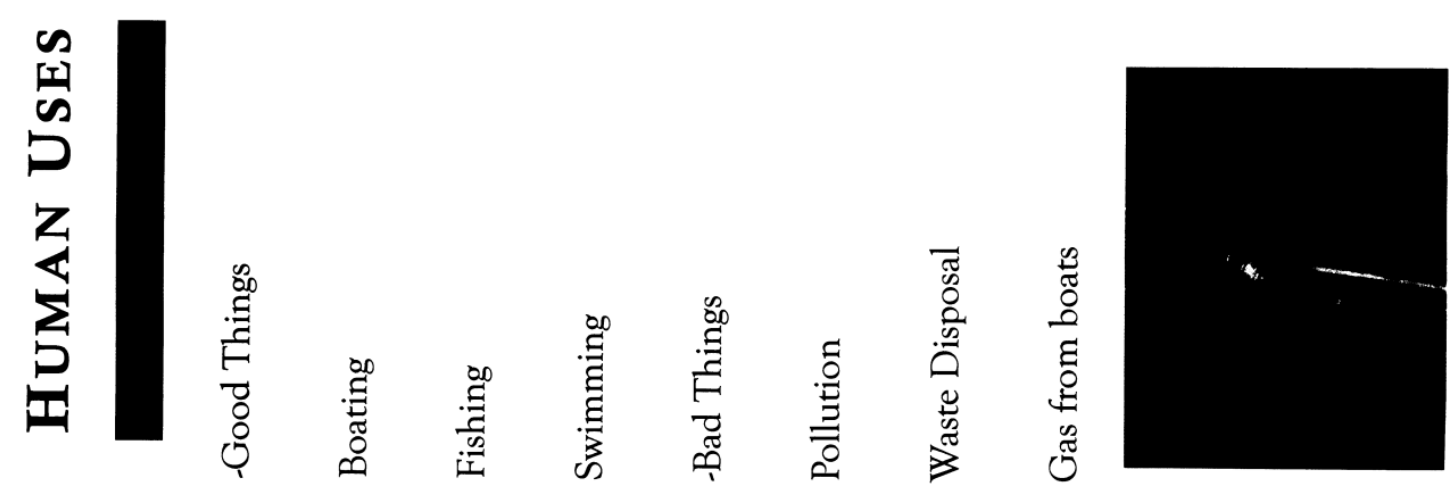



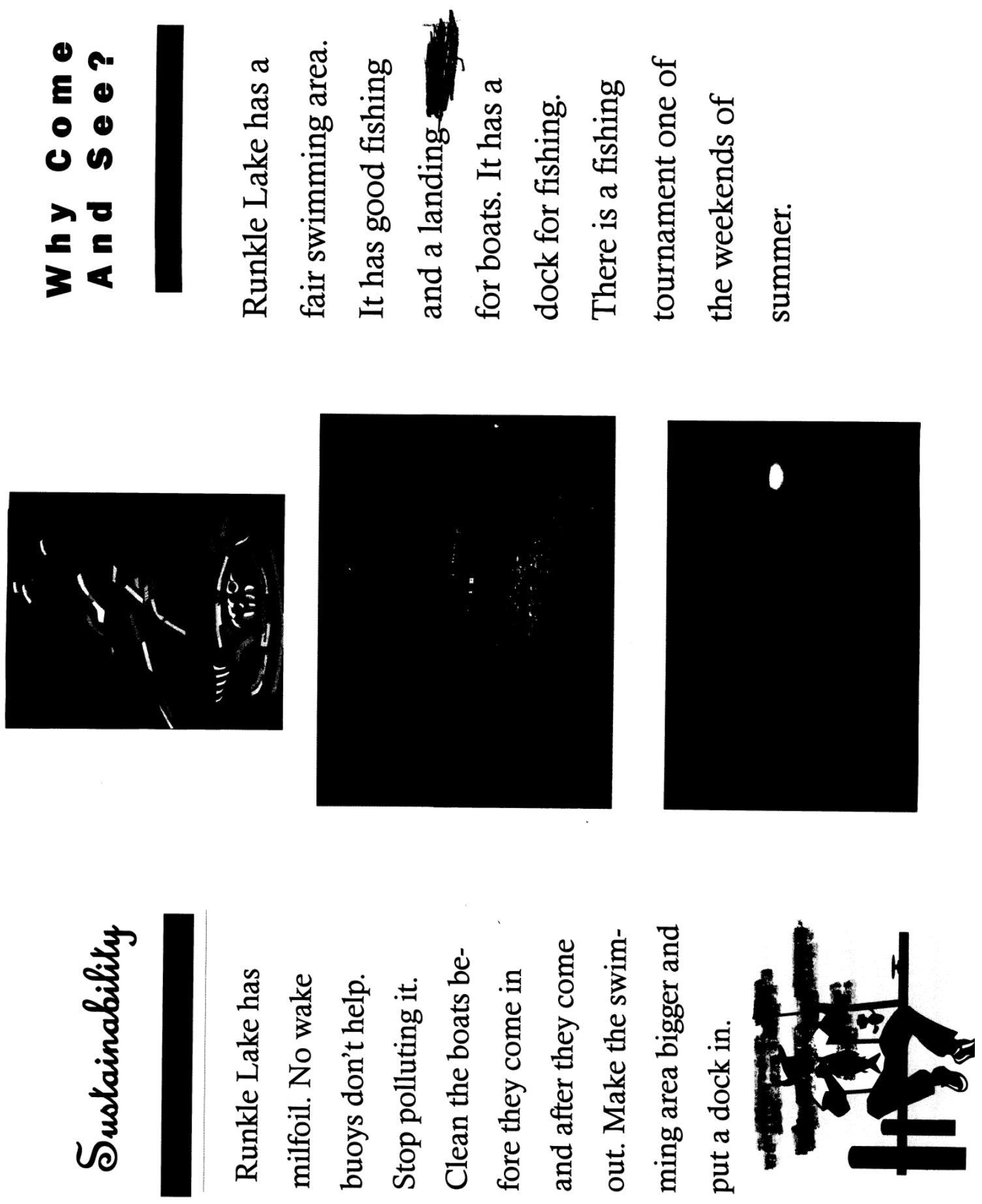
This page deliberately blank 


\section{Appendix E. Relationships of Organisms Subunit Resources}

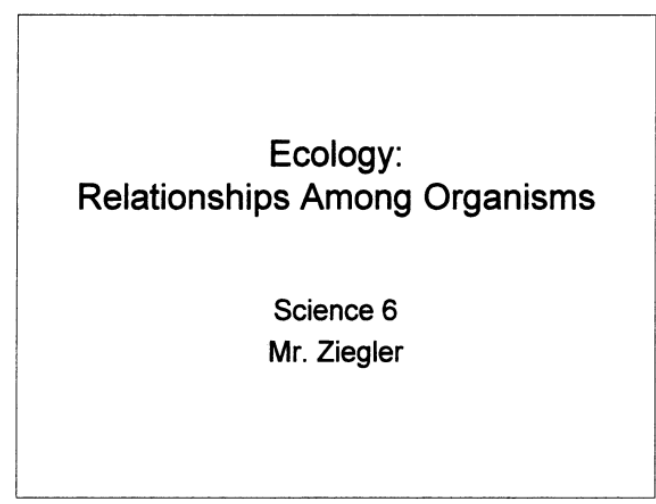

\section{Community}

- Group of various species that live in the same habitat and interact with each other

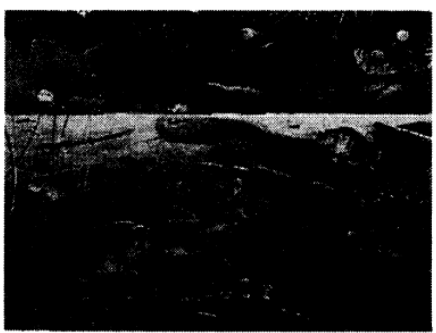

\section{Species Interactions}

- Predation

- Competition

- Parasitism

- Mutualism

- Commensalism

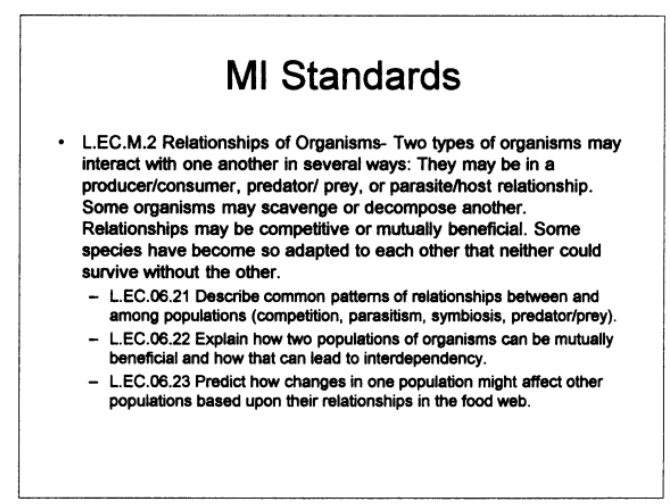

- Interdependence: interconnectedness (depend on each other)

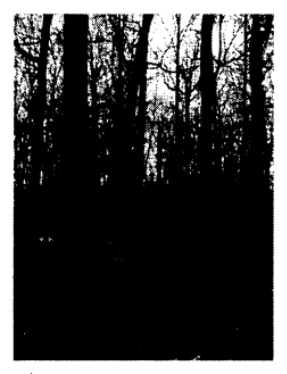

\section{Predation}

- Interaction in which one organism (the predator) captures and eats all or part of another individual organism (the prey)

- Example: Wolves and Moose on Isle Royale 

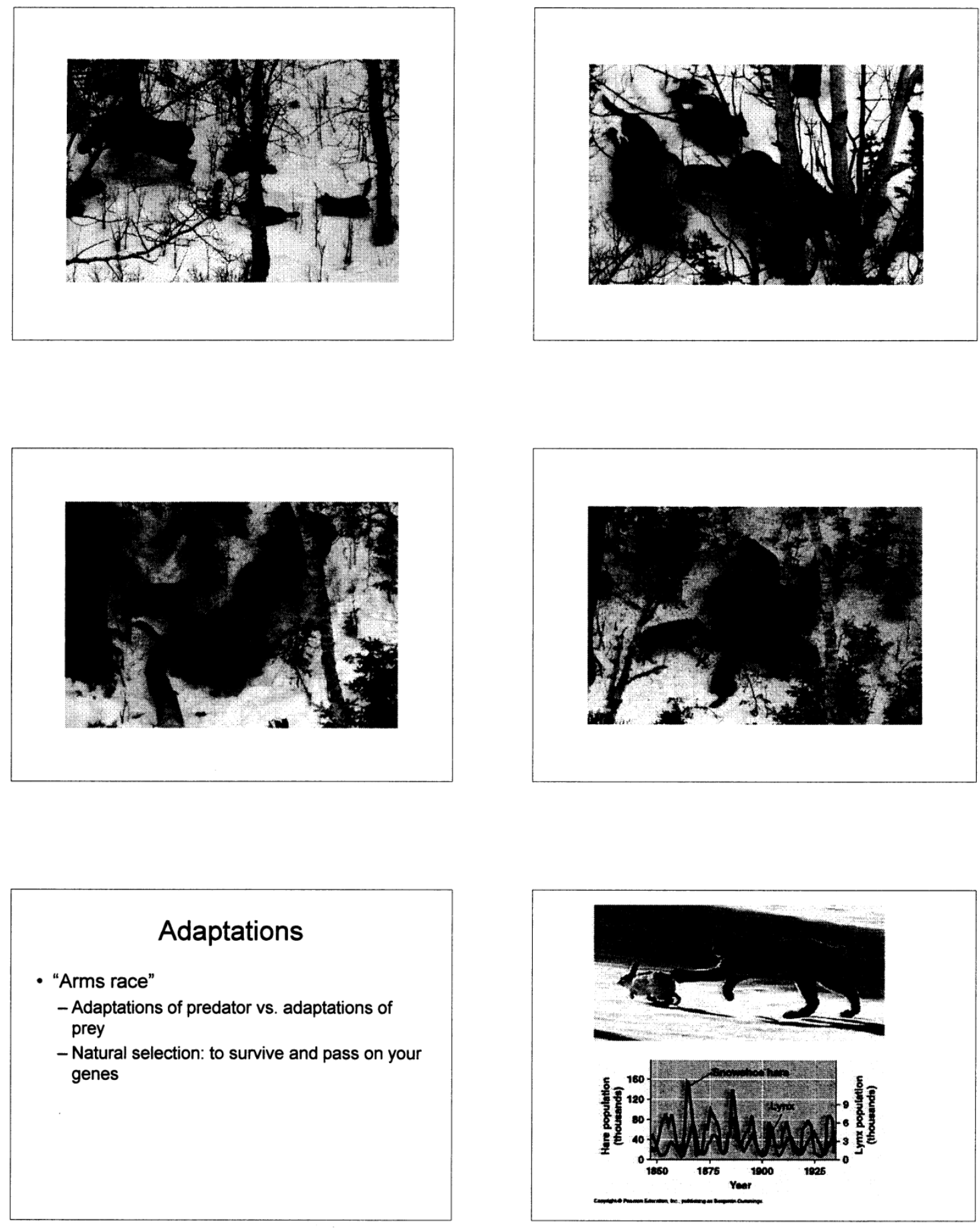


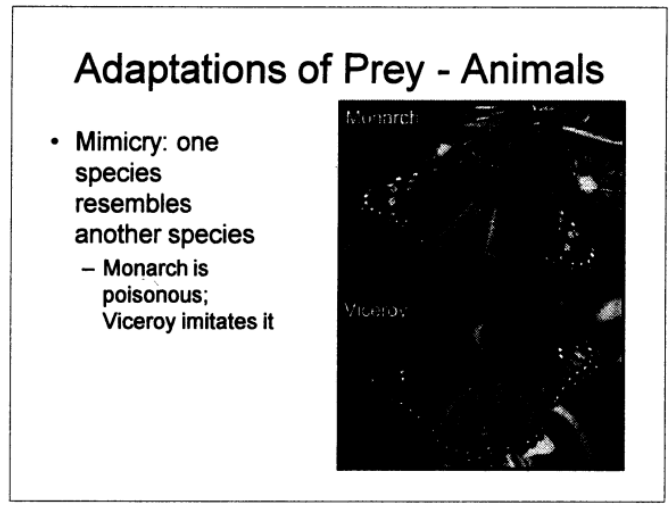

\section{Adaptations of Prey - Animals}
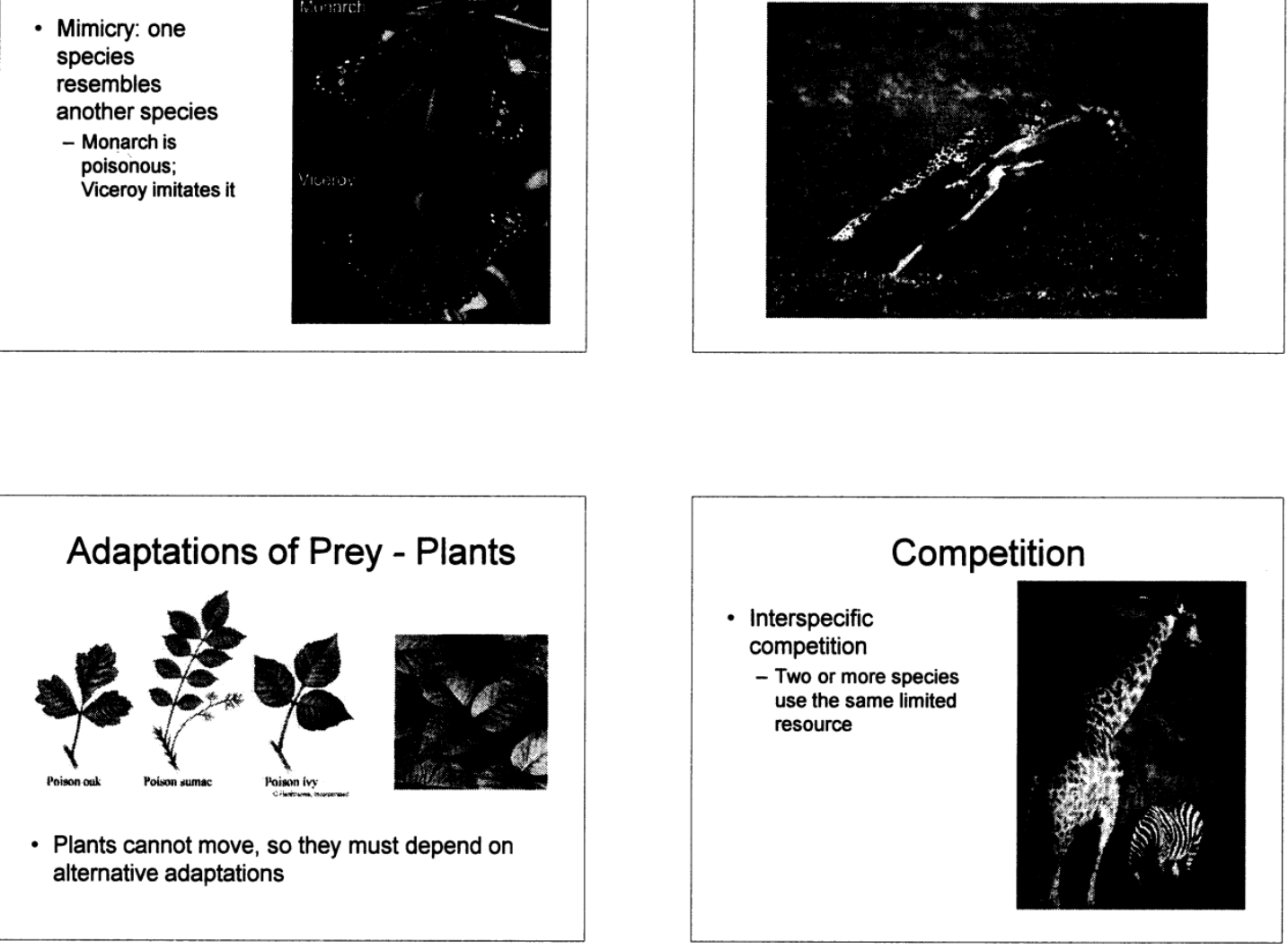

\section{Competition}

- Results in:

- Competitive exclusion

- One species is eliminated

- Reduced niche size

- Niche of a species is different with competition - Fundamental niche vs. Realized niche

- Character displacement

- Niches may change

- Resource partitioning

- Species share (use a specific part of resource)

\section{Symbiosis}

- Close, long-term relationship between two organisms

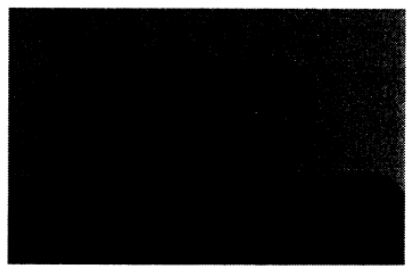




\section{Parasitism}

- + ,

- Parasite benefits, host harmed

- Parasite does not immediately kill host (different from predation)
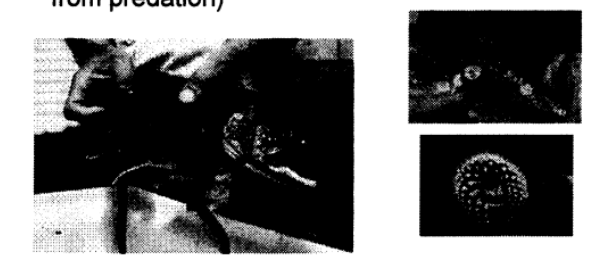

\section{Commensalism}

$+, 0$

- One species benefits, other species not affected
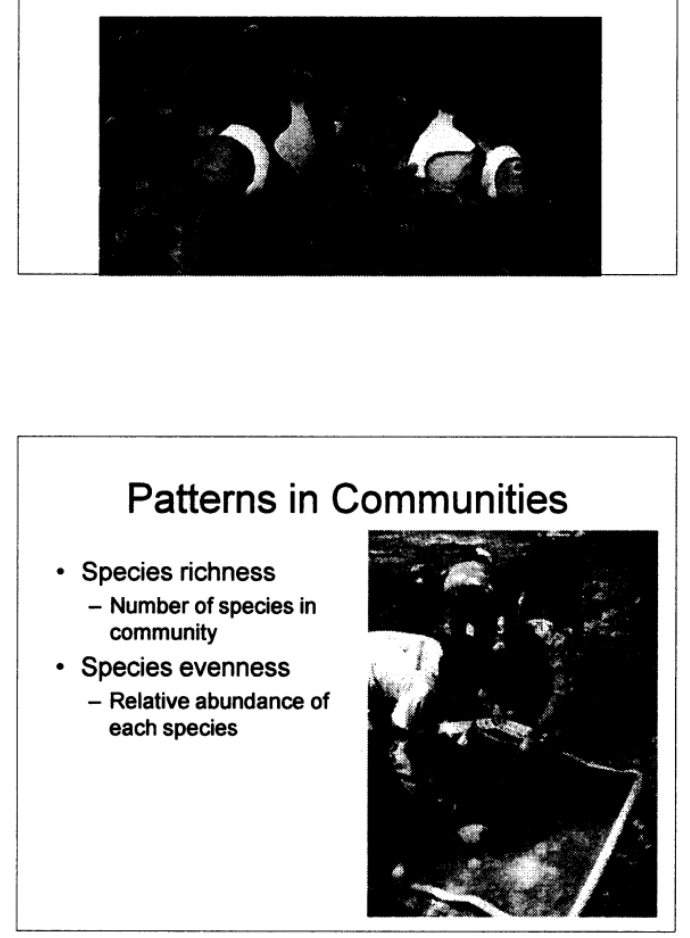
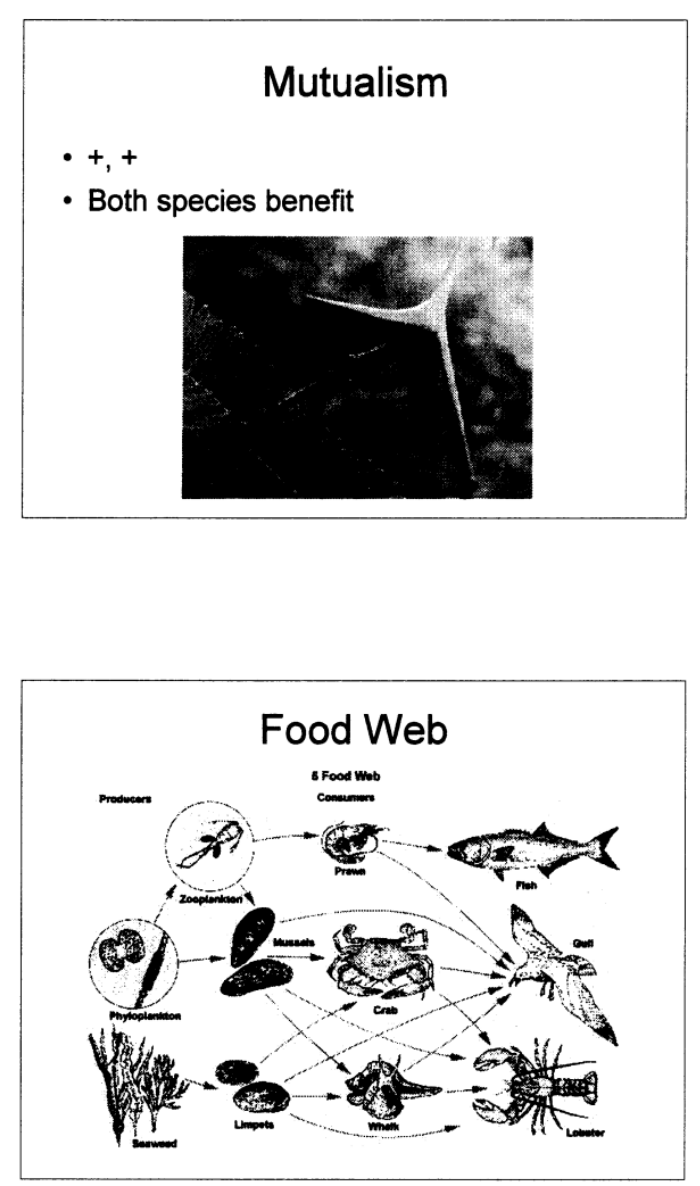


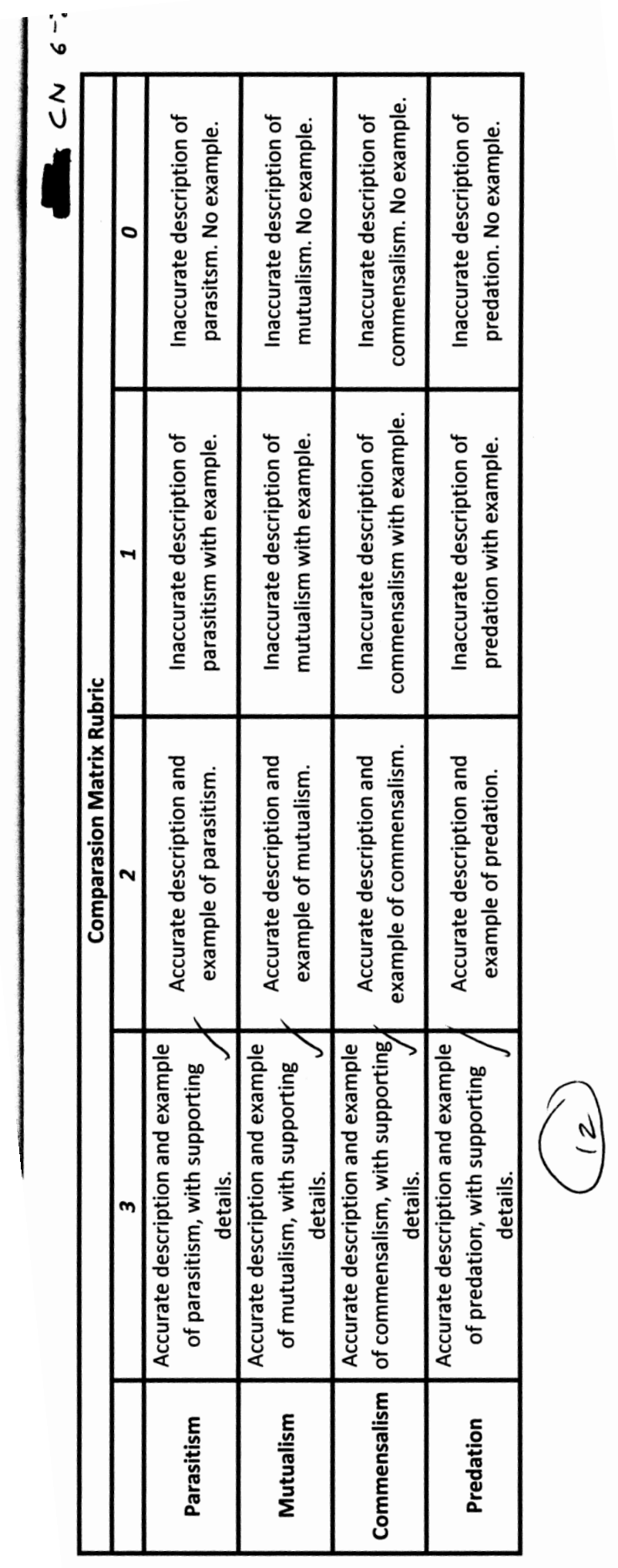




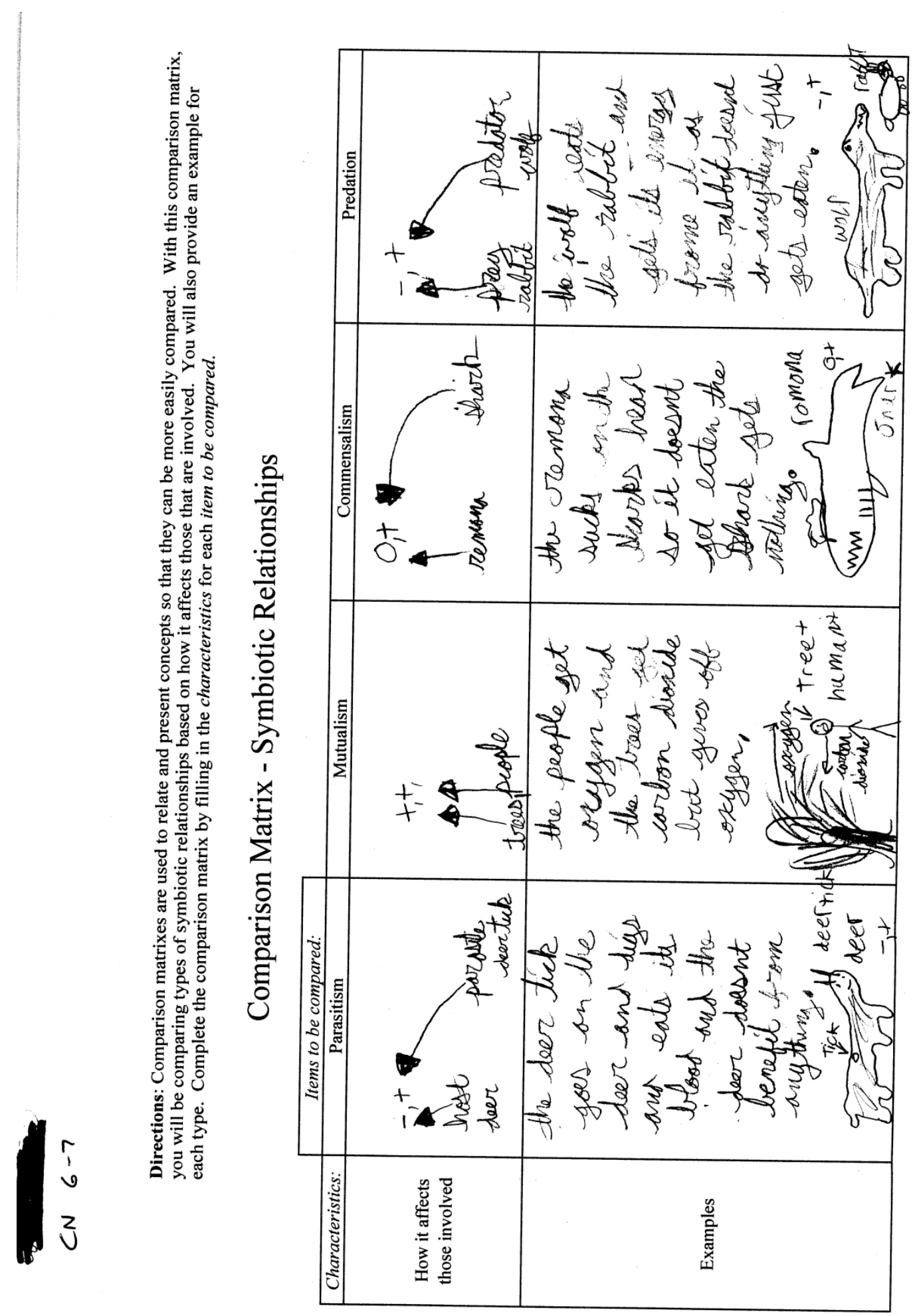




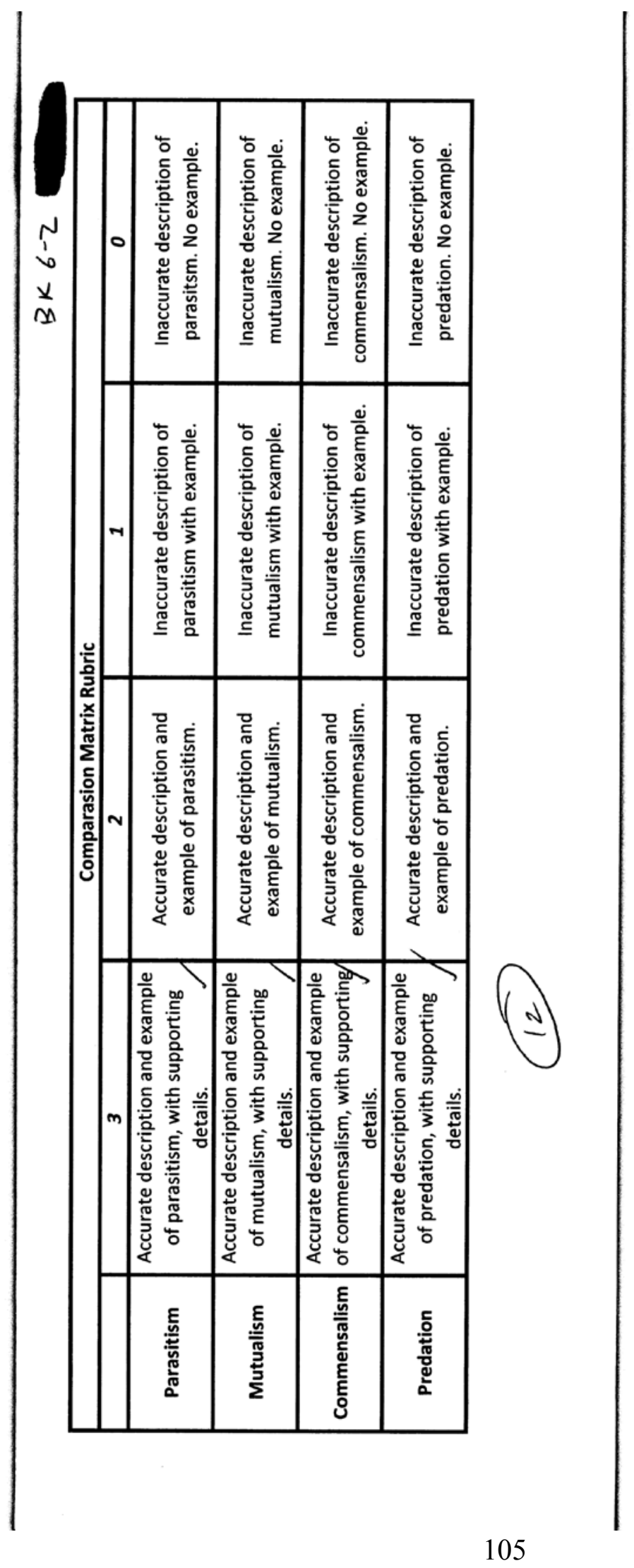




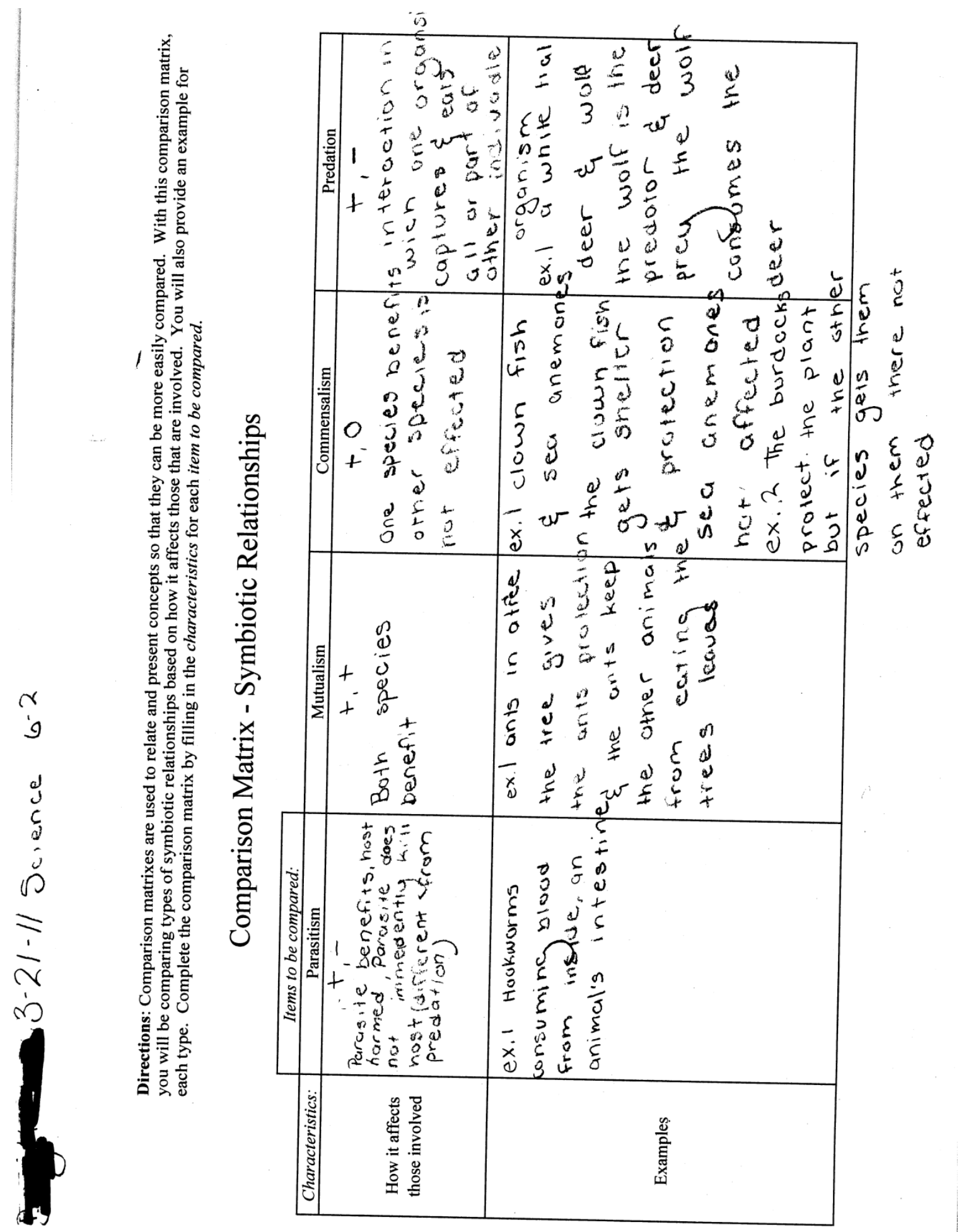




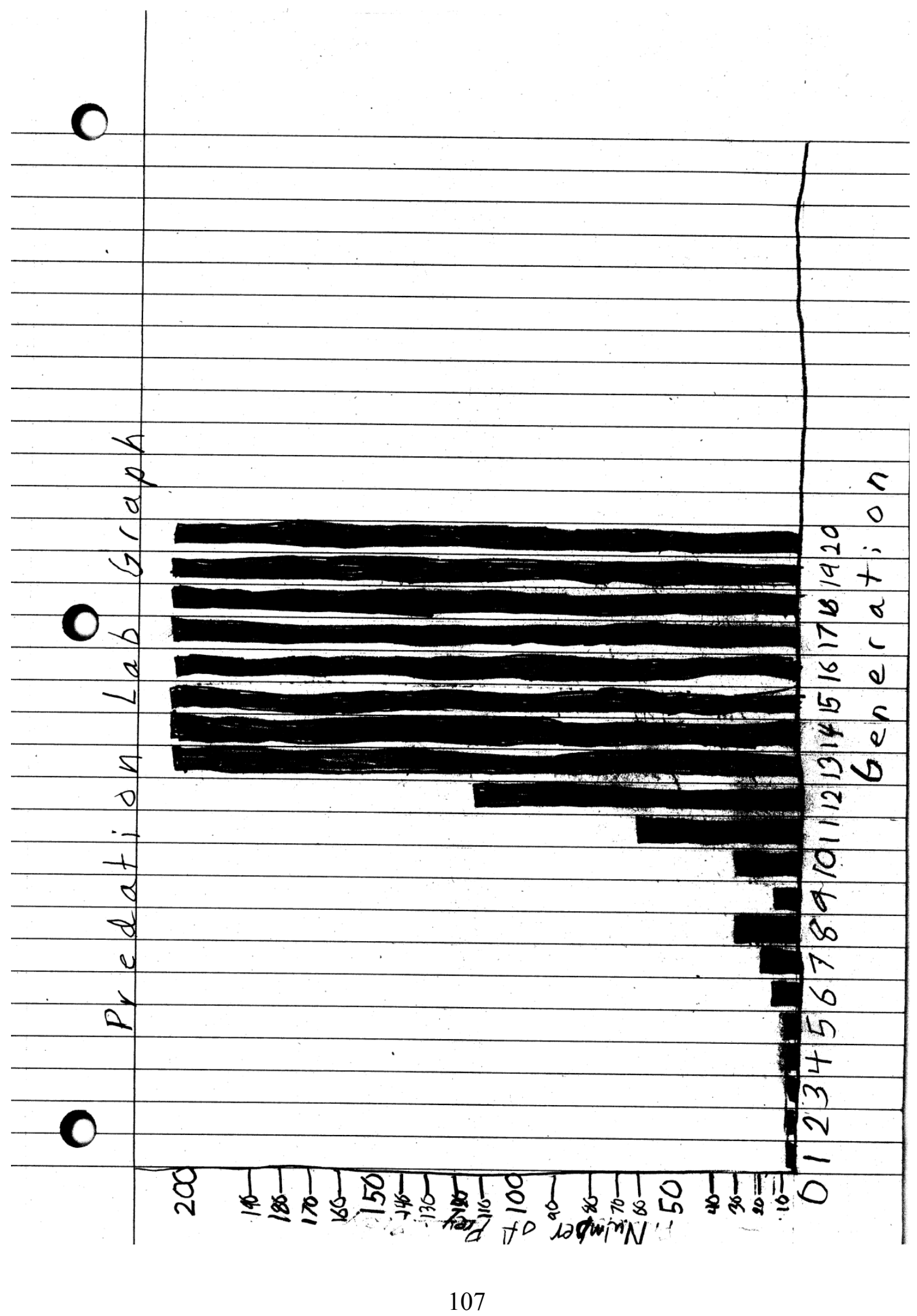


Assumption e

births

Leer offspring (male/temale?) I per generation

2. Deaths beyond predation

climate, diseases, resources, old age, haunting, accidents

3. No migration of prey

4. 200 max (carrying capacity)

Predation id Conieguskont

I learned that the prey

- Multiplied much easier tho the

Hid tors. Some errors we made

* having different people to s

tredarys. We could ix this

7 having a specific person toss,

14 better, we could design to

In way this lab simulates a

6 Int the predator sometimes tails

10 get enough; or any prey. Assumptions

I made were predicting that the

predator would succeed to $k$ ill the prey.

i)

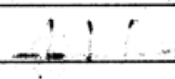

108 


\section{Relationships of Organisms Quiz}

\section{Multiple Choice}

Identify the choice that best completes the statement or answers the question.

1. The diagrams below show different kinds of interactions between species.

The ant keeps predators away from the acacia tree.

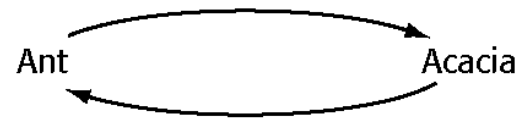

The acacia provides shelter and food for the ant.

1

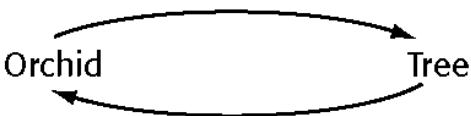

The tree provides nutrients and a sunlit location for the orchid living on it.

3
The cow eats grass.

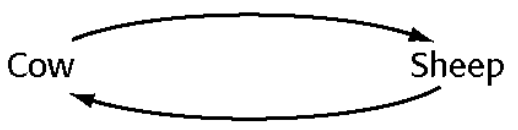

The sheep eats the same grass.

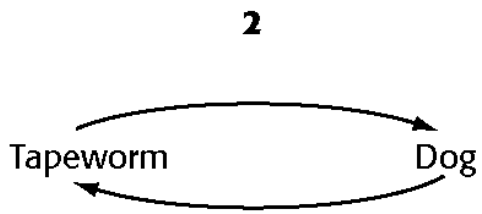

The dog provides nutrients and shelter for the tapeworm living in its intestines.

4

Refer to the illustration above. The relationship shown in diagram 4 is
a. commensalism.
b. competition.
c. mutualism.
d. parasitism.

2. Refer to the illustration above. The relationship shown in diagram 2 is
a. commensalism.
b. competition.
c. mutualism.
d. parasitism.

3. Refer to the illustration above. The relationship shown in diagram 1 is
a. commensalism.
b. competition.
c. mutualism.
d. parasitism.

4. Refer to the illustration above. The relationship shown in diagram 3 is
a. commensalism.
b. competition.
c. mutualism.
d. parasitism. 
5.

\begin{tabular}{|c|c|}
\hline 1 & Both organisms benefit from the activity of each other. \\
\hline 2 & $\begin{array}{l}\text { One organism benefits, and the other organism neither } \\
\text { benefits nor suffers harm. }\end{array}$ \\
\hline 3 & $\begin{array}{l}\text { One organism obtains its nutrients from another, and } \\
\text { the other organism may weaken due to deprivation. }\end{array}$ \\
\hline
\end{tabular}

Refer to the chart above. The table represents three types of
a. competition.
b. rhythmic patterns.
c. symbiosis.
d. secondary succession.

\section{Relationships of Organisms Quiz Answer Section}

\section{MULTIPLE CHOICE}

1. D

2. B

3. $\mathrm{C}$

4. A

5. C 


\section{Appendix F. Abiotic and Biotic Factors Subunit Resources}

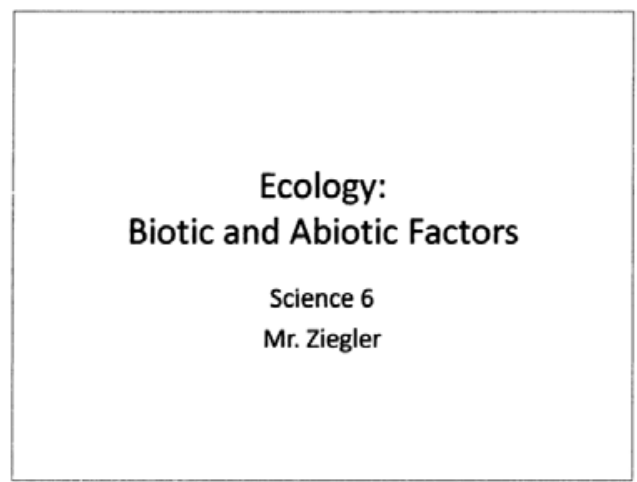

\section{Ecosystem Components}

- Biotic Factors

- All living things that affect the organism

- Abiotic Factors

- Nonliving (physical and chemical)

- Temperature, humidity, pH, salinity, $\mathrm{O} 2$ concentration, amount of sunlight, etc...

\section{Dealing with Change}

- Tolerance Curve

- Acclimation

- Control of Internal Conditions

- Escape

- Dormancy

- Migration

\section{Standards}

- L.EC.M.3 Biotic and Abiotic Factors- The number of organisms and populations an ecosystem can support depends on the biotic (living) resources available and abiotic (nonliving) factors, such as quality of light and water, range of temperatures and soil composition.

- L.EC.06.31 Identify the living (biotic) and nonliving (abiotic) components of an ecosystem.

- L.EC.06.32 Identify the factors in an ecosystem that influence changes in population size.

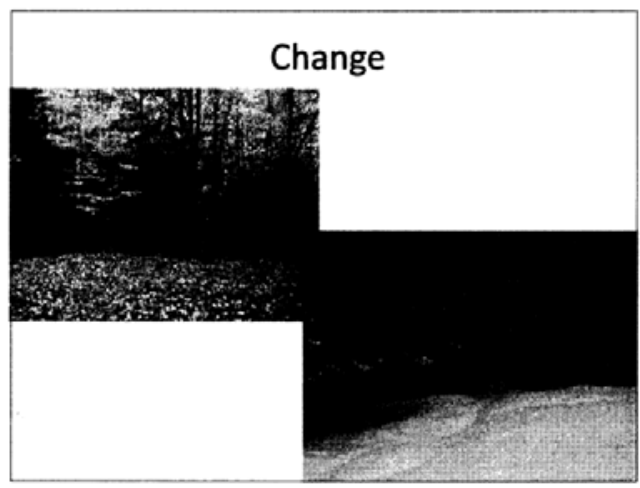

\section{Niche}

- Specific role (job) of an organism

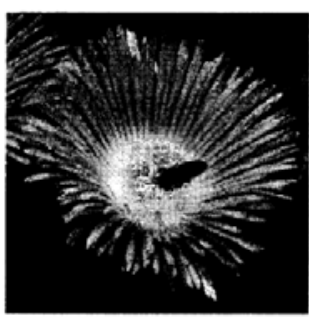




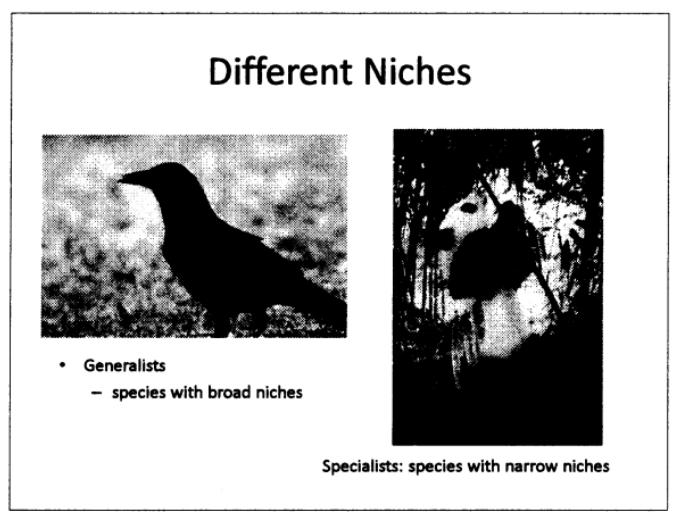

\section{Earth's Cycles}

- Flow of Matter and Energy

- Continuously flows through biotic and abiotic factors in an ecosystem

- Biogeochemical cycles
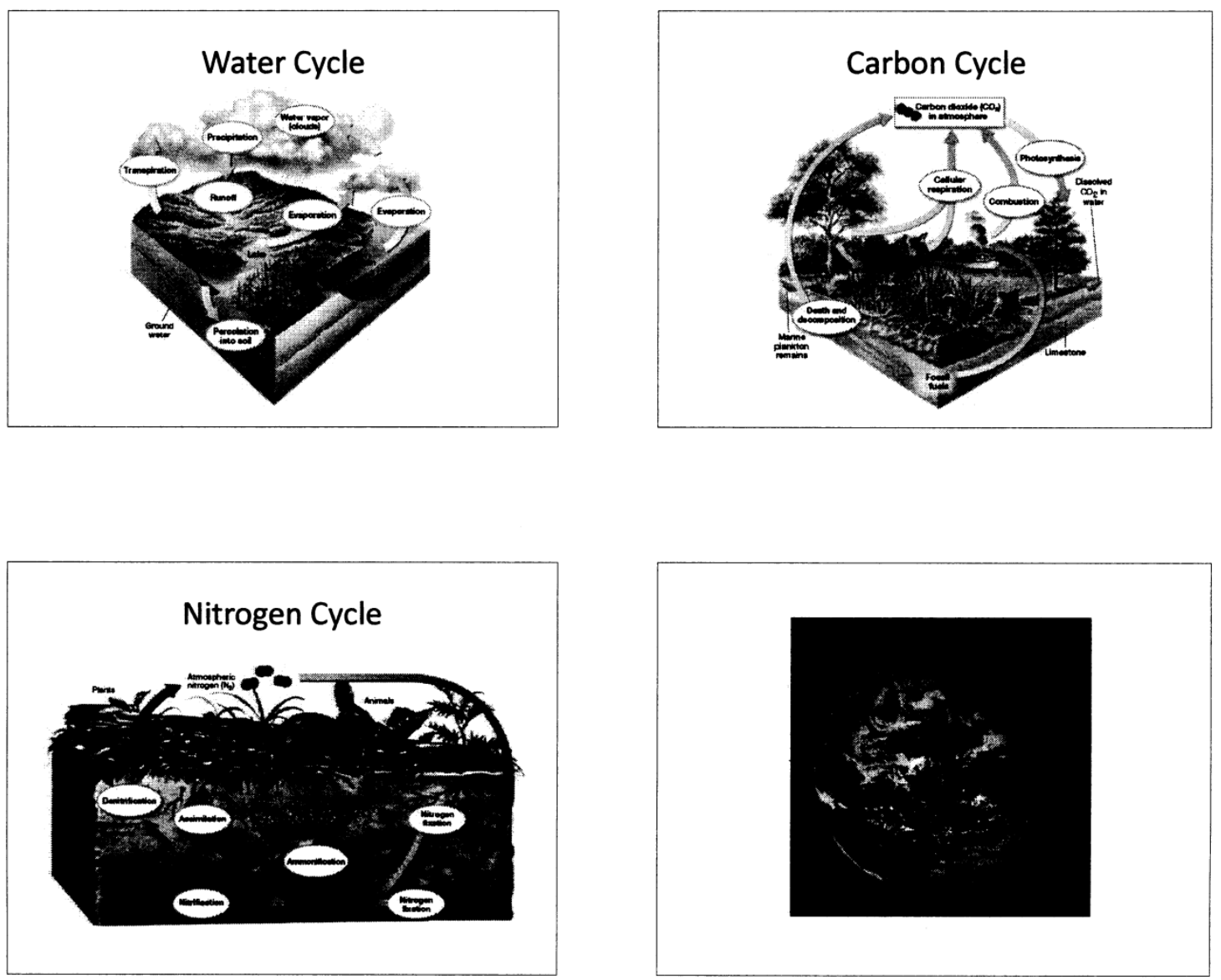


\section{Appendix G. Environmental Impacts of Organisms Subunit Resources}

\begin{tabular}{|} 
Environmental Impacts of \\
Organisms \\
Issues in Your World \\
Science 6 \\
Mr. Ziegler
\end{tabular}
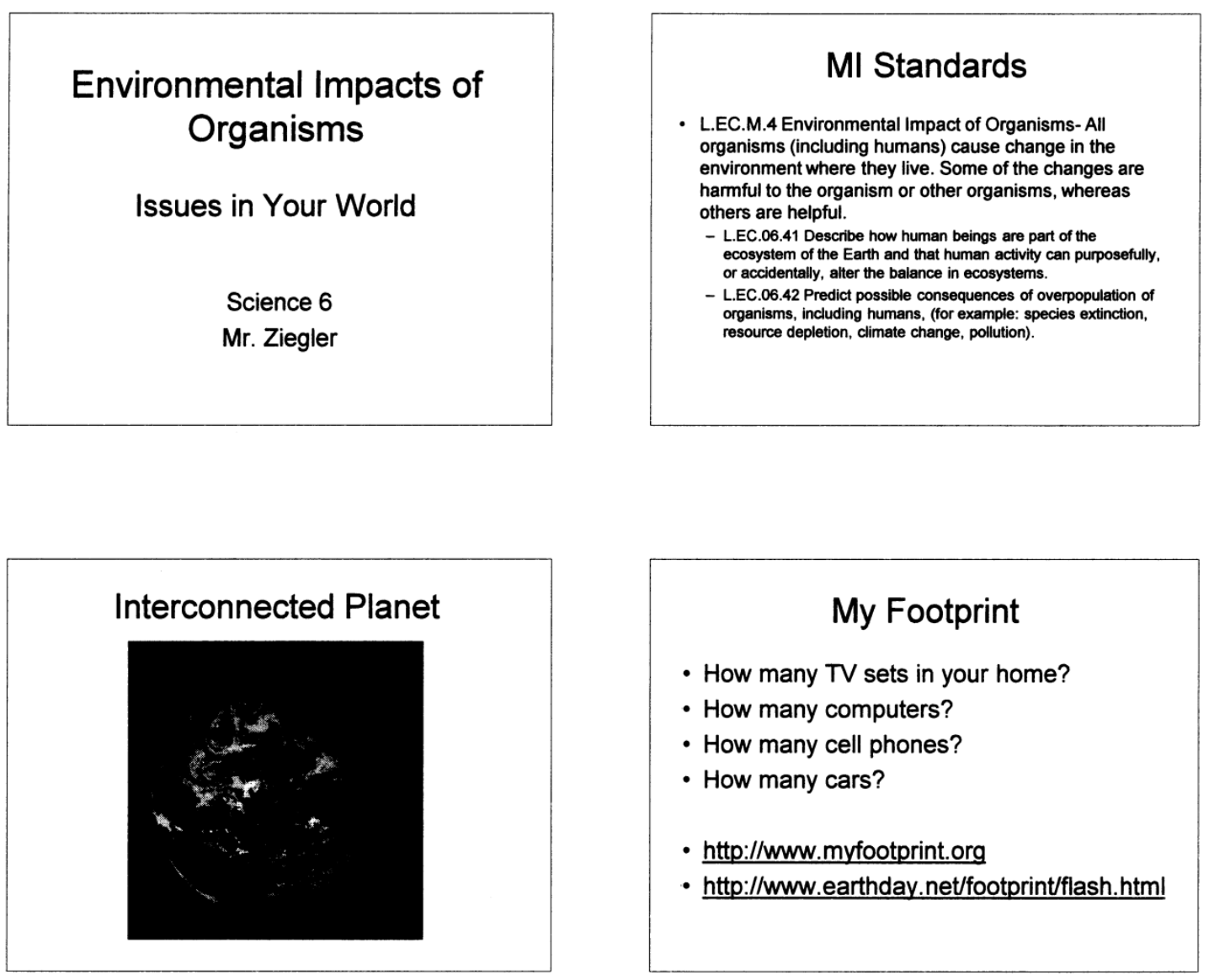

\section{My Footprint}

- How many TV sets in your home?

- How many computers?

- How many cell phones?

- How many cars?

- http://uww.myfootprint.org

- http://www.earthday.net/footprint/flash.html

The range of interactions with the environment.

- Developing countries: people are closely tied to their environment.

- Industrialized countries: people appear to be detached from their environment.
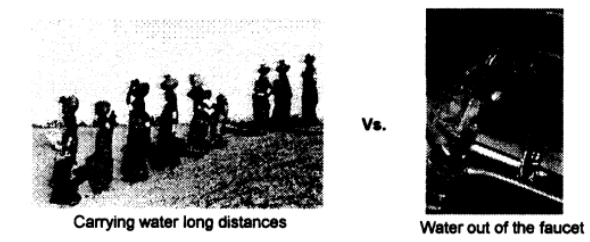

- Human societies, whether they appear to be closely tied to their environment or not, are absolutely dependent on the natural environment, and their impact on the environment is crucial for their continued success. 

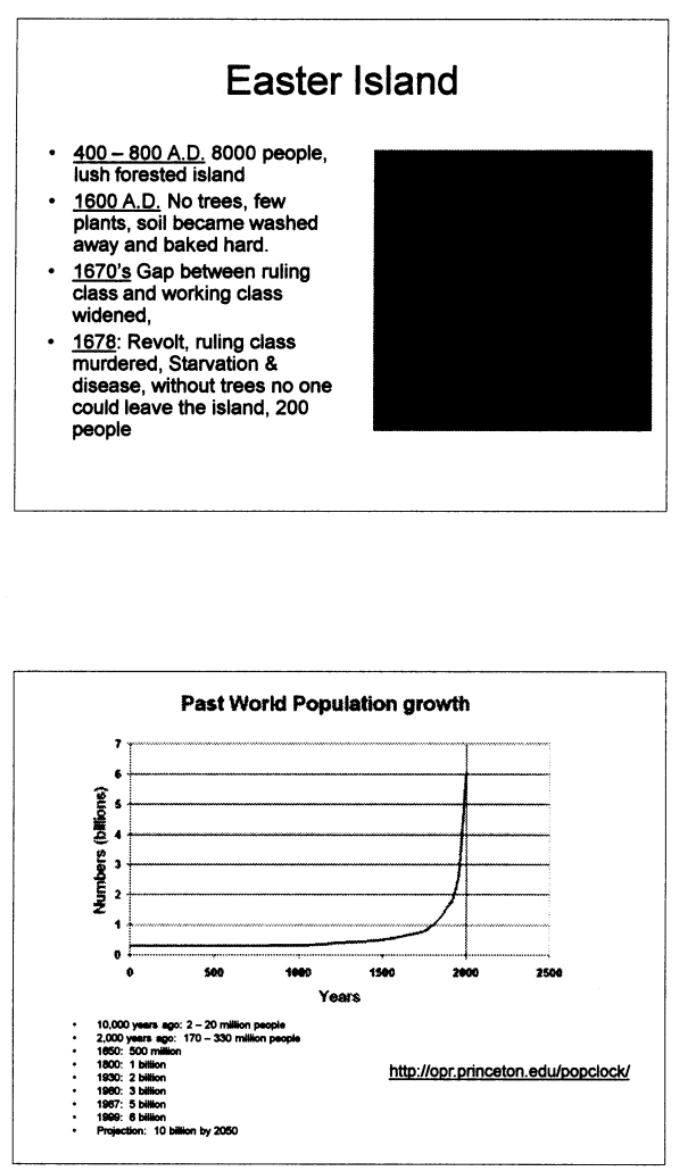

\section{Human Population Growth}

- http://www.pbs.org/wgbh/nova/worldbalance/

- Each person creates a demand on Earth's resources

- In general: the more affluent, the greater the demand.

- Stresses: groundwater, soils, oceans overfished, oil reserves, trees cut down faster than can be forested

- hitp://hmw.pbs.org/wgbh/nova/worldbalance/earth.htm!

\section{Moral:}

- When a society fails to care for the environment that sustains it, when its population increases beyond the capacity of the land and water to provide adequate food for all, and when the disparity between haves and have-nots widens into a gulf of social injustice, the result is disaster.

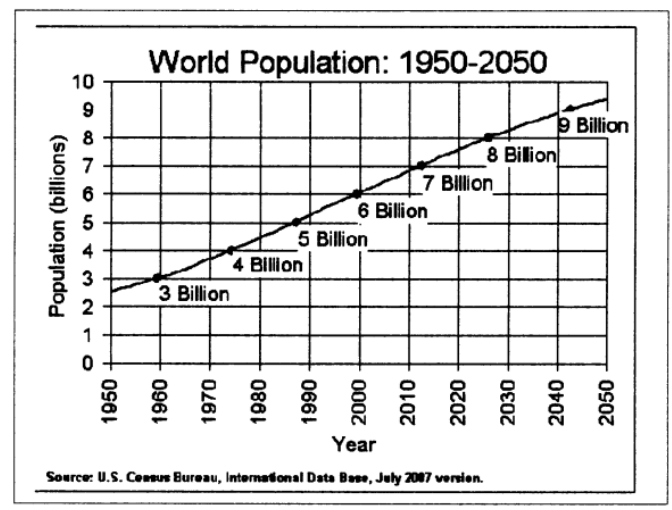

\section{The Global Environmental Picture}

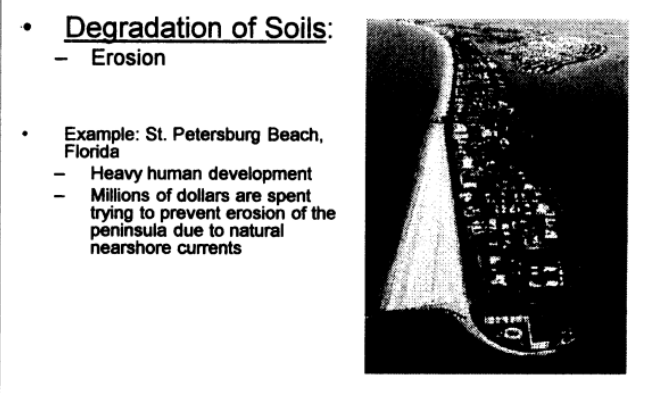


The Global Environmental Picture

- Degradation of Soils:

- Desertification

- http://soils.usda.gov/use/worldsoils/mapindex/desert.htm!

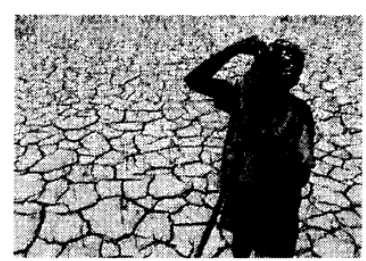

The Global Environmental Picture

\section{- Degradation of Soils}

Development of
agricultural lands

In Development's Path
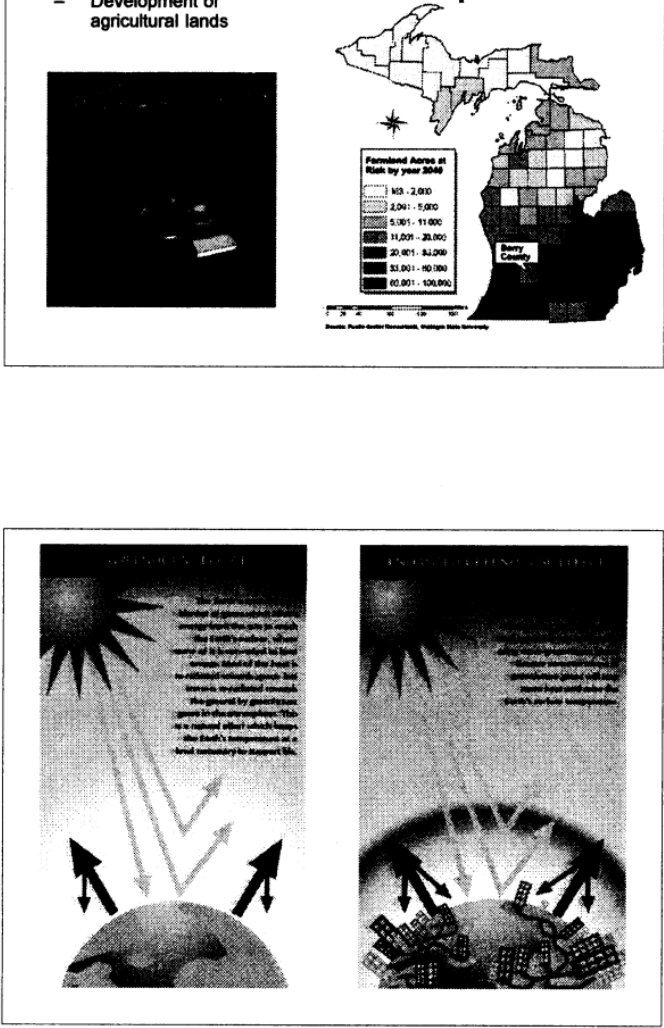

The Global Environmental Picture

- Degradation of Soils:

- Salt water irigation

- Example: Persian Gulf, caused by irrigation

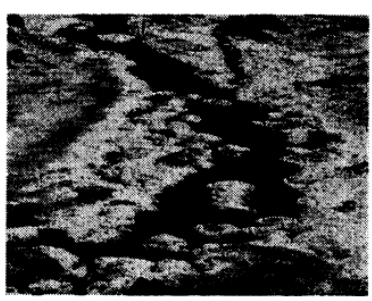

The Global Environmental Picture

- Global Atmospheric Changes:

- Burning of Fossil Fuel = Increased levels of $\mathrm{CO}_{2}$ $-\mathrm{CO}_{2}$

- Invisible to sunlight but absorbs infrared (heat) energy

- Increased levels of $\mathrm{CO}_{2}$ magnify greenhouse effect, warming the lower atmosphere

- 2005 was one of the hottest years of past century (NASA)

- 1900: 280 ppm; Today: 370 ppm

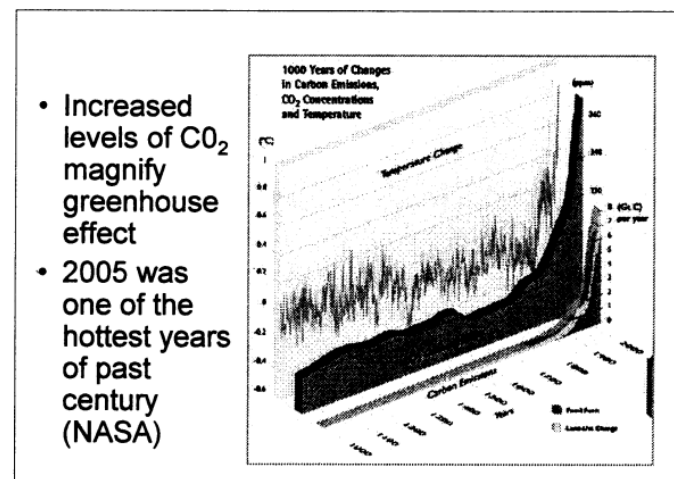




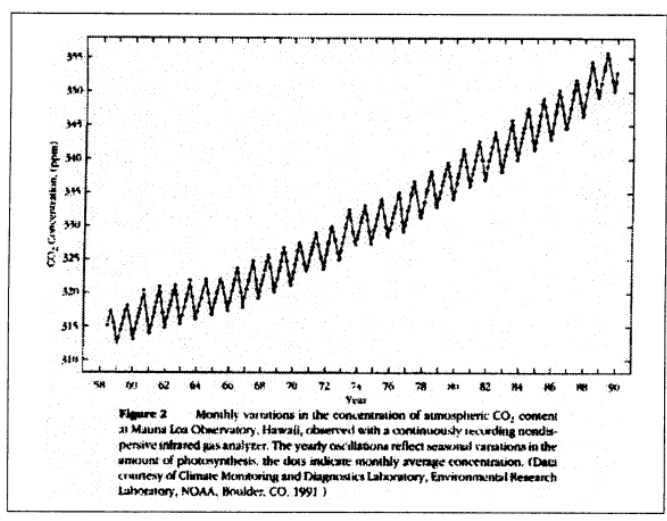

\section{The Global Environmental Picture}

- Ecosystem disruption

- Habitat alteration

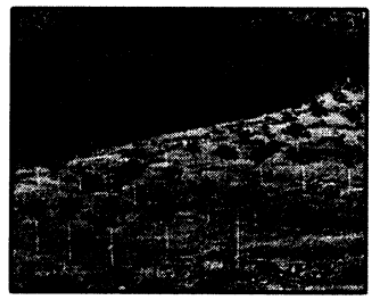

The Global Environmental Picture

- Ecosystem disruption

Loss of Biodiversity

Total diversity of all living things inhabiting our planet

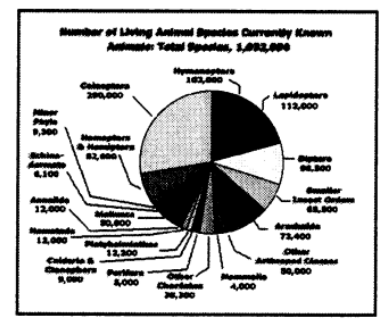

The Global Environmental Picture

- Ecosystem disruption

- Pollution

- Exploitation

- Imbalance

- Invasive species

- Extinction

- Why is it important? Domestic animals, medicine, agriculture, aesthetic \& moral. Do we have a mora responsibility to protect and preserve such animals and other species?

http://unww.iucnredlist.org/photos

\section{What Can You Do?}

- Sustainability

- Ability to meet human needs in such a way that a

human population can survive indefinitely

- How big is your ecological footprint?

- Take Action

- Local action = global effects

- http://uww.globalwarming101.com

\section{Interconnected Planet}

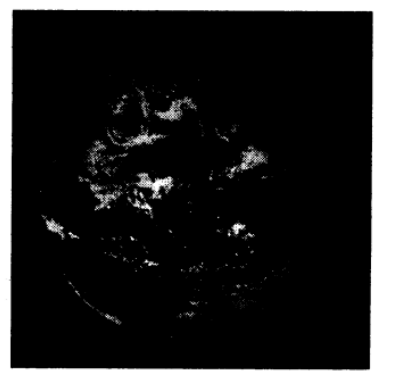



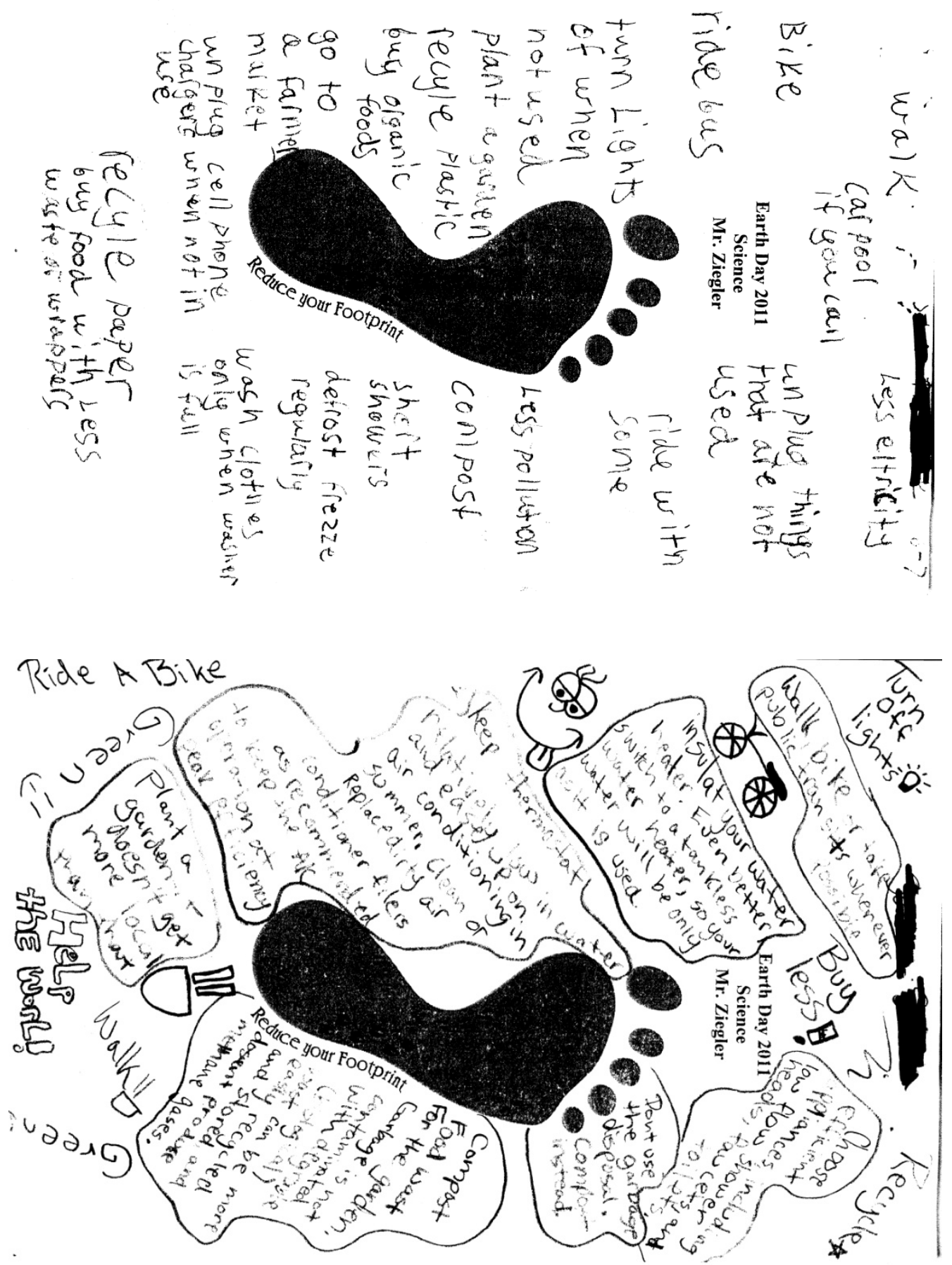


\section{Name TG 6-7 Class $6-5$}

Appendix I

Research Paper Rubric

The following rubric and point values will be used to evaluate your final research paper. Use this rubric to guide you through the drafting and editing process and to ensure you are meeting all requirements for this assignment.

$$
+x_{i}
$$

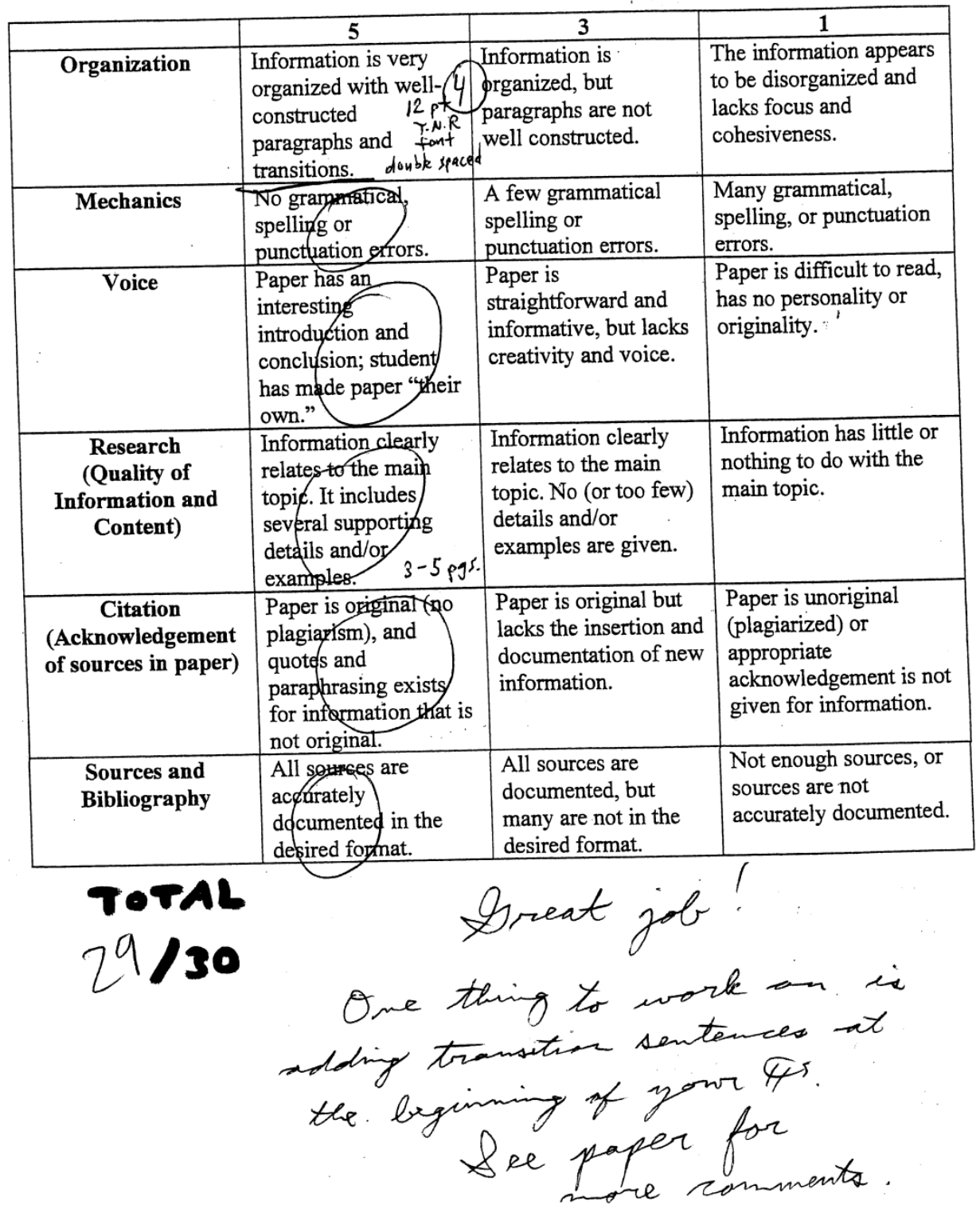




\section{JG 6.7}

Language Arts 6-5

Research Paper

May 20, 2011

\section{My Housing Footprint}

Did you know that if every person lived like me, lived in the same house, and did the $x_{x^{5}}^{e^{\text {ele }}}$ same things, it would take five earths to support all people on earth! If you are looking for ways to reduce your housing footprint, come along and soak your brains in some interesting research about housing and how we save the earth. In this research paper, I'm going to talk about how to adopt water saving habits, how to choose sustainable building materials, and how you should always recycle.

\section{Water saving habits}

When you adopt water saving habits, it is difficult to change your daily patterns, but when you do change them, you will be happy. You will save money and the environment. You should take shorter, less frequent showers. This not only saves water, soves but also the energy necessary to heat it, and that's cool. Run your dishwasher and the laundry only when it is full because it will save you energy and water. Wash cars rarely,

for or even better yet, take your car to the carwash. Even though you will spend money, you fese fer will save water. You know that you may need to use your garbage disposal, but it uses lots of water. You can compost instead. Of course you should fix all leaks and do it regularly. If you have a garden, you should water it early in the morning, because N watering in the afternoon causes water to evaporate during the hottest part of the day. 
If you live by a lake

Okay, let's say you have a farm with lots of animals, and they use a lot of water. You need to save money, so you should farm by a lake because the water could be used for your animals, and it would be clean water. So you can save money by doing that. If you want an inflatable pool which has to be filled up every year, you car save the planet by moving by a lake. You could have an in the ground pool and to save energy by never letting the water out axd you can let the sun warm the pool in the summer time. When you have a garden in the summer time, you can use the lake water to moisten your beautiful garden. Remember, you can save lots of money and the PLANET by just living

near a lake!!!

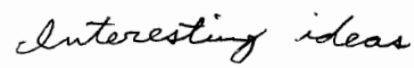

ib

Recycling<smiles>[Te]</smiles>

Recycling is an important part of gre daily lives. When you recycle paper products, you can save trees. Just think every time you recycle a paper product you can say to your friends, or in your mind, "I'm saving a tree right now." Now listen to this!

Recycling has always been a part of our culture. In the 1920 's, $70 \%$ of cities ran programs recycling certain materials. During World War II, industry recycled about $25 \%$ of the waste stream. Today we recycle about $33 \%$ of the waste stream, and that $13 \%$ that went up. The benefits of recycling include saving energy, saving money, reducing air and water pollution, creating new jobs for people, preserving wildlife, and saving land space. Reduce the amount of trash you throw in the landfill by buying products with less packaging and only buying what you need.

By recycling, you can save money and not have much garbage on pick up day.

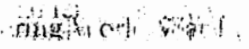




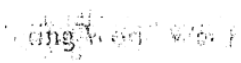

What's good for the environment?

Instead of factories making more tree products and plastic products, you can recycle Wut if you do not, the factories will make more and more bad air for the environment. It Recycling saves more trees instead of cutting them down for paper products when-can recycle Did you know that if you work hard and respect the environment you can save many things as well? Like what?

Sustainable building materials

Choose efficient appliances including low flow toilets, faucets, and shower heads. Now you probably never heard about "low flow toilets", and I had not heard about it either. Don't worry, because I will explain it to you. Less water is used to flush a toilet, and the toilet gets rid of waste with less water. Did you know that you can plant drought tolerant plants in your yard or your garden? You can choose furnishings that are secondhand, sustainable produced, or recycled. Explore green design features for your building, like a rainwater catchmentф, or grey water recycling system, recycled materials, and passive solar heating. Vele me more about thace!

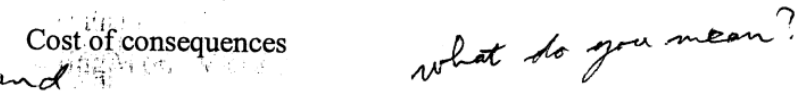

You can save energy which money by just picking low flow things. You will pay more money for plants that are not drought tolerant plants, and I would not want to do that. Apd of course it's more money for things that are not second-hand. Those things are important because it saves money, trees, and of course it will save the Earth. 


\begin{abstract}
Conclusion
$\therefore$ is

Remember that I said that if every person lived like me on earth it would equal five earths, and that is a lot. Now if you did all the things I said to do above, you would have fewer planets than I did. This could impact our future. Save the PLANET!!!
\end{abstract}

\title{
Bibliography
}

Bramble, Laura. "How To Find Out My Carbon Footprint." eHow.com. 13 May 2010.

Web. 5 May 2011.

Rahim, Supli. "Ewaste." Reducemyecofootprint.com. 2010. Web"4 May 2011.

Rahim, Supli. "We Save Money.” Reducemyecofootprint.com. 2010. Web.4 May 2011.

Rahim, Supli. "Reduce My Eco Footprint." Reducemyecofootprint.com. 2010. Web. 4

May 2011. 


\section{Appendix H. Stocking Permit from MI DNR}

Attachment 2. Public Waters Stocking Permit and Report

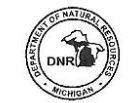

Michigan Department of Natural Resources - Fisheries Division

Permit To Stock Fish Into Michigan Public Waters

This permit is issued under the authority of Section 48735 of Part 487, Sport Fishing, of Act 451, P.A. 1994, as amended. Failure to comply with the conditions of this Act and permit shall be cause for revocation of this permit. The penalty for stocking fish into public waters of the state without a permit is a misdemeanor, punishable by imprisonment for not more than 90 days, or a fine of not more than $\$ 500.00$, or both.

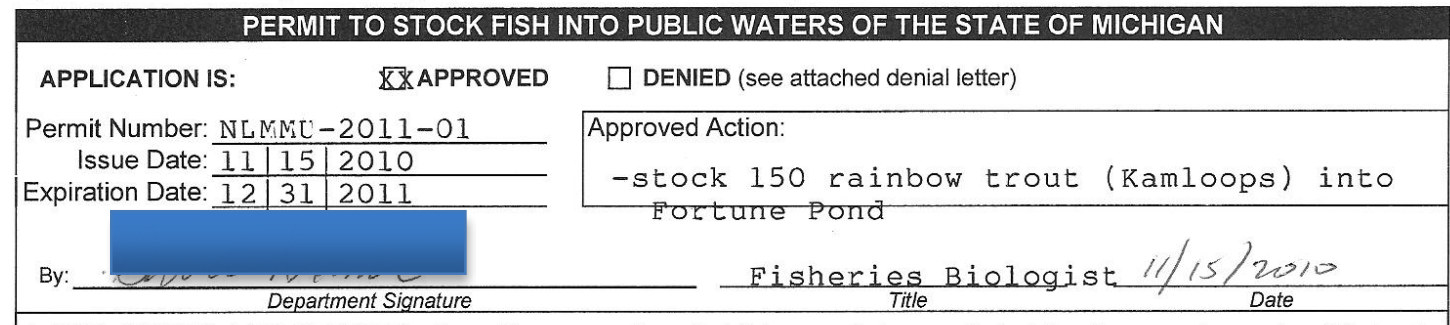

LAWS, CODES AND PERMITS. Permittee recognizes that this permit does not obviate other requirements of federal, state, or local law. Permittee agrees to comply with all applicable laws, regulations, and codes, and shall obtain any necessary permits in connection with the activities that are the subject of this permit.

LIABILITY. Permittee hereby releases, waives, discharges and covenants not to sue the State of Michigan, its departments, officers, employees and agents, from any and all liability to Permittee, its officers, employees and agents, for all losses, injury, death or damage, and any claims or demands thereto, on account of injury to person or property, or resulting in death of Permittee, its officers, employees or agents, in reference to the activities authorized by this permit.

INDEMNIFICATION. Permittee hereby covenants and agrees to indemnify and save harmless, the State of Michigan, its departments, officers, employees and agents, from any and all claims and demands, for all loss, injury, death or damage, that any person or entity may have or make, in any manner, arising out of any occurrence related to (1) issuance of this permit; (2) the activities authorized by this permit; and (3) the use or occupancy of the premises which are the subject of this permit by the Permittee, its employees, contractors, or its authorized representatives.

I have read the terms and conditions contained in this permit. I agree to abide by same and assume all the obligations contained herein. Approved applicants or their agent will be required to submit a report detailing the number and size of each species stocked.

Purchaser or Agent's Signature

Date

Detach and Submit Private Fish Stocking Report within 14 days of Stocking

Public WATERS StOCKINg REPORT

This report is required under the authority of Section 48735 of Part 487, Sport Fishing, of Act 451, P.A. 1994, as amended.

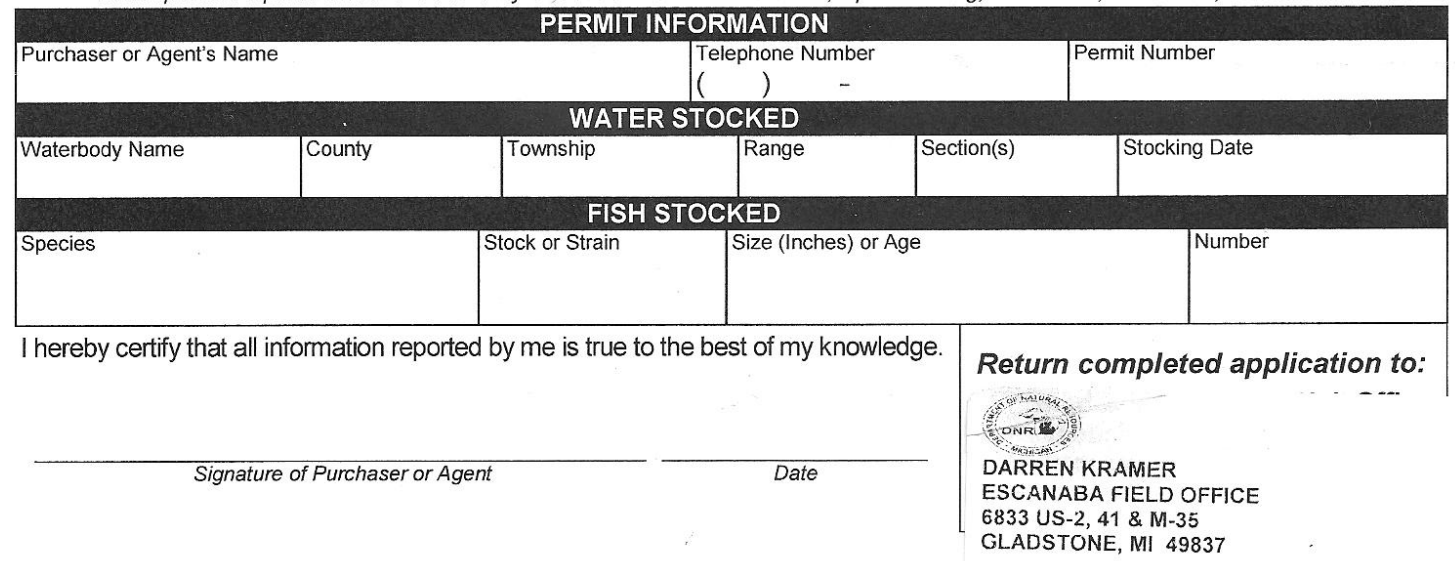


This page deliberately blank 


\section{Appendix I. Ecoposter Group Activity Rubric}

\begin{tabular}{|c|c|c|c|c|}
\hline \multicolumn{5}{|c|}{ Ecoposter Group Activity Rubric } \\
\hline & 3 & 2 & 1 & 0 \\
\hline $\begin{array}{l}\text { Producers, } \\
\text { consumers, } \\
\text { decomposers }\end{array}$ & $\begin{array}{c}\text { Accurate } \\
\text { description and } \\
\text { example of food } \\
\text { chain with } \\
\text { supporting } \\
\text { details. }\end{array}$ & $\begin{array}{c}\text { Accurate } \\
\text { description and } \\
\text { example of food } \\
\text { chain }\end{array}$ & $\begin{array}{l}\text { Inaccurate } \\
\text { description of } \\
\text { food chain with } \\
\text { example. }\end{array}$ & $\begin{array}{c}\text { Inaccurate } \\
\text { description of } \\
\text { food chain. No } \\
\text { example. }\end{array}$ \\
\hline $\begin{array}{l}\text { Interactions of } \\
\text { organisms } \\
\text { (populations, } \\
\text { communities, } \\
\text { ecosystems) }\end{array}$ & $\begin{array}{c}\text { Accurate } \\
\text { description and } \\
\text { example of } \\
\text { population, } \\
\text { community, and } \\
\text { ecosystem with } \\
\text { supporting } \\
\text { details. }\end{array}$ & $\begin{array}{l}\text { Accurate } \\
\text { description and } \\
\text { example of } \\
\text { population, } \\
\text { community, and } \\
\text { ecosystem. }\end{array}$ & $\begin{array}{c}\text { Inaccurate } \\
\text { description of } \\
\text { population, } \\
\text { community, and } \\
\text { ecosystem with } \\
\text { example. }\end{array}$ & $\begin{array}{l}\text { Inaccurate } \\
\text { description of } \\
\text { population, } \\
\text { community, and } \\
\text { ecosystem. No } \\
\text { example. }\end{array}$ \\
\hline $\begin{array}{c}\text { Relationships } \\
\text { of organisms } \\
\text { (predation, } \\
\text { parasitism, } \\
\text { competition, } \\
\text { symbiosis) }\end{array}$ & $\begin{array}{c}\text { Accurate } \\
\text { description and } \\
\text { example of } \\
\text { relationship, } \\
\text { with supporting } \\
\text { details. }\end{array}$ & $\begin{array}{c}\text { Accurate } \\
\text { description and } \\
\text { example of } \\
\text { relationship. }\end{array}$ & $\begin{array}{l}\text { Inaccurate } \\
\text { description of } \\
\text { relationship } \\
\text { with example. }\end{array}$ & $\begin{array}{l}\text { Inaccurate } \\
\text { description of } \\
\text { relationship. No } \\
\text { example. }\end{array}$ \\
\hline $\begin{array}{l}\text { Biotic and } \\
\text { abiotic factors }\end{array}$ & $\begin{array}{c}\text { Accurate } \\
\text { description of } 5 \\
\text { abiotic factors. }\end{array}$ & $\begin{array}{c}\text { Accurate } \\
\text { description of } \\
\text { 3-4 abiotic } \\
\text { factors. }\end{array}$ & $\begin{array}{c}\text { Accurate } \\
\text { description of } \\
1-2 \text { abiotic } \\
\text { factors. }\end{array}$ & $\begin{array}{c}\text { Inaccurate } \\
\text { description of } \\
\text { abiotic factors. }\end{array}$ \\
\hline $\begin{array}{c}\text { Environmental } \\
\text { impacts of } \\
\text { organisms }\end{array}$ & $\begin{array}{l}\text { Prediction and } \\
\text { detailed } \\
\text { description of } \\
\text { possible } \\
\text { impacts on } \\
\text { ecosystem. } \\
\end{array}$ & $\begin{array}{l}\text { Prediction and } \\
\text { brief } \\
\text { description of } \\
\text { possible } \\
\text { impacts on } \\
\text { ecosystem. } \\
\end{array}$ & $\begin{array}{l}\text { Prediction of } \\
\text { possible } \\
\text { impacts on } \\
\text { ecosystem. }\end{array}$ & $\begin{array}{l}\text { Vague or } \\
\text { inaccurate } \\
\text { prediction. }\end{array}$ \\
\hline $\begin{array}{c}\text { Group } \\
\text { communicated } \\
\text { well with each } \\
\text { other to } \\
\text { complete the } \\
\text { project }\end{array}$ & $\begin{array}{l}\text { All had regular } \\
\text { input in the } \\
\text { project and } \\
\text { sharing their } \\
\text { own efforts. }\end{array}$ & $\begin{array}{l}\text { Group } \\
\text { communicated } \\
\text { efforts and } \\
\text { roles but didn't } \\
\text { share } \\
\text { information } \\
\text { with all. }\end{array}$ & $\begin{array}{c}\text { Some } \\
\text { communication } \\
\text { about individual } \\
\text { work efforts, } \\
\text { but not among } \\
\text { all. }\end{array}$ & $\begin{array}{c}\text { No } \\
\text { communication. } \\
\text { As a result, } \\
\text { missed or } \\
\text { repeated tasks. }\end{array}$ \\
\hline
\end{tabular}



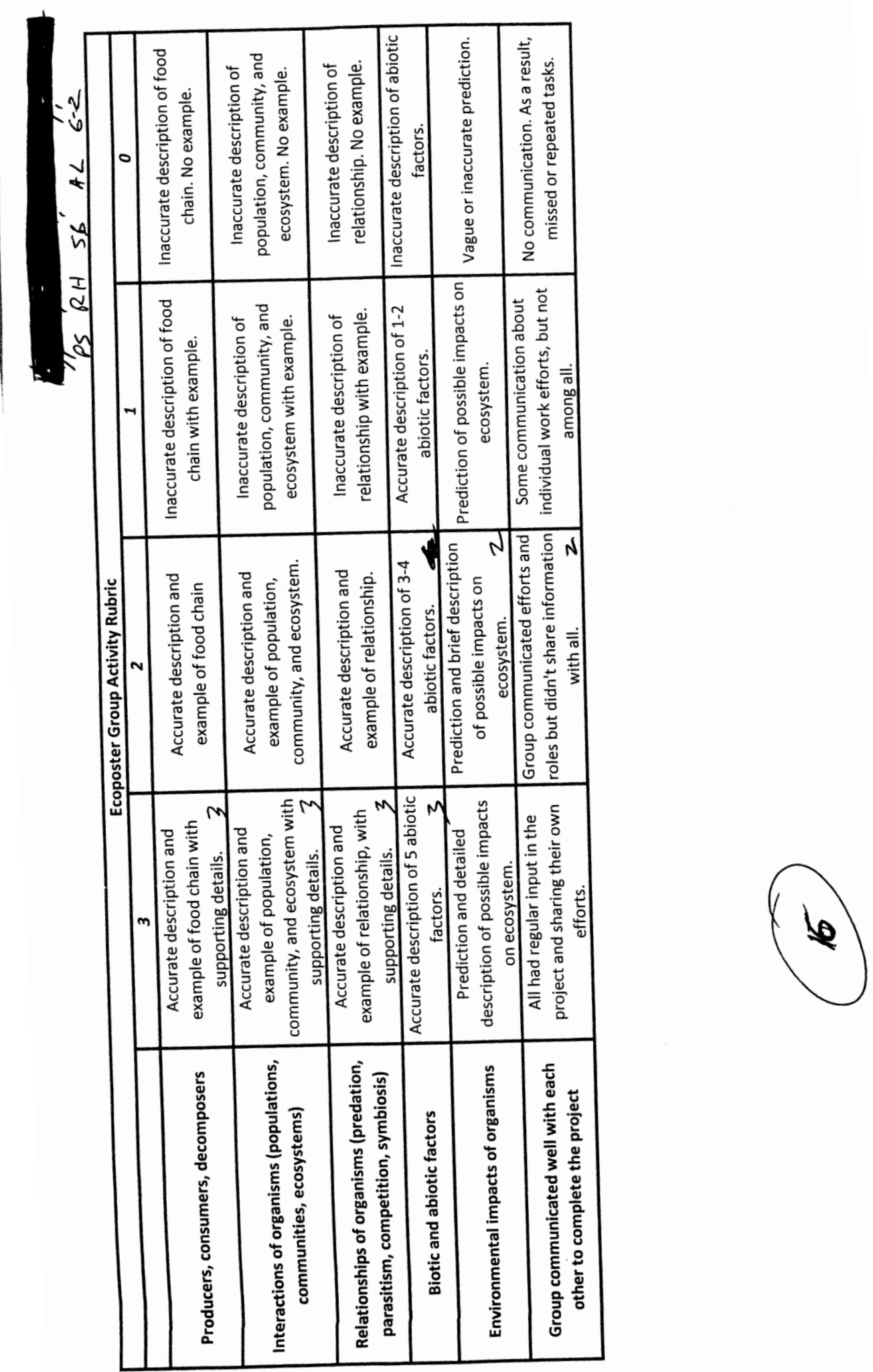


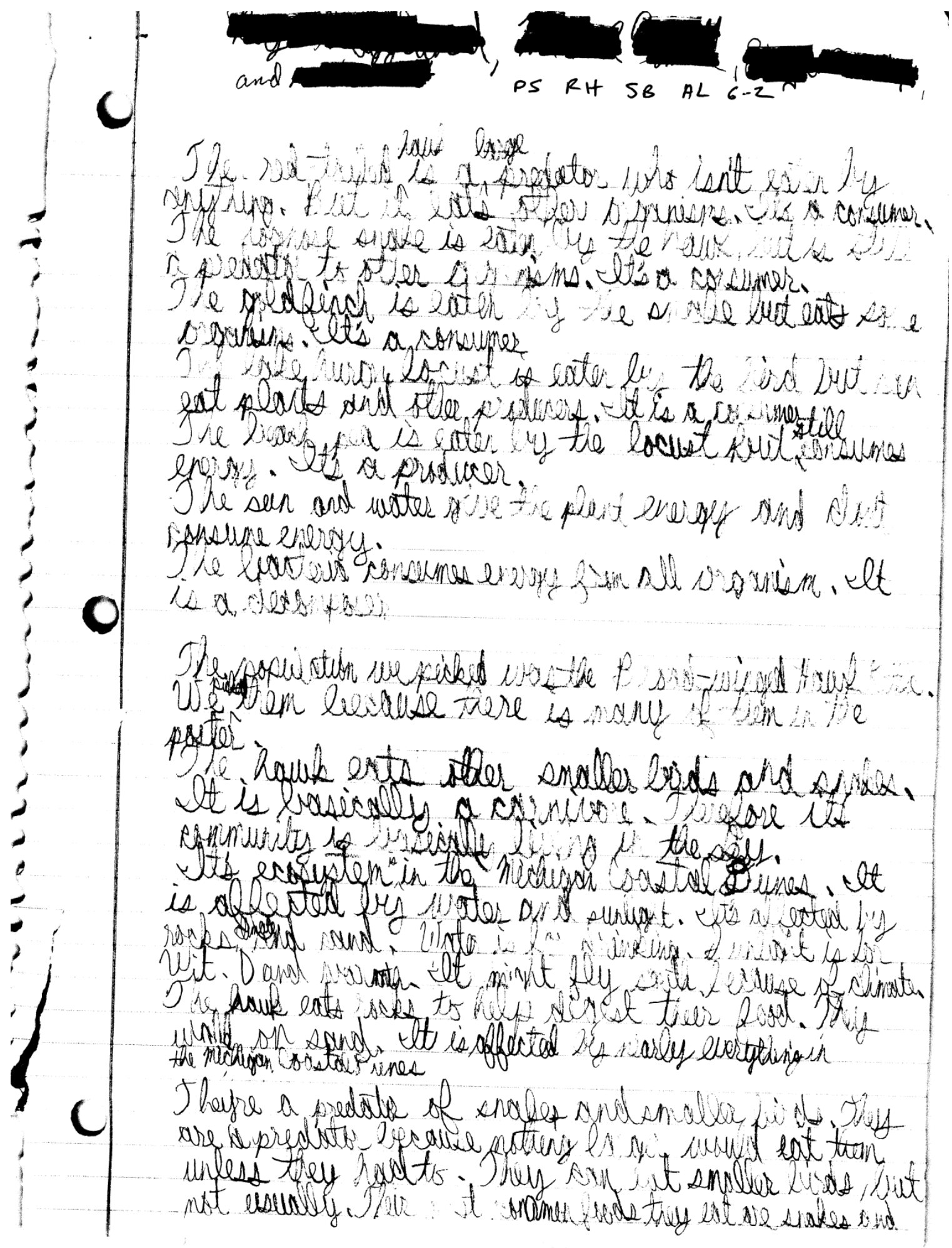




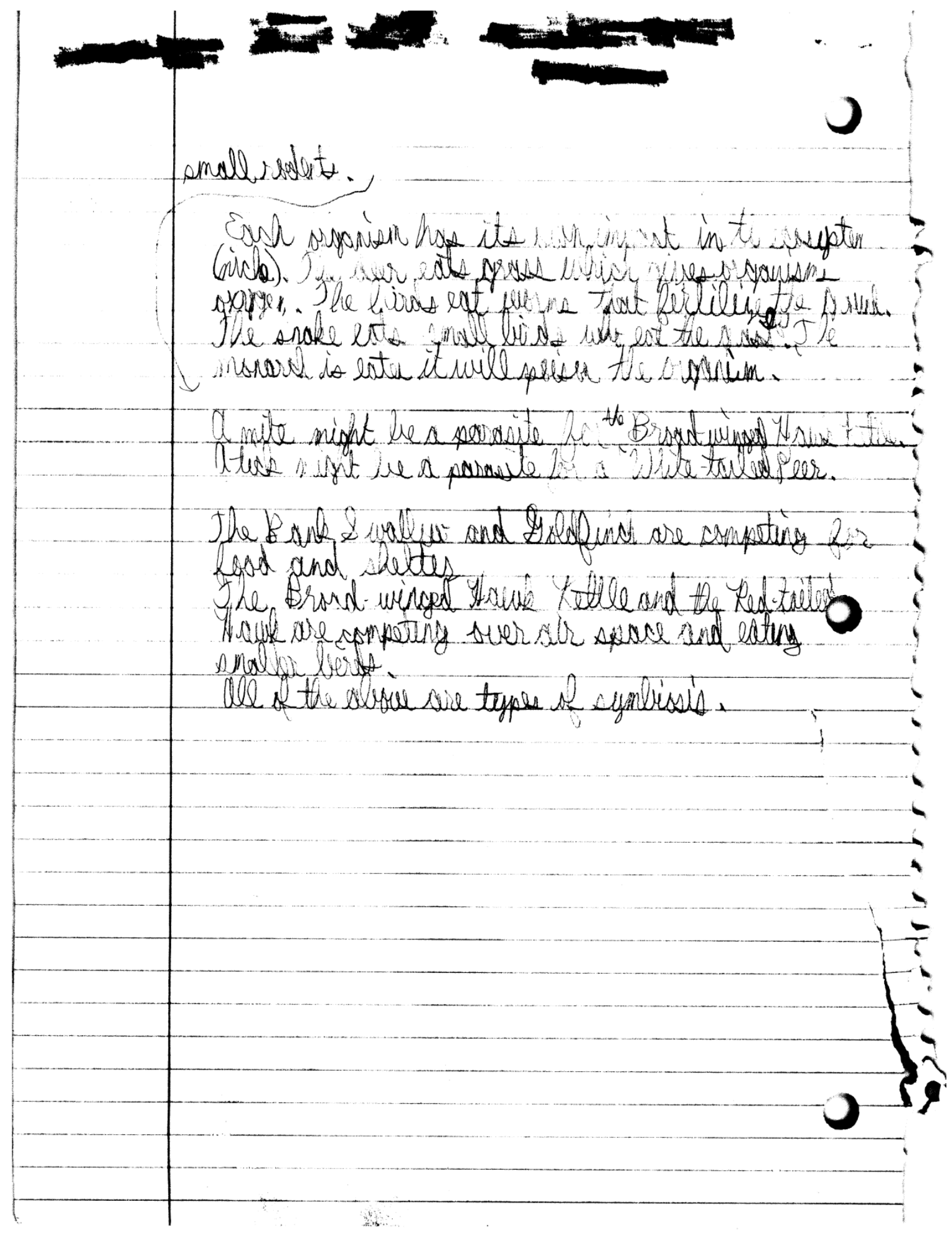




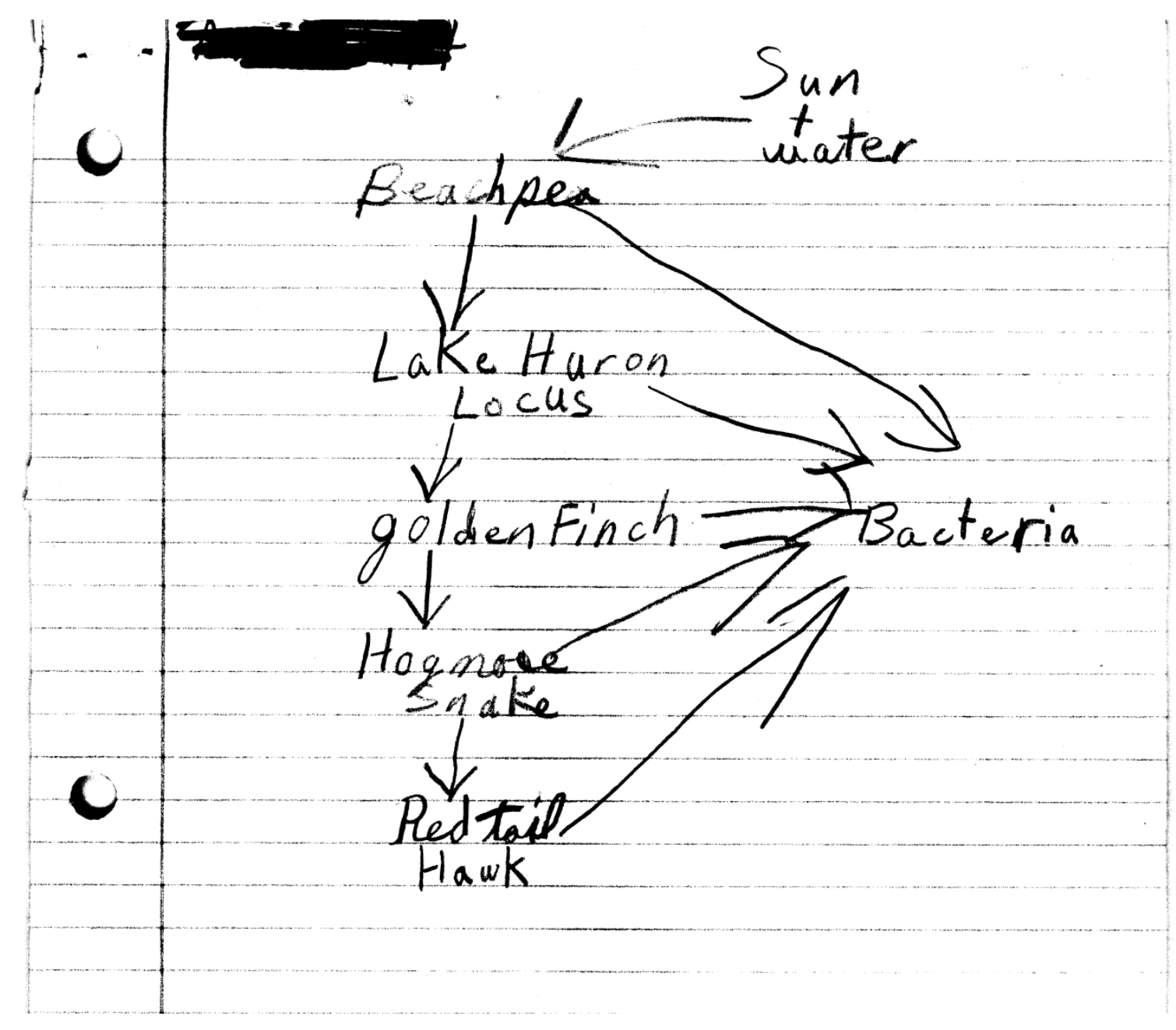

129 
This page deliberately blank 


\section{Appendix J. Pre- and Post-test Objective Questions Rubric}

\begin{tabular}{|c|c|c|c|c|c|c|}
\hline \multirow[b]{2}{*}{ Question } & \multicolumn{6}{|l|}{ Points } \\
\hline & 5 & 4 & 3 & 2 & 1 & 0 \\
\hline $\begin{array}{c}47 . \\
\text { Identify } \\
\text { four things } \\
\text { that you } \\
\text { or your } \\
\text { classmates } \\
\text { could do, } \\
\text { and } \\
\text { explain } \\
\text { how they } \\
\text { could help } \\
\text { solve } \\
\text { environme } \\
\text { ntal } \\
\text { problems. }\end{array}$ & $\begin{array}{c}\text { Four } \\
\text { reasonabl } \\
\text { e and } \\
\text { relevant } \\
\text { ideas are } \\
\text { included, } \\
\text { along with } \\
\text { detailed } \\
\text { descriptio } \\
\text { ns on how } \\
\text { idea will } \\
\text { help solve } \\
\text { environme } \\
\text { ntal } \\
\text { problems. }\end{array}$ & $\begin{array}{c}\text { Four } \\
\text { reasonabl } \\
\text { e and } \\
\text { relevant } \\
\text { ideas are } \\
\text { included, } \\
\text { along with } \\
\text { brief } \\
\text { descriptio } \\
\text { ns on how } \\
\text { idea will } \\
\text { help solve } \\
\text { environme } \\
\text { ntal } \\
\text { problems. }\end{array}$ & $\begin{array}{l}\text { Three } \\
\text { reasonabl } \\
\text { e and } \\
\text { relevant } \\
\text { ideas are } \\
\text { included, } \\
\text { along with } \\
\text { descriptio } \\
\text { ns on how } \\
\text { idea will } \\
\text { help solve } \\
\text { environme } \\
\text { ntal } \\
\text { problems. }\end{array}$ & $\begin{array}{c}\text { Two } \\
\text { reasonabl } \\
\text { e and } \\
\text { relevant } \\
\text { ideas are } \\
\text { included, } \\
\text { along with } \\
\text { descriptio } \\
\text { ns on how } \\
\text { idea will } \\
\text { help solve } \\
\text { environme } \\
\text { ntal } \\
\text { problems } \\
\text { or four } \\
\text { ideas } \\
\text { without } \\
\text { descriptio } \\
\text { n. }\end{array}$ & $\begin{array}{c}\text { One } \\
\text { reasonabl } \\
\text { e and } \\
\text { relevant } \\
\text { ideas are } \\
\text { included, } \\
\text { along with } \\
\text { descriptio } \\
\text { ns on how } \\
\text { idea will } \\
\text { help solve } \\
\text { environme } \\
\text { ntal } \\
\text { problems } \\
\text { or three } \\
\text { ideas } \\
\text { without } \\
\text { descriptio } \\
\text { n. }\end{array}$ & $\begin{array}{l}\text { Ideas are } \\
\text { neither } \\
\text { reasonabl } \\
\text { e nor } \\
\text { relevant. }\end{array}$ \\
\hline $\begin{array}{c}48 . \\
\text { Identify an } \\
\text { abiotic } \\
\text { and biotic } \\
\text { factor that } \\
\text { play a role } \\
\text { in our } \\
\text { ecosystem } \\
\text { and } \\
\text { explain the } \\
\text { influence } \\
\text { that each } \\
\text { has. }\end{array}$ & $\begin{array}{c}\text { Abiotic } \\
\text { and biotic } \\
\text { factor for } \\
\text { both } \\
\text { terrestrial } \\
\text { and } \\
\text { aquatic } \\
\text { ecosystem } \\
\text { included, } \\
\text { with } \\
\text { detailed } \\
\text { descriptio } \\
n \text { of } \\
\text { respective } \\
\text { influence. }\end{array}$ & $\begin{array}{l}\text { Abiotic } \\
\text { and biotic } \\
\text { factor for } \\
\text { both } \\
\text { terrestrial } \\
\text { and } \\
\text { aquatic } \\
\text { ecosystem } \\
\text { included, } \\
\text { with brief } \\
\text { descriptio } \\
\text { n of } \\
\text { respective } \\
\text { influence. }\end{array}$ & $\begin{array}{c}\text { Abiotic } \\
\text { and biotic } \\
\text { factor for } \\
\text { terrestrial } \\
\text { or aquatic } \\
\text { (not both) } \\
\text { ecosystem } \\
\text { included, } \\
\text { with } \\
\text { detailed } \\
\text { descriptio } \\
\text { n of } \\
\text { respective } \\
\text { influence. }\end{array}$ & $\begin{array}{c}\text { Abiotic } \\
\text { and biotic } \\
\text { factor for } \\
\text { terrestrial } \\
\text { or aquatic } \\
\text { (not both) } \\
\text { ecosystem } \\
\text { included, } \\
\text { with brief } \\
\text { descriptio } \\
n \text { of } \\
\text { respective } \\
\text { influence. }\end{array}$ & $\begin{array}{l}\text { Abiotic or } \\
\text { biotic } \\
\text { factor (not } \\
\text { both) for } \\
\text { terrestrial } \\
\text { or aquatic } \\
\text { (not both) } \\
\text { ecosystem } \\
\text { included, } \\
\text { with } \\
\text { detailed } \\
\text { descriptio } \\
n \text { of } \\
\text { respective } \\
\text { influence. }\end{array}$ & $\begin{array}{c}\text { Abiotic } \\
\text { and biotic } \\
\text { factors are } \\
\text { incorrect. }\end{array}$ \\
\hline
\end{tabular}




\begin{tabular}{|c|c|c|c|c|c|c|}
\hline $\begin{array}{c}\text { 49. Choose } \\
\text { one type } \\
\text { of } \\
\text { ecological } \\
\text { relationshi } \\
\text { p and } \\
\text { synthesize } \\
\text { two } \\
\text { imaginary } \\
\text { organisms } \\
\text { that are } \\
\text { affected } \\
\text { by it. Your } \\
\text { answer } \\
\text { should } \\
\text { include an } \\
\text { explanatio } \\
\text { nof the } \\
\text { ecological } \\
\text { relationshi } \\
\text { p and how } \\
\text { it affects } \\
\text { each of } \\
\text { the } \\
\text { "players." } \\
\text { You should } \\
\text { also } \\
\text { include a } \\
\text { drawing of } \\
\text { your } \\
\text { organisms } \\
\text { - the } \\
\text { drawing } \\
\text { should } \\
\text { label and } \\
\text { describe } \\
\text { the traits } \\
\text { that affect } \\
\text { the } \\
\text { ecological } \\
\text { relationshi } \\
\text { p. }\end{array}$ & $\begin{array}{l}\text { Ecological } \\
\text { relationshi } \\
\mathrm{p} \text { and } \\
\text { example } \\
\text { organisms } \\
\text { with } \\
\text { labeled } \\
\text { traits, } \\
\text { along with } \\
\text { a detailed } \\
\text { explanatio } \\
n \text { of } \\
\text { relationshi } \\
\mathrm{p} \text { and } \\
\text { effects are } \\
\text { included. }\end{array}$ & $\begin{array}{l}\text { Ecological } \\
\text { relationshi } \\
\mathrm{p} \text { and } \\
\text { example } \\
\text { organisms, } \\
\text { along with } \\
\text { a detailed } \\
\text { explanatio } \\
\mathrm{n} \text { of } \\
\text { relationshi } \\
\text { p or } \\
\text { effects are } \\
\text { included } \\
\text { (not both). }\end{array}$ & $\begin{array}{l}\text { Ecological } \\
\text { relationshi } \\
\text { p and } \\
\text { example } \\
\text { organisms, } \\
\text { along with } \\
\text { a brief } \\
\text { explanatio } \\
n \text { of } \\
\text { relationshi } \\
\text { p or } \\
\text { effects are } \\
\text { included } \\
\text { (not both). }\end{array}$ & $\begin{array}{c}\text { Ecological } \\
\text { relationshi } \\
\text { p and } \\
\text { example } \\
\text { organisms } \\
\text { are } \\
\text { included, } \\
\text { but } \\
\text { descriptio } \\
n \text { and } \\
\text { labels are } \\
\text { vague and } \\
\text { nondescri } \\
\text { ptive. }\end{array}$ & $\begin{array}{c}\text { Ecological } \\
\text { relationshi } \\
\mathrm{p} \text { and } \\
\text { example } \\
\text { organisms } \\
\text { are } \\
\text { included, } \\
\text { but } \\
\text { descriptio } \\
\mathrm{n} \text { and } \\
\text { labels are } \\
\text { not } \\
\text { included. }\end{array}$ & $\begin{array}{c}\text { Ecological } \\
\text { relationshi } \\
\mathrm{p} \text { is } \\
\text { incorrect. } \\
\text { Examples } \\
\text { are not } \\
\text { included, } \\
\text { or do not } \\
\text { add to } \\
\text { descriptio } \\
n .\end{array}$ \\
\hline
\end{tabular}




\section{Appendix K. Student Post-test Essays and Rubrics}

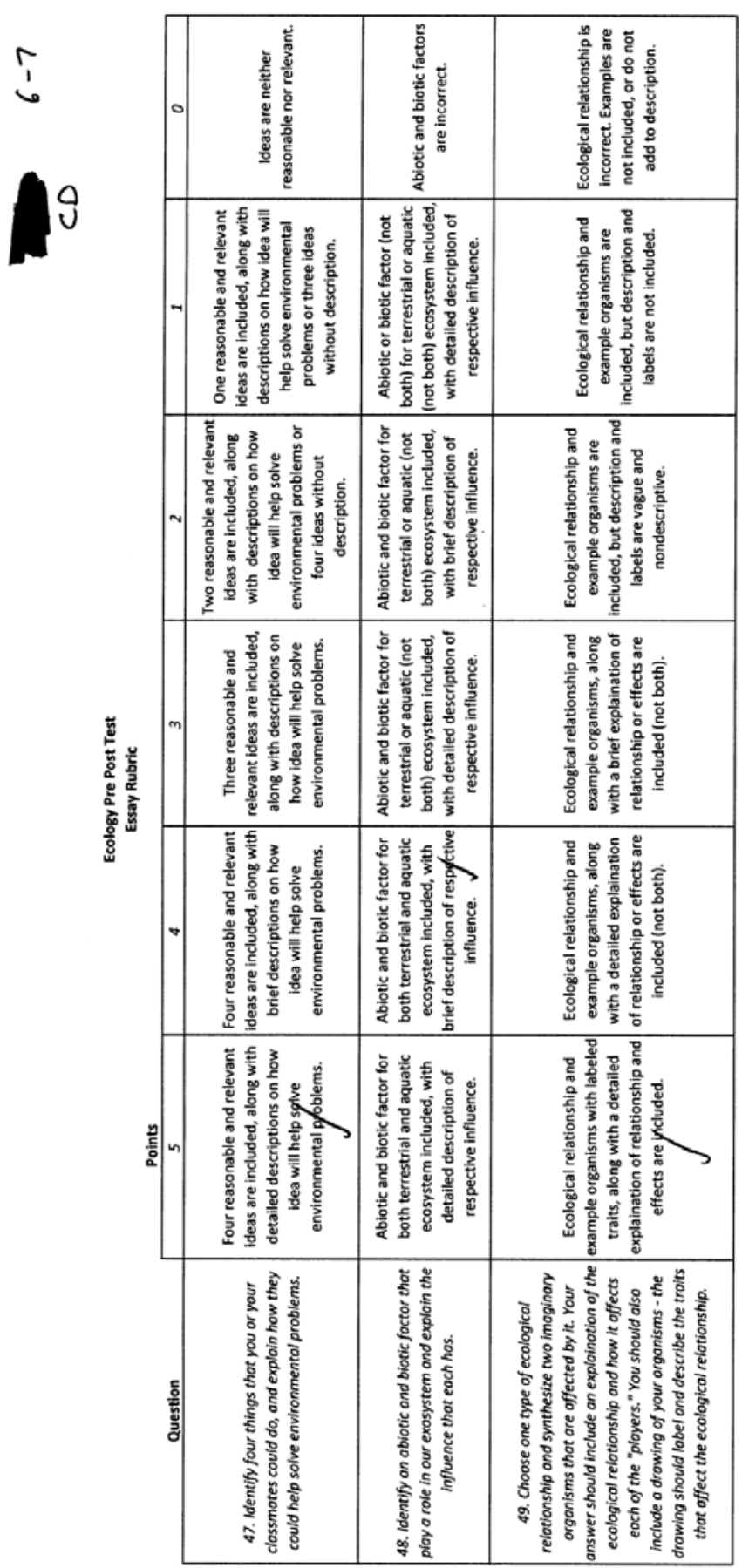


$\cos _{6-7}$

$5 / 5 / 11$

post-Test

47.1. We could ride bikes to nearby places, instead of causing pollution by getting a ride in a car.

2. We could recycle, so less garbage is dropped off at dumps.

3. We could plant trees to give off more oxygen and be homes for animals.

4. We could take shorter showers to cut down on water heating.

48. Terrestrial:

Biotic-Deer serve as a food source for wolves

Abiotic-some animals live under the soil

Aquatic

Biotic -weeds are the hide out of some fish

Abiotic-animals and alger live on stones

134 
Parasitism is when one organism benefits

3 by stealing some type of energy from the other. However the "host" is harmed by the parasite 


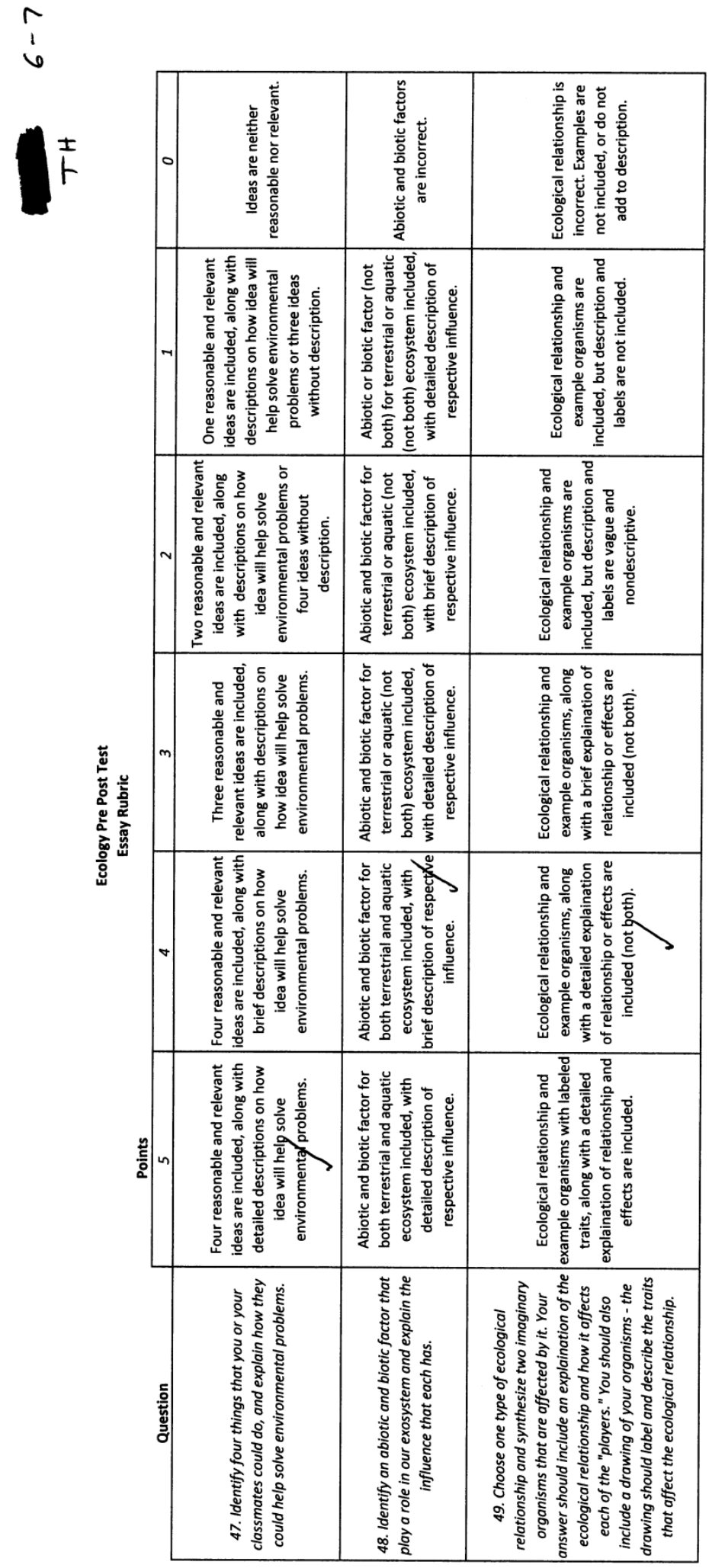

136 
Post test

TH

$6-7$

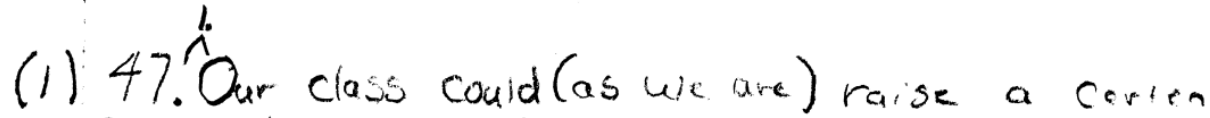
- Species + release then into the wild o that would help that species thrive $t$ options who depend- depend on it.

2. go on a feidtrip to pick up garbage that Would Clean our eniven meet (would wait not Drive.)

3. have heller school fajitas or organic Meals, that would make us healthy + would be better for the school goods a serest to us foot print.

4. turn on only one light in the classroom or unplug tearcirs compose when not in use. that would hap with our electrical bill $*$ be better on energy.

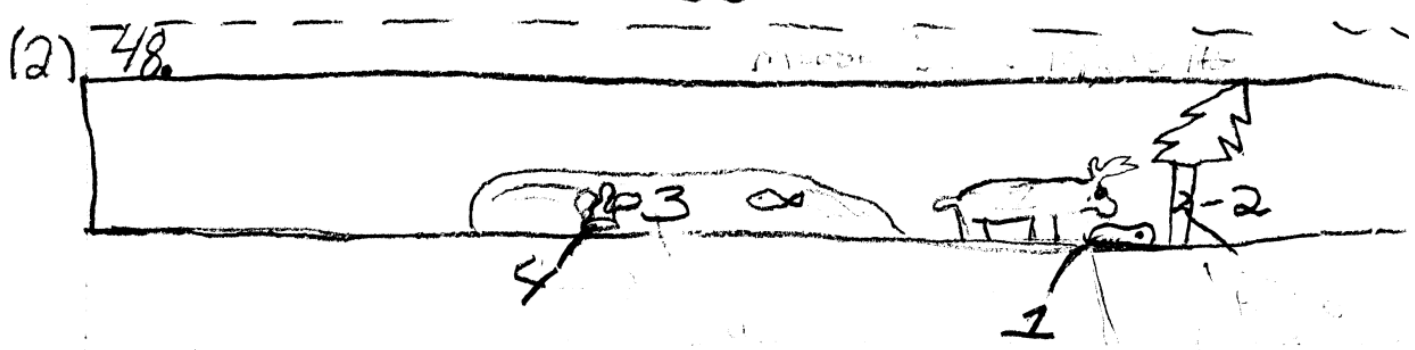

1 abiotic, stone, provide shatter for insets 2 biotic, thee, provides $\mathrm{O}_{2}+$ home $f$ leonor

3. abiotic watery shelter + drinking

4. biotic, late weed, $\mathrm{O}_{2}+$ food for animas

137 
(3): 48. parisition the paraste-Who'te lispth
$\downarrow$ Host-Small footed fastede

the fastede is being killed because the lisptin is slowly eating his trachro maning it aimost impos bie to breath. trachea of the host lispth is gutrent from the

w. lispth S. rooted Fastede

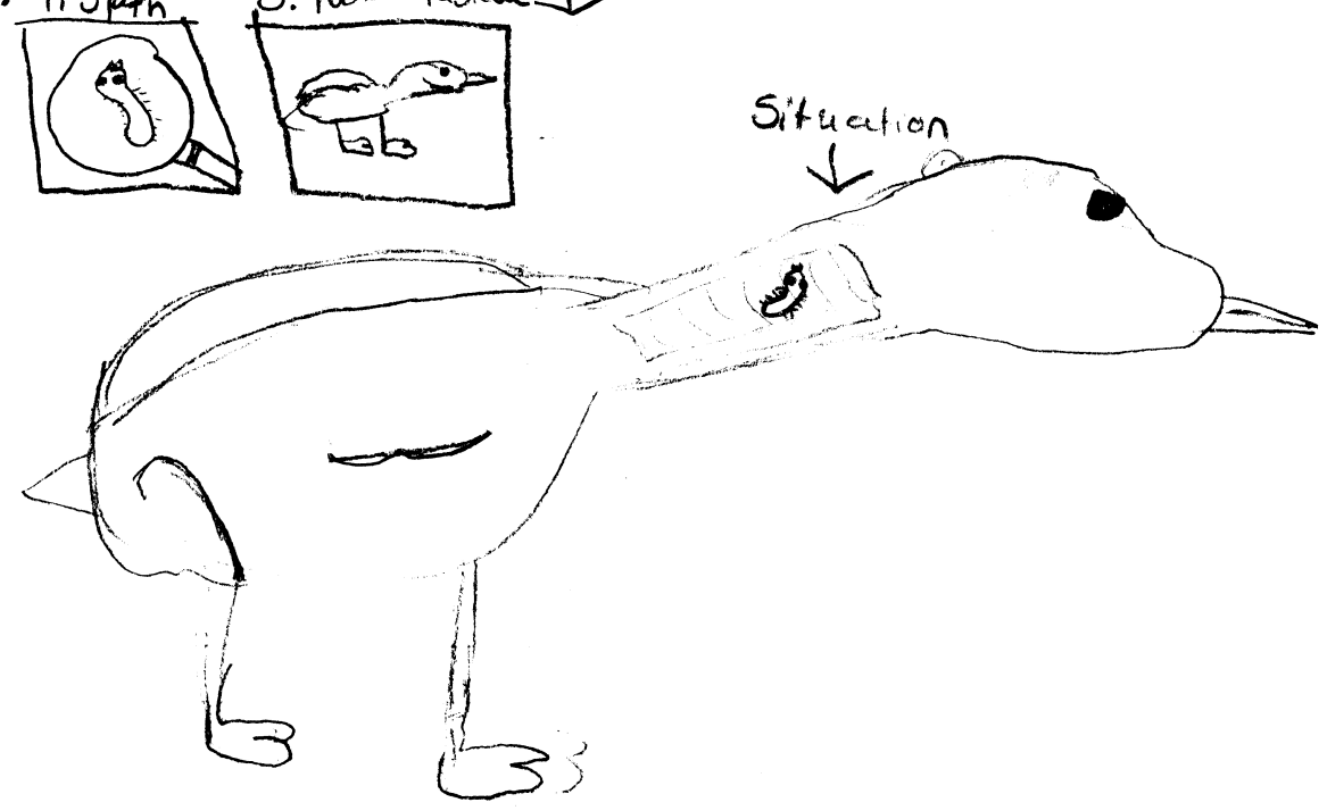

138 


\section{Appendix L. Clinical Interviews (Verbatim)}

\section{SB - Control}

\section{Clinical interview}

Logistics

Students will be interviewed individually. The student and I will be sitting opposite each other (facing each other) at a table. I will start with something in front of the student that I will ask them to read aloud, describe or tell me about.

\section{Ecology}

1. Ask the student to read aloud item \#46 (see below) from the pre/post test (in large print on a card).

46. Sustainability is described as:

a. the study of diversity in ecology.

$b$. the ability to fulfill your own personal needs, without regards to the overall human population and its future.

c. giving up all material belongings.

$d$. the ability to fulfill human needs in a way that allows the human population to survive indefinitely.

a. Ask student the following questions:

i. What would you choose as the correct answer?

1. Why?

"Umm...A. Well I kinda (sic) of just guessed on what looked the best or sounded the best."

ii. Why didn't you choose $b$ (if student chose d)?

"Umm...well it doesn't say it's studying anything, it just saying something of what it is not."

iii. Why didn't you choose $c$ ?

"Well cause you wouldn't have to give up everything...like I don't know, like showers or something like that. You would want to keep that, or like clothes or something."

iv. Why didn't you choose $d$ ?

"Well, it kinda (sic) of seemed like the same thing as b, so yeah, it didn't seem like it to me."

v. What does "sustainability" mean to you?

1. Can you give me an example?

"Umm...like...I don't know. I can't think of anything.

vi. What does "ecology" mean to you?

1. Can you give me an example?

"I don't know, it kinda (sic) of reminds me of ecosystems I guess. Because the "eco" in ecology. When I look at the word I guess it just makes me think of Earth I guess or woods by a lake or something."

vii. What does "diversity" mean to you? 
1. Can you give me an example?

"Umm well it kinda (sic) of reminds me of like changing I guess. Like well like when someone kinda (sic) of changes their attitude or something like...if their sad and them someone cheers them up and then their good."

viii. What does "population" mean to you?

1. Can you give me an example?

"Well, the amount of one species in an area. All the People in Crystal Falls."

2. Ask the student to read aloud item \#11 (see below) from the pre/post test (in large print on a card).

11. An ecosystem consists of

a. a community of organisms.

b. energy.

c. the soil, water, and weather.

d. all of the above.

a. Ask student the following questions:

i. What would you choose as the correct answer?

1. Why?

"D. Because an ecosystem does consist of all that stuff, because an ecosystem is like um the abiotic and biotic stuff."

ii. Why didn't you choose a (if student chose $d$ )?

"The other ones had stuff from an ecosystem too."

iii. Why didn't you choose $b$ ?

"It's all important for an ecosystem."

iv. Why didn't you choose $c$ ?

"It's all important for an ecosystem."

v. What does "ecosystem" mean to you?

1. Can you give me an example?

"Like life I guess...and like everything in it. A bird in a forest."

vi. What does "community" mean to you?

1. Can you give me an example?

"It's a like all the living things in an ecosystem....all the biotic things. All the animals and plants of an area and people."

vii. What does "biotic and abiotic" mean to you?

1. Can you give me an example?

"Living is biotic and non-living is abiotic. Living...a person, and nonliving...water."

3. Provide student with six words (osprey, trout, minnow, caddisfly, phytoplankton, algae, crayfish) related to food chain (written in big letters on separate 1" $\times 2$ " slips of paper).

a. Ask student to arrange the words on a piece of paper and draw lines to show words that are related.

algae $\rightarrow$ caddisfly $\rightarrow$ phytoplankton $\rightarrow$ crayfish $\rightarrow$ minnow $\rightarrow$ trout $\rightarrow$ osprey

b. Ask the following questions:

i. What does "food chain" mean to you? 
"Umm...like how energy is moved from organism to another. The transfer of energy."

ii. What does "energy transfer" mean to you?

1. Can you give me an example from your arrangement of the words?

"How energy is kinda (sic) of like put in another state of energy. Trout is putting energy to the osprey from it eating it and its gaining more energy to move around and switching energy from moving around."

iii. What does "producer" mean to you?

1. Can you give me an example? "Like something that makes it own food or produces its own food. Like a plant."

iv. What does "consumer" mean to you?

1. Can you give me an example? "Something or something that has to eat, has to get their own food and eat it. A person."

v. What does "decomposer" mean to you?

1. Can you give me an example? "Like something that breaks food down, it doesn't exactly eat it, but it just kinda (sic) of breaks it down. A fungus."

vi. What does "competition" mean to you?

1. Can you give me an example?

"When two living things like are like competing over food or shelter any needed thing. A wolf and coyote fight over deer for food."

vii. What does "parasitism" mean to you?

1. Can you give me an example?

“Umm...it's when the...I don't know...but the parasite I guess is feeding off the host but it doesn't kill it right away, like a tick sucking a human's blood or a dog."

viii. What does "symbiosis" mean to you?

1. Can you give me an example?

"Umm...I don't know that one. Is it like when the sun goes to plant, and the plant goes to the...is it kinda (sic) like a food chain? I don't know, that's just a random guess."

ix. What does "predator/prey" mean to you?

1. Can you give me an example?

"Umm, while like where the predator is...it's like the predator is eating the prey for food. A wolf is eating a deer." 


\section{RT - Experimental}

Clinical interview

\section{Logistics}

Students will be interviewed individually. The student and I will be sitting opposite each other (facing each other) at a table. I will start with something in front of the student that I will ask them to read aloud, describe or tell me about.

\section{Ecology}

1. Ask the student to read aloud item \#46 (see below) from the pre/post test (in large print on a card).

46. Sustainability is described as:

a. the study of diversity in ecology.

b. the ability to fulfill your own personal needs, without regards to the overall human population and its future.

c. giving up all material belongings.

d. the ability to fulfill human needs in a way that allows the human population to survive indefinitely.

a. Ask student the following questions:

i. What would you choose as the correct answer?

1. Why?

"D. Cause it makes the most sense."

ii. Why didn't you choose a (if student chose d)?

"Because it doesn't make sense."

iii. Why didn't you choose b?

"It doesn't make sense. How it says without regard to the overall human population."

iv. Why didn't you choose $c$ ?

"Because sustainability isn't giving up all material belongings."

v. What does "sustainability" mean to you?

1. Can you give me an example?

"You're not like using all the resources just because you want to."

vi. What does "ecology" mean to you?

1. Can you give me an example?

"I don't know."

vii. What does "diversity" mean to you?

1. Can you give me an example?

"Living."

viii. What does "population" mean to you?

1. Can you give me an example?

"One or more people or organisms. It's all in one place at the same time."

2. Ask the student to read aloud item \#11 (see below) from the pre/post test (in large print on a card).

11. An ecosystem consists of 

a. a community of organisms.
b. energy.
c. the soil, water, and weather.
d. all of the above.

a. Ask student the following questions:

i. What would you choose as the correct answer?

1. Why?

"D. Cause an ecosystem an ecosystem consists of a community of organisms, energy, soil, water, and weather. All are important."

ii. Why didn't you choose a (if student chose d)?

"All are important."

iii. Why didn't you choose $b$ ?

"All are important."

iv. Why didn't you choose $c$ ?

"All are important."

v. What does "ecosystem" mean to you?

1. Can you give me an example?

"Like...something or somewhere where someone lives. A jackpine ecosystem from the poster we looked at."

vi. What does "community" mean to you?

1. Can you give me an example?

"Various numbers of organisms living."

vii. What does "biotic and abiotic" mean to you?

1. Can you give me an example?

"Biotic is non-living organisms, like a rock. Abiotic is living organisms, like a human."

3. Provide student with six words (osprey, trout, minnow, caddisfly, phytoplankton, algae, crayfish) related to food chain (written in big letters on separate 1" 1 2" slips of paper).

a. Ask student to arrange the words on a piece of paper and draw lines to show words that are related.

algae $\rightarrow$ osprey $\rightarrow$ caddisfly $\rightarrow$ minnow $\rightarrow$ crayfish $\rightarrow$ trout $\rightarrow$ phytoplankton

b. Ask the following questions:

i. What does "food chain" mean to you?

"Organisms getting energy from other organisms."

ii. What does "energy transfer" mean to you?

1. Can you give me an example from your arrangement of the words?

"An organisms getting its energy from a different organism. Like a osprey eating the algae."

iii. What does "producer" mean to you?

1. Can you give me an example?

"An organism that makes its own energy. Plant."

iv. What does "consumer" mean to you?

1. Can you give me an example? 
"An organism getting its energy from eating something else. An owl eating a mouse."

v. What does "decomposer" mean to you?

1. Can you give me an example?

"Something that breaks down other organisms. Fungus."

vi. What does "competition" mean to you?

1. Can you give me an example?

"When two organisms are competing against

something...fighting. A Giraffe and zebra over food and water."

vii. What does "parasitism" mean to you?

1. Can you give me an example?

"An organism gets its energy from another organism, but doesn't kill them. A tick on a dog."

viii. What does "symbiosis" mean to you?

1. Can you give me an example?

"I don't know."

ix. What does "predator/prey" mean to you?

1. Can you give me an example?

"When an organisms tries to get its energy from another

organisms by like hunting it down. Like a wolf and a rabbit. The rabbit is the prey and the wolf is the predator." 


\section{NZ - Control \\ Clinical interview}

Logistics

Students will be interviewed individually. The student and I will be sitting opposite each other (facing each other) at a table. I will start with something in front of the student that I will ask them to read aloud, describe or tell me about.

\section{Ecology}

1. Ask the student to read aloud item \#46 (see below) from the pre/post test (in large print on a card).

46. Sustainability is described as:

a. the study of diversity in ecology.

b. the ability to fulfill your own personal needs, without regards to the overall human population and its future.

c. giving up all material belongings.

d. the ability to fulfill human needs in a way that allows the human population to survive indefinitely.

a. Ask student the following questions:

i. What would you choose as the correct answer?

1. Why? "B (Rereads b) Sustain means to like keep what you only need. Ability is the ability to do that."

ii. Why didn't you choose a (if student chose $d$ )? "Diversity, I think doesn't have to do with it."

iii. Why didn't you choose $c$ ?

"Because that that has nothing to do really with ecology, except maybe for saving energy."

iv. Why didn't you choose $d$ ?

"That one I had a little bit (read again). Well I thought it was wrong in the end, because like...it wasn't really specific enough."

v. What does "sustainability" mean to you?

1. Can you give me an example?

"To like fulfill something, the ability to sustain something. Maybe, but not likely."

vi. What does "ecology" mean to you?

1. Can you give me an example?

"It is the study of Earth. More like the study of plants on Earth...living organisms. Grass, plants."

vii. What does "diversity" mean to you?

1. Can you give me an example? "I didn't even know there was diversity in ecology, but I know diversity from a social studies meaning...to have more than one crop or something." (Me: Is a crop living?; NZ: Yes; Me: Is that ecology?; NZ: Yes, it is. 
viii. What does "population" mean to you?

1. Can you give me an example?

"Numbers of organisms in a group. Pack of wolves."

2. Ask the student to read aloud item \#11 (see below) from the pre/post test (in large print on a card).

11. An ecosystem consists of

a. a community of organisms.

b. energy.

c. the soil, water, and weather.

d. all of the above.

a. Ask student the following questions:

i. What would you choose as the correct answer?

1. Why?

"D. Well because you need something to make the ecosystem. You can't just have nothing there. And energy you need, well you need like sunlight and stuff to make the plants grow. And you need the soil, water, and weather for the plants and everything else. That's why I chose d. We need everything."

ii. Why didn't you choose $a$ (if student chose $d$ )?

"We need everything."

iii. Why didn't you choose $b$ ?

"We need everything."

iv. Why didn't you choose $c$ ?

"We need everything."

v. What does "ecosystem" mean to you?

1. Can you give me an example?

"An ecosystem is like a whole big place where all different creatures live. A river: there's tons of fish and algae and plankton."

vi. What does "community" mean to you?

1. Can you give me an example?

"A community is like a habitat with population inside of it. Rabbits in a burrow. Ants, because you can have tons in the ground."

vii. What does "biotic and abiotic" mean to you?

1. Can you give me an example?

"Biotic means anything living. Abiotic means nothing that is like alive, at all. Biotic would be you and me, trees, plants. And abiotic would be rocks, soil, weather, and temperature."

3. Provide student with six words (osprey, trout, minnow, caddisfly, phytoplankton, algae, crayfish) related to food chain (written in big letters on separate 1 " $\times 2$ " slips of paper).

a. Ask student to arrange the words on a piece of paper and draw lines to show words that are related.

algae $\rightarrow$ phytoplankton $\rightarrow$ caddisfly $\rightarrow$ crayfish $\rightarrow$ minnow $\rightarrow$ trout $\rightarrow$ osprey

b. Ask the following questions:

i. What does "food chain" mean to you? 
"The order of food. $10 \%$ of the energy gets passed on to the next level."

ii. What does "energy transfer" mean to you?

1. Can you give me an example from your arrangement of the words?

"Kinda (sic) of like going from one organism to another. The trout gives it energy to its offspring when it's born."

iii. What does "producer" mean to you?

1. Can you give me an example?

"A producers is like plants. Rosebushes."

iv. What does "consumer" mean to you?

1. Can you give me an example?

"A consumer is something that eats either a producer or another consumer. The trout because it would eat the minnow."

v. What does "decomposer" mean to you?

1. Can you give me an example?

"Something that breaks down something else when it's dead.

Fungus or termites."

vi. What does "competition" mean to you?

1. Can you give me an example?

"Well what I think competition is one organism trying to get something while another organism trying to get the same thing. Giraffe and zebra."

vii. What does "parasitism" mean to you?

1. Can you give me an example?

"Where a parasite starts sucking your blood. And that'd be like a tick or a tapeworm."

viii. What does "symbiosis" mean to you?

1. Can you give me an example?

"Well I know this is photosynthesis, but symbiosis kinda (sic) of makes me feel like plants producing energy. An example would be plants taking the sunlight."

ix. What does "predator/prey" mean to you?

1. Can you give me an example?

"Prey is something that tries not to be eaten while the predator is something that is going to eat it. A cat and a mouse." 


\section{JT - Experimental \\ Clinical interview}

Logistics

Students will be interviewed individually. The student and I will be sitting opposite each other (facing each other) at a table. I will start with something in front of the student that I will ask them to read aloud, describe or tell me about.

\section{Ecology}

1. Ask the student to read aloud item \#46 (see below) from the pre/post test (in large print on a card).

46. Sustainability is described as:

a. the study of diversity in ecology.

b. the ability to fulfill your own personal needs, without regards to the overall human population and its future.

c. giving up all material belongings.

d. the ability to fulfill human needs in a way that allows the human population to survive indefinitely.

a. Ask student the following questions:

i. What would you choose as the correct answer?

1. Why?

"I would pick B, the ability to fulfill your own personal needs, without regards to the overall human population and its future. I would pick it because it's like the ability to fulfill your future without harming things."

ii. Why didn't you choose $a$ (if student chose $d$ )?

"I didn't think that would really fit because it's not like how to fill it or sustain it."

iii. Why didn't you choose $c$ ?

"Because you really wouldn't have to give up all your material belongings. You could like easy just pulling out something to save electricity. You wouldn't have to give up every material belonging away."

iv. Why didn't you choose $d$ ?

"I didn't pick D because I don't think the human population will survive indefinitely, it will survive, but I don't think it will survive forever."

v. What does "sustainability" mean to you?

1. Can you give me an example?

"Sustainability to me means like how to fulfill your own personal needs and goals. Like if you make a house, you try to find and if you took away animal's homes, try to find them a new home the best you can because you shouldn't take their own homes away."

vi. What does "ecology" mean to you?

1. Can you give me an example? 
"Ecology means like the study of living and nonliving organisms. Soil, plants."

vii. What does "diversity" mean to you?

1. Can you give me an example?

"To me, diversity means not to get rid of things.

Habitats...animal habitats."

viii. What does "population" mean to you?

1. Can you give me an example?

"Population is like a how many animals are in a group. Like say deer and how many there are in the group."

2. Ask the student to read aloud item \#11 (see below) from the pre/post test (in large print on a card).

11. An ecosystem consists of

a. a community of organisms.

b. energy.

c. the soil, water, and weather.

d. all of the above.

a. Ask student the following questions:

i. What would you choose as the correct answer?

1. Why?

"I would pick D. I would pick D because you need a community

of organisms, you need energy, you need soil, water, and

weather, because without soil, water, or weather, the

organisms couldn't survive.

ii. Why didn't you choose a (if student chose d)?

"Without a community of organisms, you wouldn't really have

anything to eat, and couldn't survive."

iii. Why didn't you choose $b$ ?

"Energy fits in like because the plants produce their own energy and if they grow bigger and bigger, deer and moose can eat them so that way they can survive on their own."

iv. Why didn't you choose $c$ ?

"We need these to survive."

v. What does "ecosystem" mean to you?

1. Can you give me an example?

"Ecosystem means like the organisms that are nonliving and living. Nonliving would be rocks. Living organisms would be humans."

vi. What does "community" mean to you?

1. Can you give me an example?

"Like we have our own community of people or something, and the deer or wolf have their own communities of families. Deer, wolves, humans, moose, rabbits, coyotes. It's like their own group.

vii. What does "biotic and abiotic" mean to you?

1. Can you give me an example? 
"Abiotic is the non...once-living and organisms...No, biotic would mean the study of living organisms and once-living, abiotic would be non-living organisms; For biotic I would say coyotes. And for nonliving, or for abiotic I would say soil."

3. Provide student with six words (osprey, trout, minnow, caddisfly, phytoplankton, algae, crayfish) related to food chain (written in big letters on separate 1 " $\times 2$ " slips of paper).

a. Ask student to arrange the words on a piece of paper and draw lines to show words that are related.

algae $\rightarrow$ phytoplankton $\rightarrow$ caddisfly $\rightarrow$ crayfish $\rightarrow$ minnow $\rightarrow$ trout $\rightarrow$ osprey

b. Ask the following questions:

i. What does "food chain" mean to you?

"A food chain is like how organisms in their own number in line how they would get their food... who they would eat from.

Where they get their food and who they'd eat."

ii. What does "energy transfer" mean to you?

1. Can you give me an example from your arrangement of the words?

"Energy transfer is how someone or something would get its energy. Like an osprey would get its energy from the trout."

iii. What does "producer" mean to you?

1. Can you give me an example?

"Something that like produce their own energy. Dandelion."

iv. What does "consumer" mean to you?

1. Can you give me an example?

"Something that consumes another organism. I would say a crow or an eagle eating something along the side of the road.

Or a trout eating a minnow."

v. What does "decomposer" mean to you?

1. Can you give me an example?

"Something that can decompose something...break an organism down after its dead. Algae."

vi. What does "competition" mean to you?

1. Can you give me an example?

"Like when some organism or something is like competing for something to eat, something that they want, they'll compete to see who can get it first. Maybe moose and deer trying to eat the same plants or grass."

vii. What does "parasitism" mean to you?

1. Can you give me an example?

"A parasite means to me is like an organism that won't kill its prey right way, it will keep it lasting, it will keep it alive for a while so that it can live off it longer. A tick on a human being, a dog, any living organism."

viii. What does "symbiosis" mean to you?

1. Can you give me an example? 
"Symbiosis means to me how the animals will react with each other in their relationships. Minnows with other minnows, I would say."

ix. What does "predator/prey" mean to you?

1. Can you give me an example?

"Predator-prey means to me is like the predator will eat it's...will fight to eat something. So like a wolf trying to eat a moose or a pack of wolves trying to eat a moose. The moose would be the prey and the wolves would be the predator." 


\section{BV - Control}

\section{Clinical interview}

\section{Logistics}

Students will be interviewed individually. The student and I will be sitting opposite each other (facing each other) at a table. I will start with something in front of the student that I will ask them to read aloud, describe or tell me about.

\section{Ecology}

1. Ask the student to read aloud item \#46 (see below) from the pre/post test (in large print on a card).

46. Sustainability is described as:

a. the study of diversity in ecology.

b. the ability to fulfill your own personal needs, without regards to the overall human population and its future.

c. giving up all material belongings.

d. the ability to fulfill human needs in a way that allows the human population to survive indefinitely.

a. Ask student the following questions:

i. What would you choose as the correct answer?

1. Why?

"B. Because for sustainability, I remember writing notes on this. It's like what it needed and what it was without in a population."

ii. Why didn't you choose a (if student chose d)?

"I just remember when we took notes, I couldn't really place it, I think $b$ was the best answer for me."

iii. Why didn't you choose $c$ ?

"I'm not really sure."

iv. Why didn't you choose $d$ ?

"Actually, I wasn't sure to pick between b and d, because they're kinda (sic) of...to me they both have like their needs in a way that allows them for the population of them."

v. What does "sustainability" mean to you?

1. Can you give me an example? "Sustainability to me means like...I really can't describe it."

vi. What does "ecology" mean to you?

1. Can you give me an example? "Where we were looking at the posters with all of the animals on them."

vii. What does "diversity" mean to you?

1. Can you give me an example? "I can't think of anything."

viii. What does "population" mean to you?

1. Can you give me an example? 
"Like the population of our classroom. Like how many students are in the classroom."

2. Ask the student to read aloud item \#11 (see below) from the pre/post test (in large print on a card).

11. An ecosystem consists of

a. a community of organisms.

b. energy.

c. the soil, water, and weather.

d. all of the above.

a. Ask student the following questions:

i. What would you choose as the correct answer?

1. Why?

"I would pick $d$. Because the ecosystem contains a community of organisms, they need energy to live and they lose energy, and things that surround them are the soil, water, and weather. And that's why I picked d."

ii. Why didn't you choose a (if student chose d)?

"Because I was like...because they also have energy, soil, and water."

iii. Why didn't you choose $b$ ?

"They all need each other."

iv. Why didn't you choose $c$ ?

"They all need each other."

v. What does "ecosystem" mean to you?

1. Can you give me an example?

"Like again, like the poster. A community of it. In the woods."

vi. What does "community" mean to you?

1. Can you give me an example?

"Like one place, a certain place in the woods, like a big area."

vii. What does "biotic and abiotic" mean to you?

1. Can you give me an example?

"Biotic means living and abiotic means non-living. Fungi for abiotic and for biotic...any type of fish."

3. Provide student with six words (osprey, trout, minnow, caddisfly, phytoplankton, algae, crayfish) related to food chain (written in big letters on separate 1 " $\times 2$ " slips of paper).

a. Ask student to arrange the words on a piece of paper and draw lines to show words that are related.

algae $\rightarrow$ caddisfly $\rightarrow$ crayfish $\rightarrow$ phytoplankton $\rightarrow$ minnow $\rightarrow$ trout $\rightarrow$ osprey

b. Ask the following questions:

i. What does "food chain" mean to you?

"The ways that it lives, and how what the ecosystem...like how it is living."

ii. What does "energy transfer" mean to you?

1. Can you give me an example from your arrangement of the words?

"Energy transfer from point a to point b. A coyote and a deer." 
iii. What does "producer" mean to you?

1. Can you give me an example?

"Something that like produces...that doesn't sometimes need energy, but not as much as others and produces their own energy. I can't think of an example."

iv. What does "consumer" mean to you?

1. Can you give me an example?

"A consumer has to gets its energy from something. A deer and leaves and trees. The deer is getting energy from the leaves and trees."

v. What does "decomposer" mean to you?

1. Can you give me an example?

"A decomposer means something that is breaking down into the ground. I can't think of an example."

vi. What does "competition" mean to you?

1. Can you give me an example?

"Competing...against each other. Two fish competing against each other for food."

vii. What does "parasitism" mean to you?

1. Can you give me an example?

"I can't think of something."

viii. What does "symbiosis" mean to you?

1. Can you give me an example?

"I can't think of anything."

ix. What does "predator/prey" mean to you?

1. Can you give me an example?

"Umm...it means the predator and the prey...there against each other. And the prey is the predator's food. Like I said at the beginning, a coyote chasing a deer." 


\section{JJ - Experimental \\ Clinical interview}

Logistics

Students will be interviewed individually. The student and I will be sitting opposite each other (facing each other) at a table. I will start with something in front of the student that I will ask them to read aloud, describe or tell me about.

\section{Ecology}

1. Ask the student to read aloud item \#46 (see below) from the pre/post test (in large print on a card).

46. Sustainability is described as:

a. the study of diversity in ecology.

b. the ability to fulfill your own personal needs, without regards to the overall human population and its future.

c. giving up all material belongings.

d. the ability to fulfill human needs in a way that allows the human population to survive indefinitely.

a. Ask student the following questions:

i. What would you choose as the correct answer?

1. Why? "I would choose $d$ as the correct answer. Well, when we were doing it like in our journal, I kind of like have it all in my mind, I just remember it real easily because you teached it real well."

ii. Why didn't you choose a (if student chose d)?

"The study of diversity in ecology, l'd say...well diversity is different things, like a lot of different things, kind of like the rainforest. It's just like the study of it, I don't really think that would be needed to survive."

iii. Why didn't you choose $b$ ?

(Reads again). "Well when it says future, that's when I thought...I crossed it out, because I'm like talking like right now...in a way."

iv. Why didn't you choose $c$ ?

"We don't really need to do that at all. I mean of course if a light bulb goes out, then I mean, that's something. But I mean, you don't really need to throw out anything you don't need to."

v. What does "sustainability" mean to you?

1. Can you give me an example?

"To sustain something. Kind of like to do something in your way. Kinda (sic) of allows the human race to kind go on. Kind of like garbage pickup, because I know sometimes there is garbage in the ocean, maybe sometimes, so maybe we can like stop that."

vi. What does "ecology" mean to you?

1. Can you give me an example? 
"Ecology to me, it's kind of like, I would say that it's kind of like a forest to me; like it's the study of the whole earth, but like on land but not really on water...it just kind of talks about land."

vii. What does "diversity" mean to you?

1. Can you give me an example?

"It's kind of like mixed up, kind of like the Temperate Mixed

Forest here in the UP...it's not just one thing, it's also another...of different trees."

viii. What does "population" mean to you?

1. Can you give me an example?

"Like in a square mile, like how much people are in that square mile, and say if the world...well it's kind of like the footprint I

did...if everyone lived like me it would take 4.99 Earths to support me. It's like the human population."

2. Ask the student to read aloud item \#11 (see below) from the pre/post test (in large print on a card).

11. An ecosystem consists of
a. a community of organisms.
b. energy.
c. the soil, water, and weather.
d. all of the above.

a. Ask student the following questions:

i. What would you choose as the correct answer?

1. Why?

"I would choose also d. A, b, and c....well b is kinda (sic) of like energy and water, food and everything that there needs to be is good like energy to eat and drink and all that. $A$ is a good one because there's different types of organisms, like different animals there living. And the soil, water, and weather...I would have to say yes, but maybe the soil...that would still be good for the plants to grow so that would kind of go into energy...and the weather though I mean that helps to. So there all important."

ii. Why didn't you choose a (if student chose d)?

iii. Why didn't you choose $b$ ?

iv. Why didn't you choose $c$ ?

v. What does "ecosystem" mean to you?

1. Can you give me an example?

"Ecosystem...it is mainly all, it's kind of like everything that an organism needs to live. Kind of like any kind of animal, like a tiger could eat some other animal and that gets energy from that and it also needs water...and the soil helps the plants and the weather helps the soil. So it all works out to food...or energy...to an animal or organisms."

vi. What does "community" mean to you?

1. Can you give me an example? 
"It's kind of...It's not like an ecosystem because an ecosystem is all... like energy, the soil, water, and weather and all of them.

But a community of organisms...it's just a couple of animals, like families in one part and then another family in another part of the forest. Kind of like Crystal Falls in a way."

vii. What does "biotic and abiotic" mean to you?

1. Can you give me an example?

"Biotic is an organism that was living or once-living. Abiotic is a organism that has died, like say a deer was crossing a road and car hit it, and it was lying there on the ground, then for a couple of minutes, or maybe like for like a day or two, it would still be biotic because it was living or once-living. But then when the carcass goes away, then it would be abiotic.

3. Provide student with six words (osprey, trout, minnow, caddisfly, phytoplankton, algae, crayfish) related to food chain (written in big letters on separate 1 " $\times 2$ " slips of paper).

a. Ask student to arrange the words on a piece of paper and draw lines to show words that are related.

(Sun) algae $\rightarrow$ phytoplankton $\rightarrow$ caddisfly $\rightarrow$ minnow $\rightarrow$ crayfish $\rightarrow$ trout $\rightarrow$ osprey

b. Ask the following questions:

i. What does "food chain" mean to you?

"Food chain is kind of like a food source to whatever is the predator or prey; both of them have energy to me, and both of them are food, or they can eat food easily. It kind of like a chain that can go around and around...and possibly never stop."

ii. What does "energy transfer" mean to you?

1. Can you give me an example from your arrangement of the words?

"Energy transfer, well like the one we did in our journal. It was like a hawk and then a bird then a snake...well if it was in water the algae would be the decomposer so it would clean up...if one of these died it mainly would eat up all of them, and then if it would keep going around. It keeps passing. Energy transfer mainly the algae can to anyone of these, the plankton can go to anyone of these. But the caddisfly, minnow, crayfish, trout, and osprey can go to the plankton and kind of eat it. So the energy keeps passing on."

iii. What does "producer" mean to you?

1. Can you give me an example?

"A producer to me would be like a grass type...or a plant-type. Because it produces the sunlight...it produces all the sunlight that comes into it and lets it grow."

iv. What does "consumer" mean to you?

1. Can you give me an example? 
"A consumer is kind of like the opposite of producer...it like eats what, like maybe if we are saying a deer, it would eat the producer that absorbs the sun."

v. What does "decomposer" mean to you?

1. Can you give me an example?

"When I think of that, I kind of think of a bear, sometimes. And when I think of a bear, I kind of think of bacteria in its mouth kind of spreads along the like maybe the deer, and it might spread around and eat it a little. It kind of like eats, or sometimes it can give diseases out, like carcasses, so nothing might want to eat it, and nothing will, it might just like disintegrate into the ground."

vi. What does "competition" mean to you?

1. Can you give me an example?

"Competition means like...say there are two species like a lion and a cheetah both see a dead...like a small rat maybe. Like they both go for it, but there's only one, so they have to kind of fight. And it kind of goes to like kind of death.

vii. What does "parasitism" mean to you?

1. Can you give me an example?

"It's a parasite...the difference between a parasite and a predator is that the predator likes to eat it really fast and get over it, but the parasite like say it was on a trout, it like holds onto it for a long time and sucks the blood out, like really really slowly. It is like smaller and it wants to get some blood out."

viii. What does "symbiosis" mean to you?

1. Can you give me an example?

"Umm...symbiosis to me is like kind of like something helps out another, say like a tree and a human. The tree helps the human because the tree gives off $\mathrm{O}_{2}$ and the human needs $\mathrm{O}_{2}$. But the human gives off $\mathrm{CO}_{2}$ and the trees need it, so it kind of works out both ways."

ix. What does "predator/prey" mean to you?

1. Can you give me an example?

"Kind of like a fox and a beaver, kind of. The fox would be the predator and the beaver would be the prey." 


\section{JG - Experimental \\ Clinical interview}

Logistics

Students will be interviewed individually. The student and I will be sitting opposite each other (facing each other) at a table. I will start with something in front of the student that I will ask them to read aloud, describe or tell me about.

\section{Ecology}

1. Ask the student to read aloud item \#46 (see below) from the pre/post test (in large print on a card).

46. Sustainability is described as:

a. the study of diversity in ecology.

b. the ability to fulfill your own personal needs, without regards to the overall human population and its future.

c. giving up all material belongings.

d. the ability to fulfill human needs in a way that allows the human population to survive indefinitely.

a. Ask student the following questions:

i. What would you choose as the correct answer?

1. Why?

"I think it's D. Because when we're working... when you gave us this one sheet of paper, I remember for our 'footprint,' it said something about the ability, like how to choose your needs. I believe it said the materials will help you and save energy and water."

ii. Why didn't you choose a (if student chose d)?

"Because it's kinda (sic) of like the study of it, and I don't think that's right."

iii. Why didn't you choose $b$ ?

"Well I was in between these two (d), but this one is the population of it and the future."

iv. Why didn't you choose $c$ ?

"Because it like giving up all, when you are just gaining good ones."

v. What does "sustainability" mean to you?

1. Can you give me an example?

"Like good materials. Like a good shower head...low-flow.

vi. What does "ecology" mean to you?

1. Can you give me an example?

"It means like...umm...like the whole unit we're working on is

like ecology. It's like studying that. We looked at our footprints, we looked at animals like the trout and how the food chain and all of that works."

vii. What does "diversity" mean to you?

1. Can you give me an example? 
"Umm...I think it means...every time I look at that one it almost seems like divide for me."

viii. What does "population" mean to you?

1. Can you give me an example?

"Like the population of humans or animals. There's like a population of humans in the school right now. It's like a group of humans or animals in a school or in the wild."

2. Ask the student to read aloud item \#11 (see below) from the pre/post test (in large print on a card).

11. An ecosystem consists of
a. a community of organisms.
b. energy.
c. the soil, water, and weather.
d. all of the above.

a. Ask student the following questions:

i. What would you choose as the correct answer?

1. Why?

"I think it's D. Because there are organisms in an ecosystem.

The organisms need energy and they burn energy in an ecosystem. And in order to survive, they need soil, water, and weather."

ii. Why didn't you choose a (if student chose $d$ )?

"They need everything."

iii. Why didn't you choose $b$ ?

"They need everything."

iv. Why didn't you choose $c$ ?

"They need everything."

v. What does "ecosystem" mean to you?

1. Can you give me an example?

"A family of organisms. Umm...like a group or habitat of animals and how it works. We looked at a beach with an ocean and a pond and birds, a beach ecosystem (from the posters)."

vi. What does "community" mean to you?

1. Can you give me an example?

"I think it means like a community of people...like a family. People."

vii. What does "biotic and abiotic" mean to you?

1. Can you give me an example?

"Abiotic means non-living and biotic means living. Abiotic: a stone; biotic: a trout.

3. Provide student with six words (osprey, trout, minnow, caddisfly, phytoplankton, algae, crayfish) related to food chain (written in big letters on separate 1 " $\times 2$ " slips of paper).

a. Ask student to arrange the words on a piece of paper and draw lines to show words that are related.

algae $\rightarrow$ phytoplankton $\rightarrow$ caddisfly $\rightarrow$ crayfish $\rightarrow$ minnow $\rightarrow$ trout $\rightarrow$ osprey

b. Ask the following questions: 
i. What does "food chain" mean to you?

"A food chain, like it means, like there's energy from one like algae to plankton, and then the plankton gets energy from algae, and then the caddisfly eats the plankton and keeps going on and on."

ii. What does "energy transfer" mean to you?

1. Can you give me an example from your arrangement of the words?

"Energy, like the nutrients, passed on. Energy from each gets passed on from organism to the next (lists organisms in food chain).

iii. What does "producer" mean to you?

1. Can you give me an example?

"It means a plant like algae. It gets its...it grows from the sun."

iv. What does "consumer" mean to you?

1. Can you give me an example?

"It means like it consumes the next animal or bug. Osprey consumes a trout."

v. What does "decomposer" mean to you?

1. Can you give me an example?

"A decomposer is something that breaks down the energy. Fungus."

vi. What does "competition" mean to you?

1. Can you give me an example?

"There's two animals, like the same kind are competing to eat the same kind of food. A minnow and a minnow competing over food."

vii. What does "parasitism" mean to you?

1. Can you give me an example?

"It means like a tick...it like goes on you but it doesn't want to kill you because it wants to stay on you as long as it can. A tick on a person."

viii. What does "symbiosis" mean to you?

1. Can you give me an example?

"I don't know, I forgot."

ix. What does "predator/prey" mean to you?

1. Can you give me an example?

"The wolf and moose...predator and prey. The prey is the moose, the predator is the wolf. The wolf is trying to like kill the moose because it needs food. The moose keeps trying to get away." 
This page deliberately blank 
Appendix M. Photographs (taken by Ziegler) of Trout Setup in Classroom and Trout Release in Local Lake

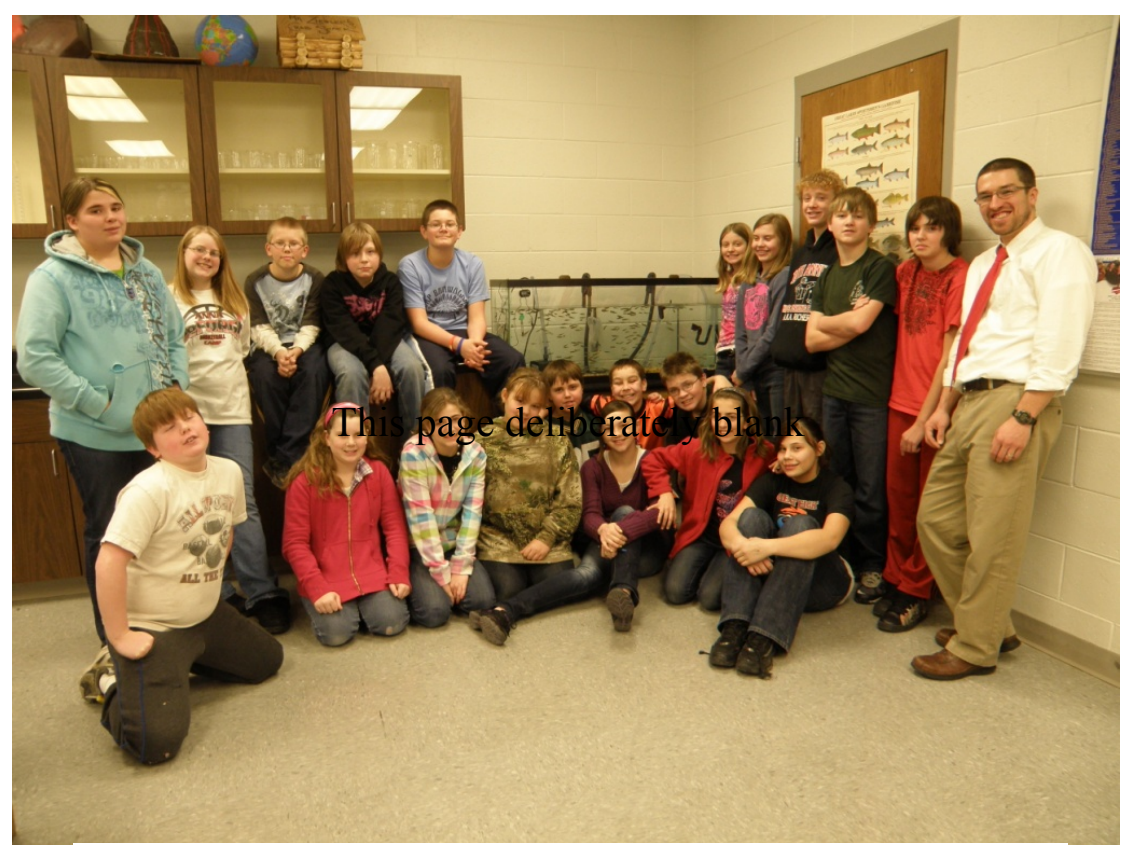

Sixth grade students in front of trout rearing equipment.

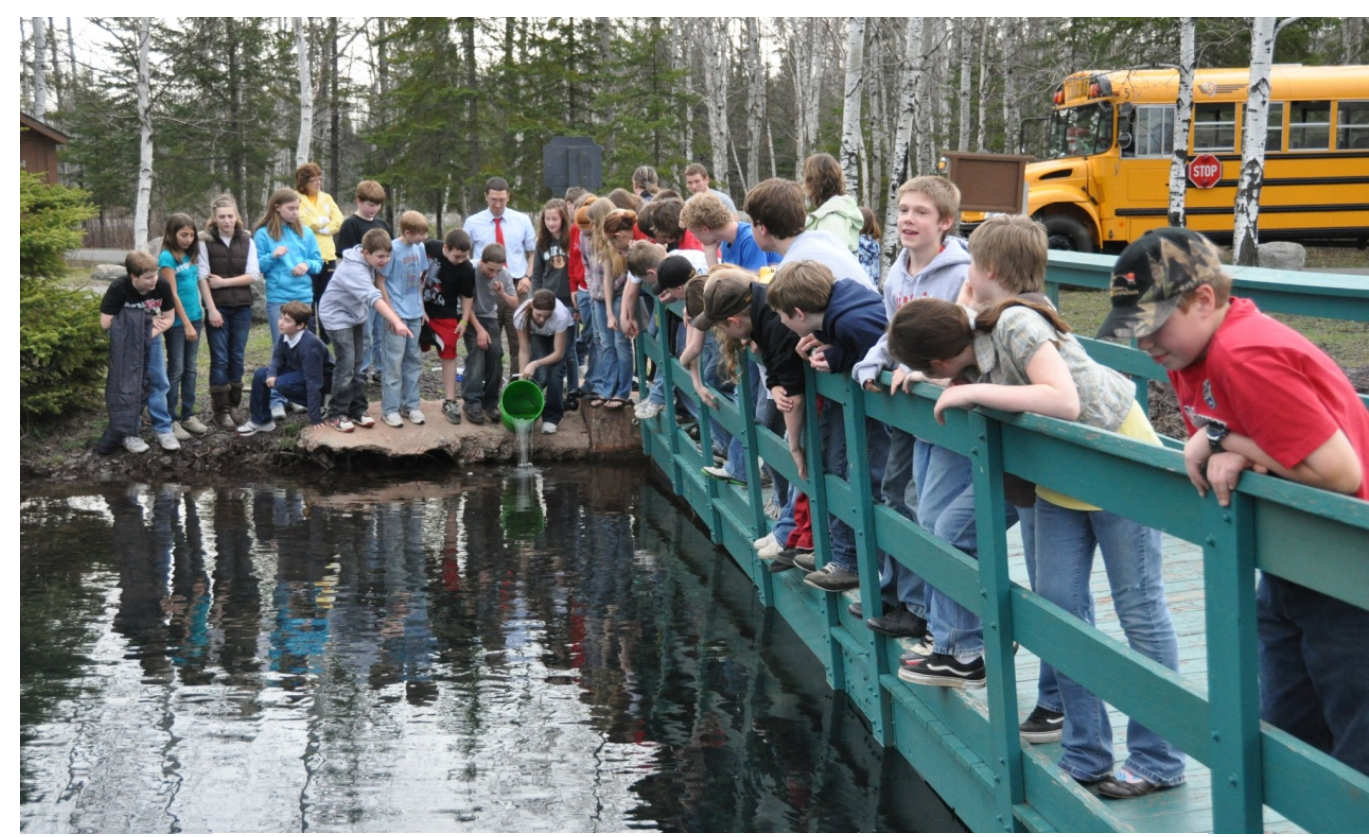

Sixth grade students releasing trout into local lake. 
This page deliberately blank 


\section{Appendix N. Institutional Review Board Forms}

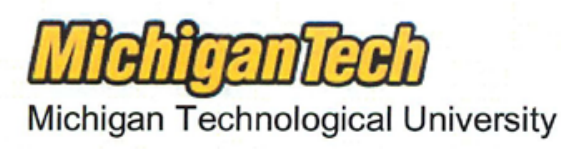

\author{
Office of Research Integrity \\ and Compliance
}

\begin{tabular}{rr} 
Lakeshore Center \\
1400 Townsend Drive \\
Houghton, MI 49931 \\
906.487 .2902 \\
\hline
\end{tabular}

\section{MEMO}

TO: Dr. William Yarroch, CLS

CC: Erich Ziegler, CLS

FROM: Joanne Polzien, Director Research Integrity and Compliance

DATE: November 1, 2010

SUBJECT: Approval M0662

Your application to use human subjects in research or classroom situations has been reviewed with the following determination:

Protocol \#: M0662

Protocol Title: "Relevant Learning and the Effects on Deep Knowledge in a Rural Upper Peninsula of Michigan Classroom"

Approved Dates: November 1, 2010 through October 31, 2011.

Approvals are granted for up to a one year period. You will need to request a continuation for each year of the project six weeks prior to the end date indicated above for each year of the project. The Office of Research Integrity and Compliance will make every effort to send the Principal Investigator annual reminders. However, the Principal Investigator is responsible for submitting annual Continuation Forms in advance of the expiration date for the project. It is very important that these expiration dates are not missed. Failure to submit annual review materials on time will result in the termination of this protocol.

This approval applies only for this project, and only under the conditions and procedures described in the application; if any changes are made in the protocol or conditions set forth in the application, the principal investigator must obtain a separate approval before these changes take place. The approved project will be subject to surveillance procedures requiring periodic review. This review will consist of consulting with the principal investigator and examining the appropriate project records.

Individual identification of human subjects in any publication is an invasion of privacy. Before beginning a project involving human subjects, and only if required, the principal investigator must obtain a properly executed informed consent from each subject and/or the person legally responsible for the subject. If a consent form has been reviewed and approved it has been attached with an official date stamp on it. Only copies of the official date stamped informed consent is to be distributed to participants relating to this project. If any changes or modifications are needed regarding this form, you must first submit the revised document for review and approval prior to use. The principal investigator must retain informed consent forms on file for at least three years after the end of the project. If a project involves a high level of risk, copies of the signed informed consent forms must be filed with the Human Subjects Committee; if this is the case, you will be notified.

This document is on file in the Office of Research Integrity and Compliance. If you have any questions, please contact me at 487-2902 or jpolzien@mtu.edu. 


\section{High School Middle School}

801 Forest Parkway Crystal Falls, MI 49920

Phone: 906-875-6869

Fax: 906-875-4660 www fptrojans.org

K.12 Principal:

Becky Taylor

906-875-3131

Counselor:

Harold Payne

906-875-2125
Consent to Participate in Research

Real-world Issues Study

1. My name is Mr. Erich Ziegler. I am working on a Master's Degree in Applied Science from Michigan Technological University in Houghton, Michigan.

2. My aaivisor, Dr. William Yerroch, and I are asking you to take part in a research study because we are attempting to leam more about the effects of using realworld issues in the science classroom. We will be reariug trout in the classroom and releasing them in a local watershed as our real-world issue, which we will use to better learn and understand ecology.

3. If you agree to be in this study, you will participate in several lessons thet irvolve the use of real-world issues. By participeting in this study you will gair experience in real-worid issues, including the rearing and release of a local organism (trout), which are relevant for both the world of science as well as in your own lives.

4. You will take a pre- and post-test that will contain some questions about your knowledge of this subject and I will use some of your assignments as part of the study. A sub sample of the class will be interviewed by me to better understand what was leamed in the project as well. Your real name will never be used in publication - each of your assessments and assignments will be assigned a random number.

5. Only classroom knowledge relevant to Michigan GLCE/HSCE will be measured both in the tests and in the interviews. We will be focusing on the Life Science standards, specifically those about ecosystems. The Science 6 standards can be found at the following website:

htip:/www.michigan.gov/documents/mde/6-Science COMPLETE 12-10$07.2183217 .0 \mathrm{df}$

6. There are no lcnown risks to participating. We will be using all of the classroom resources and laboratory equipment in a safe, responsible matner.

7. Please talk this over with your parents before you decide whether ar not to participate. Your parents will need to give their permission for you to take part in this study. They can give permission by reading, signing, and having you return the parent conserat form to me. Even if your parents say "yes," you can still declinı to participate.

8. If you decline to participate, there will be no negative consequences. You can change your mind at any time after starting the study by verbally telling Mir. Erich Ziegler.

9. You can ask any question that you have about the study at any time, either in person or at eziegler@fptrojans.org.

10. Signing your name at the bottom and on the following page weans that you agee to be in this study. You and your parents will keep this copy. You will also need to sign the bottom of the parent/student consent forn (see the next page).

Sign and keep this form for your records. Sign and retum the second page to your science teacher.

Signature of Student

Signature of Parent/Guardian

Printed Name of Student

Printed Name of Parent/Guardian

Date

Date

DATE OF IRB APPROVAL: 11.01 .10

RB NUMBER: M0662

PROJECT EXPIRATION DATE: $10 \cdot 31 \cdot 1$ 
Parental Consent - Relevant Learning and the Effects of Deep Knowledge in a Rural Upper Peninsula of Michigan Classroom

Please indicate whether or not you wish to allow your child to participate in this project by checking one of the statements below, signing your name and having your child return this page to me, Mr. Erich Ziegler. Keep the first page for your records.

I grant permission for my child to participate in Erich Ziegler's and William Yarroch's study of Relevant Learning and the Effects of Deep Knowledge in a Rural Upper Peninsula of Michigan Classroom.

I do not grant permission for my child to participate in Erich Ziegler's and William Yarroch's study of Relevant Learning and the Effects of Deep Knowledge in a Rural Upper Peninsula of Michigan Classroom.

Signature of Parent/Guardian

Printed Name of Child

Printed Parent/Guardian Name

Date

\section{Student Consent - Relevant Learning and the Effects of Deep Knowledge in a Rural Upper Peninsula of Michigan Classroom}

I have read and understand the Student Assent to Participate form for Mr. Ziegler's and Dr. Yarroch's real-world applications project. If I have questions, I understand that I can ask them at any time during the classroom unit or I can contact Mr. Ziegler by emailing him at eziegler@fptrojans.org

Please check one of the following, and return this page to Mr. Ziegler. Keep the Assent to Participate form for your records.

I do agree to participate in Mr. Ziegler's and Dr. Yarroch's study of Relevant Learning and the Effects of Deep Knowledge in a Rural Upper Peninsula of Michigan Classroom. I have read and understand the Assent to Participate form, and agree to its terms.

1 do not agree to participate in Mr. Ziegler's and Dr. Yarroch's study of Relevant Learning and the Effects of Deep Knowledge in a Rural Upper Peninsula of Michigan Classroom. I have read and understand the Assent to Participate form, and I do not wish for my class work or scores to be used.

Signature of Subject

Printed Name of Subject

Date

DATE OF IRB APPROVAL: $11-0,-10$

IRB NUMBER:
PROJECT EXPIRATION DATE:
$10-31-11$ 